\title{
5-Alkyl-2-Urea-Substituted Pyridines: Identification of Efficacious Glucokinase Activators with Improved Properties
}

Todd J. Kohn ${ }^{\$} \dagger^{*}$, Xiaohui $\mathrm{Du}^{\dagger} \dagger_{+}^{*}$, SuJen Lai ${ }^{\dagger}$, YuMei Xiong ${ }^{\dagger}$, Renee Komorowski ${ }^{\$}$, Murielle Veniant $^{\$}$, Zice $\mathrm{Fu}^{\dagger}$, Xianyun $\mathrm{Jiao}^{\dagger}$, Vatee Pattaropong ${ }^{\dagger}$, David Chow ${ }^{\dagger}$, Mario Cardozo ${ }^{\dagger}$, Lixia Jin $^{\dagger}$, Marion Conn ${ }^{\dagger}$, Walter E. DeWolf, Jr.", Christopher F. Kraser ${ }^{\#}$, Ronald J. Hinklin ${ }^{\#}$, Mark L. Boys $^{\#}$, Julio C. Medina ${ }^{\dagger}$, Jonathan Houze ${ }^{\dagger}$, Paul Dransfield ${ }^{\dagger}$, Peter Coward $^{\dagger}$

† Amgen Inc, 1120 Veterans Blvd., South San Francisco, CA, 94080

\$ Amgen Inc, One Amgen Center Drive, Thousand Oaks, CA 94080

\# ArrayBiopharma Inc., 3200 Walnut St., Boulder, CO, 80301.

\section{Supporting Information}

In Vitro Glucokinase Assays. The in vitro efficacy of glucokinase activators was assessed in three separate assays: an $\mathrm{EC}_{50}$ assay to evaluate the potency of each compound at a fixed, physiologically relevant concentration of glucose, a variant of this assay run in the presence of $4 \%$ human serum albumin, and a $\mathrm{V}_{\max }$ assay comprising of a glucose dose-response curve at a fixed, near saturating (if possible) concentration of compound to evaluate its effect on the relative $\mathrm{V}_{\mathrm{m}}$ for glucose. For each of these assays, glucokinase activity was estimated by monitoring the increase in absorbance at $340 \mathrm{~nm}$ in a coupled assay system containing $\mathrm{NAD}^{+}$ and glucose 6-phosphate dehydrogenase. Assays were conducted at $30{ }^{\circ} \mathrm{C}$ using a thermostatically controlled absorbance plate reader (Spectramax 340PC, Molecular Devices Corp.) and clear, 96-well, flat bottom, polystyrene plates (Costar 3695, Corning). Each 50- $\mu \mathrm{L}$ assay mixture contained $10 \mathrm{mM} \mathrm{K} \mathrm{K}^{+} \mathrm{MOPS}, \mathrm{pH}$ 7.2, $2 \mathrm{mM} \mathrm{MgCl}_{2}, 50 \mathrm{mM} \mathrm{KCl}, 0.01 \%$ Triton X100, 2\% DMSO, $1 \mathrm{mM}$ DTT, $1 \mathrm{mM}$ ATP, $1 \mathrm{mM} \mathrm{NAD}+5 \mathrm{U} / \mathrm{mL}$ glucose 6-phosphate dehydrogenase, approximately $0.2 \mathrm{nM}$ human glucokinase and (depending on the assay) varying concentrations of glucose and test compound. The absorbance at $340 \mathrm{~nm}$ was monitored 
kinetically over a period of $5 \mathrm{~min}(10 \mathrm{~s} / \mathrm{cycle})$, and rates were estimated from the slopes of linear fits to the raw data.

Glucokinase $\mathbf{E C}_{50}$ Assay. For this assay, the glucose concentration was fixed at $5 \mathrm{mM}$, while the control or test compound was varied over a 10-point, 3-fold dilution series and typically ranged from a high dose of $50 \mu \mathrm{M}$ to a low dose of approximately $2.5 \mathrm{nM}$. A standard, fourparameter logistic model (Equation 1) was fit to the raw data (rate versus concentration of compound):

$$
y=A+\frac{B-A}{1+\left[\frac{C}{x}\right]^{D}}
$$

where $\mathrm{x}$ is the concentration of compound, $\mathrm{y}$ is the estimated rate, $\mathrm{A}$ and $\mathrm{B}$ are the lower and upper asymptotes, respectively, $\mathrm{C}$ is the $\mathrm{EC}_{50}$ and $\mathrm{D}$ is the Hill slope. The $\mathrm{EC}_{50}$ is defined, therefore, as the midpoint or inflection point between the upper and lower asymptotes.

A variant of this assay was run in the presence of $4 \%$ human serum albumin (HSA), the concentration in normal human plasma, in order to obtain an immediate assessment of the plasma protein binding potential of the glucokinase activators (GKA's). It also served as a functional readout on activity in the presence of serum protein, given the dynamic nature of plasma protein binding. A low fold-shift in the non-treated versus 4\% HSA $\mathrm{EC}_{50}$ 's was considered desirable, since the anticipated higher free fraction of GKA would likely translate into greater efficacy at a lower plasma GKA concentration. This parameter was calculated from the ratio of the $\mathrm{EC}_{50}$ 's obtained under both conditions [fold-shift $=\mathrm{EC}_{50(4 \% \mathrm{HSA})} \mathrm{EC}_{50(\mathrm{No} \mathrm{HSA})}$ ].

Glucokinase $\mathbf{V}_{\max }$ Assay. For this assay, the concentration of control or test compound was fixed at or near a saturating concentration, while the glucose concentration was varied over a 10point, 2-fold dilution series ranging from 80 to approximately $0.16 \mathrm{mM}$. The same fourparameter logistic model used for the $\mathrm{EC}_{50}$ assay (Equation 1) was employed to estimate the $\mathrm{V}_{\max }$ (upper asymptote) relative to that run in the absence of GKA. In this assay, the definitions for the variables and parameters are similar except that now $\mathrm{x}$ represents the concentration of glucose, $\mathrm{B}$ is the rate at saturating glucose $\left(\mathrm{V}_{\mathrm{m}}\right), \mathrm{C}$ is the $\mathrm{S}_{0.5}$ for glucose (the concentration of glucose at $\mathrm{V}_{\mathrm{m}} / 2$ ) and $\mathrm{D}$ is the Hill Coefficient. 
Oral Glucose Tolerance Test for 7: 8-week old male ob/ob mice (The Jackson Lab) were fasted overnight $(\sim 16 \mathrm{hr})$. In the morning following overnight fasting, animals were orally dosed with vehicle or compound (7) $30 \mathrm{~min}$ before an oral glucose load (2 g/kg). Tail vein blood glucose levels were measured at -30, 0, 15, 30, 60, 90, and 120 min using AlphaTRAK glucose strip (Abbott Laboratories). Compound (7) was prepared as a suspension in 0.5\% methylcellulose and $1 \%$ Tween 80 .

Fed Blood Glucose Test for 21 (AM-9074): Male Sprague Dawley rats purchased from Harlan Laboratories at 9 weeks of age were cared for in accordance to the Guide for the Care and Use of Laboratory Animals, $8^{\text {th }}$ Edition. Animals were pair-housed at an AAALAC, Intl- accredited facility in non-sterile ventilated micro-isolator housing on corn cob bedding. All research protocols were approved by the Institutional Animal Care and Use Committee.

Animals had ad libitum access to pelleted feed (Harlan Teklad, 2020x) and water (reverse osmosis-purified) via an automatic watering system. Animals were maintained on a 12:12 hr light: dark cycle $(6: 30 \mathrm{am}-6: 30 \mathrm{pm})$ in rooms with temperature set at $72^{\circ} \mathrm{F}\left(69.5-74.5^{\circ} \mathrm{F}\right.$ range $)$ and humidity set at 50\% (30-70\% range) and had access to enrichment opportunities.

Animals were allowed to acclimate to the facility for one week prior to experiment and were acclimated to handling a few days before experiment. The day of the experiment, fed blood glucose levels were measured at 9:00 AM. Animals were then randomized into five groups based on fed blood glucose levels and were orally dosed with either vehicle or AM-9074 at 3,10, 30 or $100 \mathrm{mg} / \mathrm{kg}$ of body weight. Fed blood glucose levels were measured at 0.5, 1.5, 3 and 5 hours post oral dose of vehicle or compound. After the five hour glucose measurement, a terminal blood sample was collected for drug exposure determination. Food was available during the entire experiment. Animals were consciously bled via lateral tail vein for all time points and an Alpha TRAK held glucometer from Abbot Laboratories was used to measure glucose levels.

Abbreviations of the solvents and reagents: $\mathrm{CDCl}_{3}$, deuterochloroform; EtOAc, ethyl acetate; $\mathrm{MeOH}$, methanol; EtOH, ethanol; iPrOH, 2-propanol; DMF, N,N-dimethylformamide; DMSO, 
dimethyl sulfoxide; THF, tetrahydrofuran; $\mathrm{Et}_{2} \mathrm{O}$, diethyl ether; DME, 1,2-dimethoxyethane; ACN or $\mathrm{CH}_{3} \mathrm{CN}$, acetonitrile; DCM or $\mathrm{CH}_{2} \mathrm{Cl}_{2}$, dichloromethane; $\mathrm{LiOH}$, Lithium hydroxide; $\mathrm{NaHCO}_{3}$, sodium hydrogen carbonate; $\mathrm{MgSO}_{4}$, magnesium sulfate; $\mathrm{NaCl}$, sodium chloride; $\mathrm{K}_{2} \mathrm{CO}_{3}$, potassium carbonate; $\mathrm{KF}$, potassium fluoride; $\mathrm{Cs}_{2} \mathrm{CO}_{3}$, cesium carbonate; DMAP, 4dimethylaminopyridine; TBAF, tetrabutylammonium fluoride; $\mathrm{Et}_{3} \mathrm{~N}$ or TEA, triethylamine; $\mathrm{HCl}$, hydrochloric acid; $\mathrm{AcOH}$, acetic acid; NBS, N-bromosuccinimide; $\mathrm{NaOH}$, sodium hydroxide; TBS: tert-butyldimethylsilyl; $\mathrm{CHCl}_{3}$ : chloroform; NMP: N-methylpyrrolidone.

General Chemistry. Commercial reagents and anhydrous solvents were used without further purification. Analytical thin layer chromatography (TLC) was performed on Merck silica gel 60 (230-400 mesh). Removal of solvents was conducted by using a rotary evaporator, and residual solvent was removed from nonvolatile compounds using a vacuum manifold maintained at approximately 1 Torr. All yields reported are isolated yields. Product purification by flash chromatography was performed using Teledyne-ISCO Redisep normal phase silica gel columns on a Teledyne-ISCO Companion; or by preparative reversed-phase high pressure liquid chromatography (RP-HPLC) using an Agilent 1100 Series HPLC and Phenomenex Gemini C18 column (5 micron, $100 \mathrm{~mm} \times 30 \mathrm{~mm}$ i.d.), eluting with a binary solvent system A and B using a gradient elution [A: $\mathrm{H}_{2} \mathrm{O}$ with $0.1 \%$ trifluoroacetic acid (TFA); $\mathrm{B}: \mathrm{CH}_{3} \mathrm{CN}$ with $0.1 \%$ TFA] with $\mathrm{UV}$ detection at $220 \mathrm{~nm}$. Low-resolution mass spectral (MS) data were determined on an Agilent 1200 series LC connected to an Agilent 6140 quadrupole MS analyzer (ESI). ${ }^{1} \mathrm{H}$ NMR spectra were obtained on a Bruker Advance II $400(400 \mathrm{MHz})$ or $500(500 \mathrm{MHz})$ spectrometer. Chemical shifts $(\delta)$ are reported in parts per million (ppm) relative to residual undeuterated solvent as an internal reference. The following abbreviations were used to explain the multiplicities: $\mathrm{s}=$ singlet; $\mathrm{d}=$ doublet, $\mathrm{t}=$ triplet, $\mathrm{q}=$ quartet, $\mathrm{dd}=$ doublet of doublets, $\mathrm{dt}=$ doublet of triplets, $m=$ multiplet, $b r=$ broad.

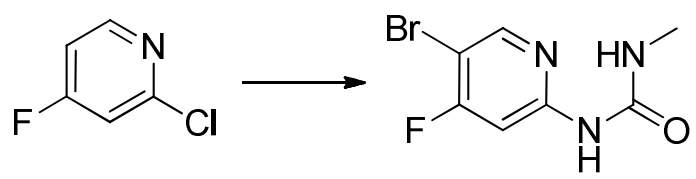


1-(5-Bromo-4-fluoropyridin-2-yl)-3-methylurea (2b): In $30 \mathrm{~mL}$ of $\mathrm{N}_{2}$ sparged (15 min) DME were combined 1-methylurea $(1.70 \mathrm{~g}, 23.0 \mathrm{mmol})$ and finely ground tribasic potassium phosphate $(5.7 \mathrm{~g}, 27 \mathrm{mmol})$ and this slurry was $\mathrm{N}_{2}$ sparged for $5 \mathrm{~min}$ before $\operatorname{Pd}_{2}(\mathrm{dba})_{3}(0.70 \mathrm{~g}$, $0.76 \mathrm{mmol})$ and 1,1'-binaphthyl-2-yldi-tert-butylphosphine (1.20 g, $3.0 \mathrm{mmol})$ were added and the mixture was $\mathrm{N}_{2}$ sparged for another $5 \mathrm{~min}$ before the reaction was heated to $60{ }^{\circ} \mathrm{C}$ for one hour. The reaction was then cooled to room temperature and 2-chloro-4-fluoropyridine (2.1) (2.0 g, $15 \mathrm{mmol}$ ) was added. This mixture was sparged for $1 \mathrm{~min}$ with $\mathrm{N}_{2}$ before the reaction was sealed and heated to $95^{\circ} \mathrm{C}$ overnight. The reaction was diluted with $150 \mathrm{~mL}$ of $1: 1$ $\mathrm{CH}_{2} \mathrm{Cl}_{2}$ :EtOAc then filtered. The cake was washed sequentially with $\mathrm{CH}_{2} \mathrm{Cl}_{2}$ and EtOAc $(\sim 10$ $\mathrm{mL}$ of each) and then discarded. The filtrate was concentrated in vacuo and the resulting residue was purified by chromatography through a silica gel column, eluting with $20 \%$ acetone in $\mathrm{CH}_{2} \mathrm{Cl}_{2}$. Product containing fractions were combined, concentrated in vacuo, and dried under high vacuum to yield 1-(4-fluoropyridin-2-yl)-3-methylurea (1.3 g, $7.6 \mathrm{mmol}, 49 \%$ yield).

In $1.0 \mathrm{~mL}$ of DMF were combined 1-(4-fluoropyridin-2-yl)-3-methylurea (0.10 g, $0.59 \mathrm{mmol})$ and NBS $(0.11 \mathrm{~g}, 0.59 \mathrm{mmol})$ and this was stirred at room temperature overnight. To the reaction was then added $6.0 \mathrm{~mL}$ of water and the suspension was stirred vigorously for $30 \mathrm{~min}$ before the solid was collected via vacuum filtration to afford the title compound (2.2) $(0.11 \mathrm{~g}$, $0.43 \mathrm{mmol}, 72 \%$ yield). MS ESI (pos.) m/e: 247.9, $249.8(\mathrm{M}+\mathrm{H}) .{ }^{1} \mathrm{H} \mathrm{NMR}\left(400 \mathrm{MHz}, \mathrm{CDCl}_{3}\right) \delta$ ppm 9.73 (br. s. $1 \mathrm{H}), 8.85$ (br. s. $1 \mathrm{H}), 8.25$ (d, J=9.2 Hz, $1 \mathrm{H}), 6.78$ (d, J=9.6 Hz, $1 \mathrm{H}), 2.98$ (d, $J=4.7 \mathrm{~Hz}, 3 \mathrm{H})$.

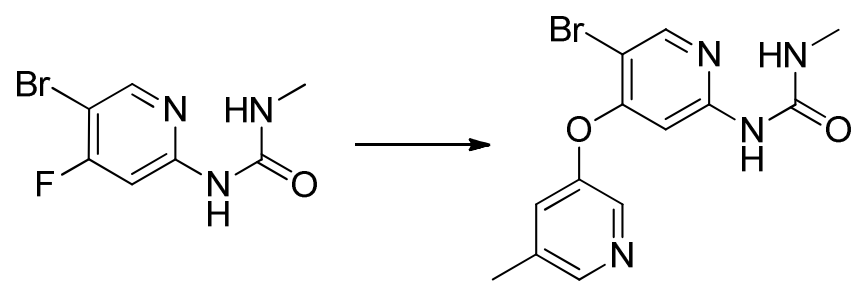

2b $2 c$

1-(5-Bromo-4-((5-methylpyridin-3-yl)oxy)pyridin-2-yl)-3-methylurea (2c). To a 500-mL round-bottomed flask were added 3-hydroxy-5-methylpyridine (7.2 g, $64 \mathrm{mmol})$, cesium fluoride (15.0 g, $96.0 \mathrm{mmol})$ and compound $2.2(16.0 \mathrm{~g}, 64.0 \mathrm{mmol})$ in $\mathrm{CH}_{3} \mathrm{CN}(320 \mathrm{~mL})$. The reaction was heated at reflux at $80{ }^{\circ} \mathrm{C}$ for $16 \mathrm{~h}$. The reaction was cooled to room temperature, 
concentrated and diluted with water. The white precipitate was filtered, collected and dried under reduced pressure to give the title compound (2c) (20.0 g, $61.0 \mathrm{mmol}, 94 \%$ yield) as a white solid. MS ESI (pos.) m/e: 336.9, $339.0(\mathrm{M}+\mathrm{H}) .{ }^{1} \mathrm{H} \mathrm{NMR}\left(400 \mathrm{MHz}, \mathrm{CDCl}_{3}\right) \delta \mathrm{ppm} 8.39(\mathrm{~s}, 1$ H), $8.30(\mathrm{~s}, 1 \mathrm{H}), 8.24(\mathrm{~s}, 1 \mathrm{H}), 8.07(\mathrm{~s}, 1 \mathrm{H}), 6.08(\mathrm{~s}, 1 \mathrm{H}), 2.83(\mathrm{~d}, J=4.7 \mathrm{~Hz}, 3 \mathrm{H}), 2.41(\mathrm{~s}, 3$ $\mathrm{H})$.<smiles>CCO/C=C\c1cnc(NC(=O)NC)cc1Oc1cncc(C)c1</smiles>

2c

(Z)-1-(5-(2-Ethoxyvinyl)-4-((5-methylpyridin-3-yl)oxy)pyridin-2-yl)-3-methylurea (2d). To a stirred solution of compound 2.3 (9.8 g, $29 \mathrm{mmol})$, (Z)-tributyl(2-ethoxyvinyl)stannane (11.0 $\mathrm{g}, 32.0 \mathrm{mmol})$ in xylene $(290 \mathrm{~mL})$ was added $\mathrm{Pd}\left(\mathrm{PPh}_{3}\right)_{4}(3.40 \mathrm{~g}, 2.90 \mathrm{mmol})$. The reaction was heated to $110^{\circ} \mathrm{C}$ and stirring continued for $16 \mathrm{~h}$. The organic solvent was removed under reduced pressure. The crude product was purified by medium pressure chromatography through a Redi-Sep pre-packed silica gel column (330 g), eluting with a gradient of $0 \%$ to $5 \% \mathrm{MeOH}$ in $\mathrm{CH}_{2} \mathrm{Cl}_{2}$ to afford the title compound (2d) (8.50 g, $26.0 \mathrm{mmol}, 88 \%$ yield) as yellow solid. MS ESI (pos.) m/e: $329.0(\mathrm{M}+\mathrm{H}) .{ }^{1} \mathrm{H}$ NMR (500 MHz, CD $\left.3 \mathrm{OD}\right) \delta \mathrm{ppm} 8.92(\mathrm{~s}, 1 \mathrm{H}), 8.47$ (s, $\left.1 \mathrm{H}\right)$, 8.24 - 8.44 (m, 2 H), 7.67 (s, $1 \mathrm{H}), 6.70$ (d, J=7.1 Hz, 1H), 5.61 (d, J=7.1 Hz, $1 \mathrm{H}), 4.15$ (d, J=7.1 Hz, 2 H), $2.71-2.89$ (m, 3 H), $2.35-2.54$ (m, 3 H), 1.41 (t, J=7.1 Hz, 3 H).<smiles>CCO/C=C\c1cnc(NC(=O)NC)cc1Oc1cncc(C)c1</smiles> 
of $\mathrm{HCl}(30.0 \mathrm{ml}, 120 \mathrm{mmol})$, then heated at $80^{\circ} \mathrm{C}$ for $1 \mathrm{~h}$. The reaction mixture was cooled to room temperature and partitioned between satd. aqueous solution of $\mathrm{NaHCO}_{3}$ and $\mathrm{DCM}$. The organic extracts were collected, and dried over $\mathrm{MgSO}_{4}$ and concentrated in vacuo to give 1methyl-3-(4-((5-methylpyridin-3-yl)oxy)-5-(2-oxoethyl)pyridin-2-yl)urea quantitatively which was used without further purification.

To a solution of 1-methyl-3-(4-((5-methylpyridin-3-yl)oxy)-5-(2-oxoethyl)pyridin-2-yl)urea $(8.90 \mathrm{~g}, 30.0 \mathrm{mmol})$ in $\mathrm{MeOH}(300 \mathrm{~mL})$ was added sodium borohydride $(2.20 \mathrm{~g}, 59.0 \mathrm{mmol})$. The reaction mixture was stirred at room temperature. After 2 hours, the reaction mixture was concentrated and the crude product was partitioned between EtOAc and $0.1 \mathrm{~N}$ aqueous solution of $\mathrm{NaOH}$. The organic layer was collected, dried over $\mathrm{MgSO}_{4}$ and concentrated in vacuo. The crude product was purified by medium pressure chromatography through a Redi-Sep pre-packed silica gel column (120 g), eluting with a gradient of $0 \%$ to $10 \% \mathrm{MeOH}$ in $\mathrm{CH}_{2} \mathrm{Cl}_{2}$ to afford the title compound (2) (4.80 g, $16.0 \mathrm{mmol}, 54 \%$ yield). MS ESI (pos.) m/e: $302.9(\mathrm{M}+\mathrm{H}) .{ }^{1} \mathrm{H}$ NMR $\left(500 \mathrm{MHz}, \mathrm{CD}_{3} \mathrm{OD}\right) \delta \mathrm{ppm} 8.30-8.39(\mathrm{~m}, 1 \mathrm{H}), 8.25(\mathrm{~d}, J=2.7 \mathrm{~Hz}, 1 \mathrm{H}), 8.09$ (s, $\left.1 \mathrm{H}\right), 7.49$ 7.57 (m, $1 \mathrm{H}), 6.44$ (s, $1 \mathrm{H}), 3.83$ (t, J=6.6 Hz, 2 H), 2.91 (t, $J=6.7 \mathrm{~Hz}, 2 \mathrm{H}), 2.84$ (s, $3 \mathrm{H}), 2.43$ (s, $3 \mathrm{H})$.

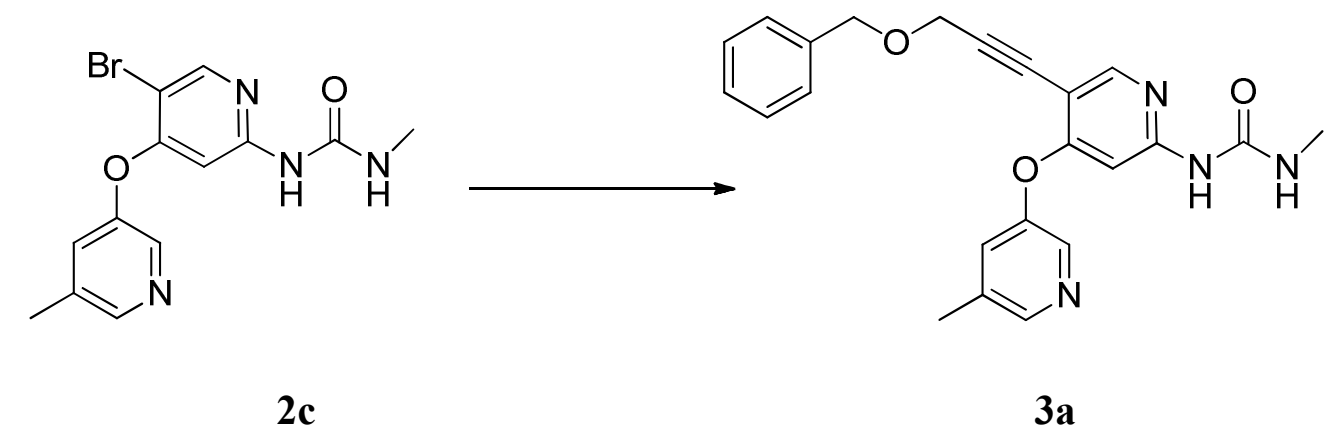

\section{1-(5-(3-(Benzyloxy)prop-1-yn-1-yl)-4-((5-methylpyridin-3-yl)oxy)pyridin-2-yl)-3-}

methylurea (3a). To a flask charged with compound 2.3 ( $0.11 \mathrm{~g}, 0.33 \mathrm{mmol})$, copper (I) iodide $(0.012 \mathrm{~g}, 0.065 \mathrm{mmol})$ and benzyl propargyl ether $(0.24 \mathrm{ml}, 1.60 \mathrm{mmol})$ was added $\mathrm{N}, \mathrm{N}$ diisopropylethylamine $(0.23 \mathrm{~mL}, 1.30 \mathrm{mmol})$. The reaction mixture was purged with nitrogen under high vacuum. Then, degassed DMF $(4.0 \mathrm{ml})$ was added, followed by tetrakis(triphenylphosphine)palladium(0) $(0.038 \mathrm{~g}, 0.033 \mathrm{mmol})$. The reaction was heated to 100 
${ }^{\circ} \mathrm{C}$ for $6 \mathrm{~h}$ then quenched with $2 \mathrm{M}$ aqueous solution of potassium fluoride $(1.0 \mathrm{~mL})$ at room temperature and stirred for $15 \mathrm{~min}$. The crude product was partitioned between EtOAc and water. The organic layer was collected, washed with brine, dried over $\mathrm{MgSO}_{4}$ and concentrated in vacuo. The crude product was purified by reversed phase preparatory HPLC (Gemini ${ }^{\mathrm{TM}}$ Prep $\mathrm{C}_{18} 5 \mu \mathrm{m}$ column; Phenomenex, Torrance, $\mathrm{CA}$; gradient elution of $10 \%$ to $90 \% \mathrm{MeCN}$ in water, where both solvents contain $0.1 \%$ TFA, 30 min method) to provide the title compound (3a) (0.114 g, 0.283 mmol, 87\% yield). MS ESI (pos.) m/e: 403.1 (M+H). ${ }^{1} \mathrm{H}$ NMR (400 MHz, $\left.\mathrm{CDCl}_{3}\right) \delta$ ppm 8.51 (s, $\left.1 \mathrm{H}\right), 8.45$ (br. s., $\left.1 \mathrm{H}\right), 8.07$ (s, $\left.1 \mathrm{H}\right), 7.57$ (s, $\left.1 \mathrm{H}\right), 7.29$-7.47 (m, $6 \mathrm{H}$ ), 4.64 (s, $2 \mathrm{H}), 4.41$ (s, $2 \mathrm{H}), 2.85$ (d, J=4.5 Hz, $3 \mathrm{H}), 2.50$ (s, $3 \mathrm{H})$.

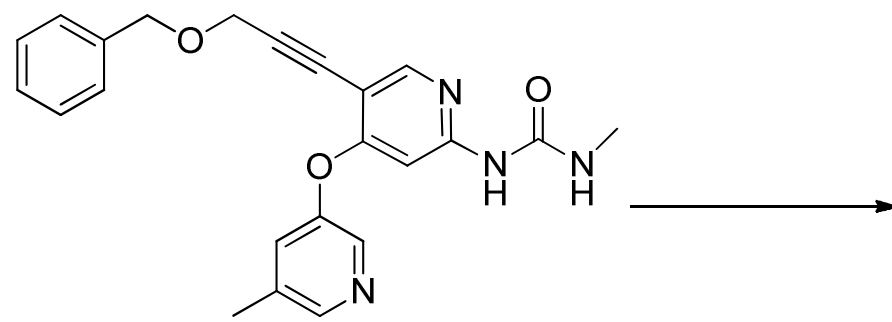

3a

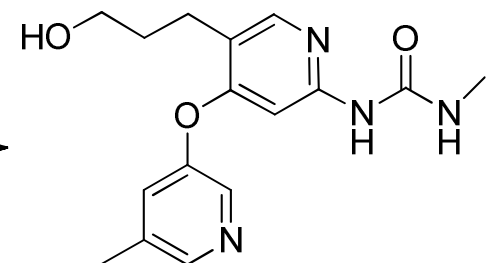

3

1-(5-(3-Hydroxypropyl)-4-((5-methylpyridin-3-yl)oxy)pyridin-2-yl)-3-methylurea (3). To a solution of compound 3.1 (24.0 mg, $0.06 \mathrm{mmol})$ in $\mathrm{MeOH}(20 \mathrm{~mL})$ was added $10 \%$ palladium on carbon $(13.0 \mathrm{mg}, 0.014 \mathrm{mmol})$. The reaction mixture was subjected to three cycles of evacuation and back-filling with hydrogen. The reaction mixture was stirred at room temperature under hydrogen for $18 \mathrm{~h}$. The catalyst was filtered, and the filtrate was concentrated in vacuo. The mixture was purified by reversed phase preparatory HPLC (Gemini ${ }^{\text {TM }}$ Prep $\mathrm{C}_{18} 5 \mu \mathrm{m}$ column; Phenomenex, Torrance, CA; gradient elution of $10 \%$ to $90 \% \mathrm{MeCN}$ in water, where both solvents contain $0.1 \%$ TFA, 30 min method) to provide the title compound as the TFA salt and then neutralized to give the title compound (3) (10.0 mg, $0.033 \mathrm{mmol}$, 53\% yield). MS ESI (pos.) m/e: $317.2(\mathrm{M}+\mathrm{H}) .{ }^{1} \mathrm{H}$ NMR $\left(400 \mathrm{MHz}, \mathrm{CD}_{3} \mathrm{CN}\right) \delta$ ppm 11.68 (br. s, $\left.1 \mathrm{H}\right), 8.55$ (s, $\left.1 \mathrm{H}\right)$, 8.48 (s., 1 H), 7.96 (s, 1 H), 7.85 (s, 1 H), 7.36 (s, 1 H), 6.61 (s, 1 H), 5.44 (s, 1 H), 3.58 (t, $J=6.26 \mathrm{~Hz}, 2 \mathrm{H}), 2.77-2.83$ (m, $2 \mathrm{H}), 2.74$ (d, $J=4.30 \mathrm{~Hz}, 3 \mathrm{H}), 2.48$ (s, $3 \mathrm{H}), 1.80-1.89$ (m, 2 $\mathrm{H})$. 


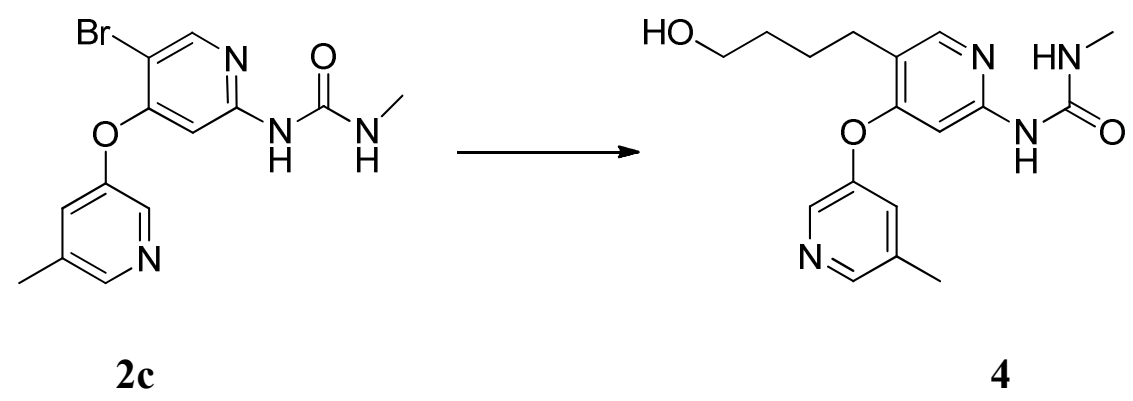

1-(5-(4-Hydroxybutyl)-4-((5-methylpyridin-3-yl)oxy)pyridin-2-yl)-3-methylurea (4).

Synthesized according to the same procedure as compound $\mathbf{3}$ from but-3-yn-1-ol. White solid. MS ESI (pos.) m/e: $331.2(\mathrm{M}+\mathrm{H}) .{ }^{1} \mathrm{H}$ NMR $\left(400 \mathrm{MHz}, \mathrm{CD}_{3} \mathrm{OD}\right) \delta \mathrm{ppm} 8.32(\mathrm{~d}, J=0.98 \mathrm{~Hz}, 1$ H), 8.22 (d, J=2.54 Hz, $1 \mathrm{H}), 8.04$ (s, $1 \mathrm{H}), 7.49$ (s, $1 \mathrm{H}), 6.41$ (s, $1 \mathrm{H}), 3.59$ (t, $J=6.46 \mathrm{~Hz}, 2 \mathrm{H})$, 2.82 (s, $3 \mathrm{H}), 2.70$ (t, J=7.53 Hz, 2 H), 2.41 (s, $3 \mathrm{H}), 1.69$ - 1.81 (m, 2 H), 1.53 - 1.67 (m, $2 \mathrm{H})$.

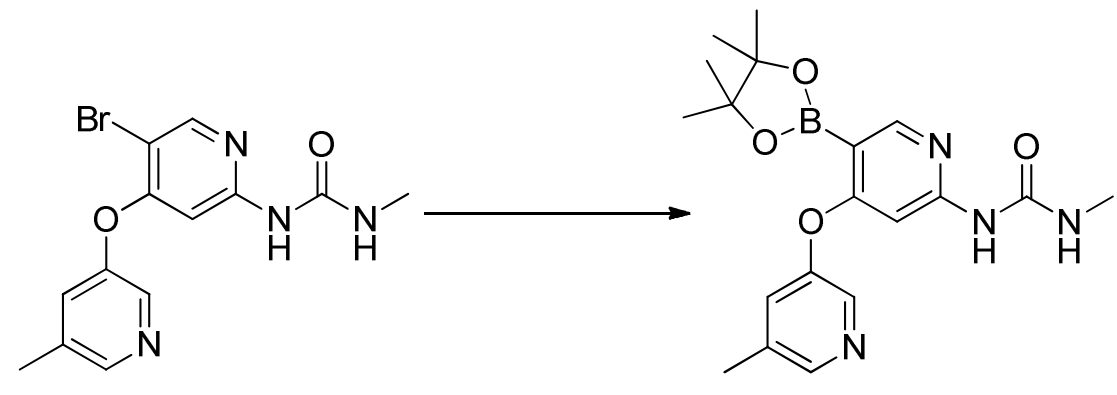

2c

$5 \mathbf{a}$

\section{1-Methyl-3-(4-((5-methylpyridin-3-yl)oxy)-5-(4,4,5,5-tetramethyl-1,3,2-dioxaborolan-2-}

yl)pyridin-2-yl)urea (5a). A mixture of compound $\mathbf{2 c}$, bis(pinacolato)diboron ( $0.57 \mathrm{~g}, 2.22$ $\mathrm{mmol})$, potassium acetate $(0.51 \mathrm{~g}, 5.19 \mathrm{mmol})$ and $\left(1,1^{\prime}-\right.$

bis(diphenylphosphino)ferrocene)dichloropalladium(II) $(0.12 \mathrm{~g}, 0.15 \mathrm{mmol})$ in 1,4-dioxane (5.0 $\mathrm{mL}$ ) was degassed and backfilled with nitrogen. The reaction mixture was stirred at $100{ }^{\circ} \mathrm{C}$ for $18 \mathrm{~h}$. The mixture was cooled to room temperature and concentrated in vacuo. The crude product was purified by medium pressure chromatography through a Redi-Sep pre-packed silica gel column ( $40 \mathrm{~g}$ ), eluting with a gradient of $0 \%$ to $10 \% \mathrm{MeOH}$ in $\mathrm{CH}_{2} \mathrm{Cl}_{2}$ to afford the title compound (5a) ( $0.27 \mathrm{~g}, 0.68 \mathrm{mmol}, 47 \%$ yield) and used directly in the next reactions without further characterization. 


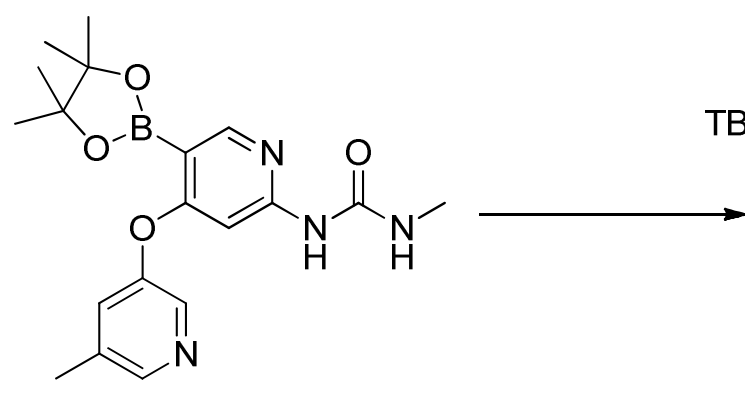

5a<smiles>C=C(CO[R5](C)(=O)O)c1cnc(NC(=O)NC)cc1Oc1cncc(C)c1</smiles>

$\mathbf{5 b}$

\section{1-(5-(3-((tert-Butyldimethylsilyl)oxy)prop-1-en-2-yl)-4-((5-methylpyridin-3-yl)oxy)pyridin-}

2-yl)-3-methylurea (5b). To a stirred suspension of compound 5a (0.44 g, $1.15 \mathrm{mmol})$ in a 4:1 dioxane : water mixture $(11 \mathrm{~mL})$ at room temperature under nitrogen was added tert-butyl(2iodoallyloxy)dimethylsilane ${ }^{\mathrm{i}}(0.34 \mathrm{~g}, 1.20 \mathrm{mmol})$ followed by sodium carbonate $(0.61 \mathrm{~g}, 5.80$ mmol). The mixture was purged with nitrogen for $10 \mathrm{~min}$ then tetrakis(triphenylphosphine)palladium(0) $(0.13 \mathrm{~g}, 0.12 \mathrm{mmol})$ was added. The reaction was heated to $80^{\circ} \mathrm{C}$. After $18 \mathrm{~h}$, the reaction was cooled to room temperature and partitioned between DCM and water. The organic layers were combined, dried over $\mathrm{MgSO}_{4}$, filtered and concentrated. The crude material was purified by medium pressure chromatography through a silica gel column (50 g), eluting with a gradient of $30 \%$ acetone in hexanes, to provide the title compound (5b) (0.32 g, 0.75 mmol, 65\% yield). MS ESI (pos.) m/e: $428.9(\mathrm{M}+\mathrm{H})$. This material was then used directly in the next reactions without further characterization.<smiles>C=C(CO[R15](=O)[O-])c1cnc(NC(=O)NC)cc1Oc1cncc(C)c1</smiles>

$5 \mathbf{b}$<smiles>C=C(CO)c1cnc(NC(=O)NC)cc1Oc1cncc(C)c1</smiles>

5c 


\section{1-(5-(3-Hydroxyprop-1-en-2-yl)-4-((5-methylpyridin-3-yl)oxy)pyridin-2-yl)-3-methylurea}

(5c) To a $25-\mathrm{ml}$ round bottom flask was added compound $5.2(0.20 \mathrm{~g}, 0.47 \mathrm{mmol})$ in THF (1.0 $\mathrm{mL})$ and 1.0 M solution of tetrabutylammonium fluoride in THF $(0.47 \mathrm{~mL}, 0.47 \mathrm{mmol})$. The reaction mixture was stirred at room temperature for $1.5 \mathrm{~h}$. The reaction mixture was diluted with saturated $\mathrm{NH}_{4} \mathrm{Cl}$ solution and extracted with EtOAc. The organic extract was washed with water and dried over $\mathrm{MgSO}_{4}$. The solution was filtered and concentrated in vacuo to give the crude material as a yellow oil. The crude material was absorbed onto a plug of silica gel and purified by medium pressure chromatography through a pre-packed silica gel column (12 g), eluting with a gradient of $0 \%$ to $10 \% \mathrm{MeOH}$ in $\mathrm{CH}_{2} \mathrm{Cl}_{2}$, to provide the title compound (5c) (0.15 g, $0.47 \mathrm{mmol}, 100 \%$ yield) as a white solid. MS ESI (pos.) m/e: $315.1(\mathrm{M}+\mathrm{H}) .{ }^{1} \mathrm{H}$ NMR (500 MHz, CD $\mathrm{CD}_{3} \mathrm{OD} \delta \mathrm{ppm} 8.33(\mathrm{~s}, 1 \mathrm{H}), 8.24(\mathrm{~d}, J=2.4 \mathrm{~Hz}, 1 \mathrm{H}), 8.13(\mathrm{~s}, 1 \mathrm{H}), 7.52(\mathrm{~s}, 1 \mathrm{H}), 6.50$ (s, 1H), $5.51(\mathrm{~d}, J=1.7 \mathrm{~Hz}, 1 \mathrm{H}), 5.23-5.38(\mathrm{~m}, 1 \mathrm{H}), 4.45(\mathrm{~s}, 2 \mathrm{H}), 2.85(\mathrm{~s}, 3 \mathrm{H}), 2.42(\mathrm{~s}, 3 \mathrm{H})$.

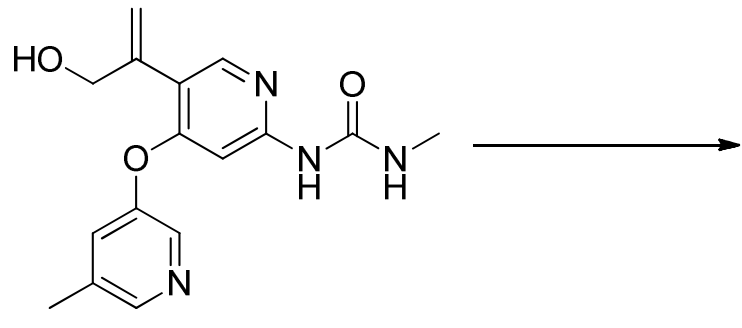

5c

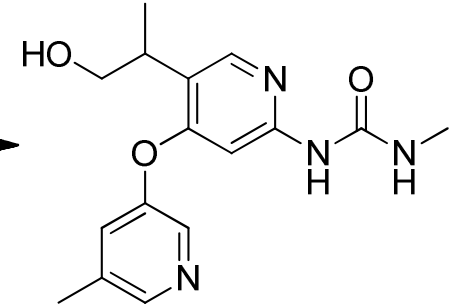

5

\section{1-(5-(1-Hydroxypropan-2-yl)-4-((5-methylpyridin-3-yl)oxy)pyridin-2-yl)-3-methylurea (5).}

To a vial was added compound $\mathbf{5 c}(0.06 \mathrm{~g}, 0.19 \mathrm{mmol}), 10 \%$ palladium on carbon $(0.02 \mathrm{~g}, 0.02$ mmol) and then a 1:1 mixture of EtOH : $\mathrm{MeOH}(4.0 \mathrm{~mL})$. The reaction mixture was purged with hydrogen and stirred at room temperature for three days. The crude material was adsorbed onto a plug of silica gel and purified by chromatography through a pre-packed silica gel column (4 g), eluting with a gradient of $0 \%$ to $10 \% \mathrm{MeOH}$ in $\mathrm{CH}_{2} \mathrm{Cl}_{2}$, to provide the title compound (5) (23 mg, $0.072 \mathrm{mmol}, 38 \%$ yield) as white solid. MS ESI (pos.) m/e: $317.1(\mathrm{M}+\mathrm{H}) .{ }^{1} \mathrm{H}$ NMR (500 $\left.\mathrm{MHz}, \mathrm{CD}_{3} \mathrm{OD}\right) \delta$ ppm $8.31(\mathrm{~s}, 1 \mathrm{H}), 8.23$ (d, J=2.4 Hz, $\left.1 \mathrm{H}\right), 8.10$ (s, $\left.1 \mathrm{H}\right), 7.50$ (s, $\left.1 \mathrm{H}\right), 6.42$ (s, $1 \mathrm{H}), 3.81$ (dd, $J=10.6,6.7 \mathrm{~Hz}, 1 \mathrm{H}), 3.69$ (dd, $J=10.6,6.7 \mathrm{~Hz}, 1 \mathrm{H}), 3.21$ - 3.25 (m, $1 \mathrm{H}), 2.82$ (s, $3 \mathrm{H}), 2.41(\mathrm{~s}, 3 \mathrm{H}), 1.35(\mathrm{~d}, J=7.1 \mathrm{~Hz}, 3 \mathrm{H})$. 


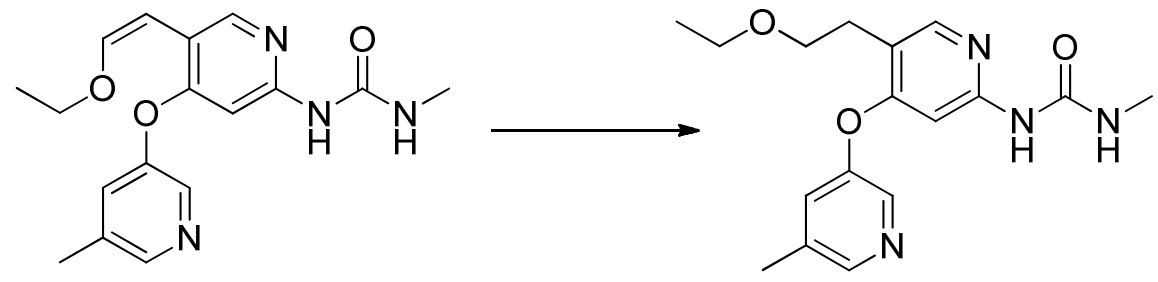

2d

6

\section{1-(5-(2-Ethoxyethyl)-4-((5-methylpyridin-3-yl)oxy)pyridin-2-yl)-3-methylurea (6). To a}

solution of compound $2 \mathrm{~d}(29.0 \mathrm{mg}, 0.091 \mathrm{mmol})$ in $\mathrm{MeOH}(5.0 \mathrm{ml})$ was added $10 \%$ palladium on carbon (9.4 mg, $0.094 \mathrm{mmol})$. The reaction mixture was stirred under balloon pressure hydrogen for $18 \mathrm{~h}$. The crude material was adsorbed onto a plug of silica gel and purified by chromatography through a pre-packed silica gel column $(4 \mathrm{~g})$, eluting with a gradient of $0 \%$ to $2.5 \% \mathrm{MeOH}$ in $\mathrm{CH}_{2} \mathrm{Cl}_{2}$, to provide the title compound (6) (20.0 mg, $0.063 \mathrm{mmol}, 68.5 \%$ yield) as white solid. MS ESI (pos.) m/e: $331.2(\mathrm{M}+\mathrm{H}) .{ }^{1} \mathrm{H}$ NMR $\left(500 \mathrm{MHz}, \mathrm{CD}_{3} \mathrm{OD}\right) \delta \mathrm{ppm} 8.32(\mathrm{~d}$, $J=0.98 \mathrm{~Hz}, 1 \mathrm{H}), 8.22$ (d, $J=2.45 \mathrm{~Hz}, 1 \mathrm{H}), 8.08$ (s, $1 \mathrm{H}) 7.50$ (td, $J=1.65,0.86 \mathrm{~Hz}, 1 \mathrm{H}), 6.43$ (s, $2 \mathrm{H}), 3.70(\mathrm{t}, J=6.72 \mathrm{~Hz}, 3 \mathrm{H}), 3.52$ (q, J=7.09 Hz, $2 \mathrm{H}), 2.93$ (t, J=6.60 Hz, $2 \mathrm{H}), 2.82$ (s, $3 \mathrm{H})$, $2.41(\mathrm{~s}, 3 \mathrm{H}), 1.17(\mathrm{t}, J=7.09 \mathrm{~Hz}, 3 \mathrm{H})$.<smiles>CNC(=O)Nc1cc(Oc2cncc(C)c2)c(Br)cn1</smiles>

2c

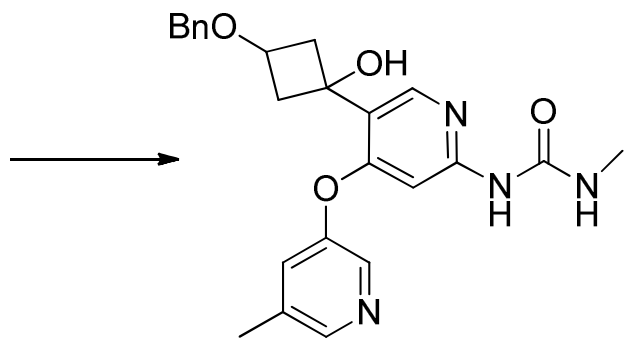

$7 \mathbf{a}$

\section{1-(5-(3-(Benzyloxy)-1-hydroxycyclobutyl)-4-((5-methylpyridin-3-yl)oxy)pyridin-2-yl)-3-}

methylurea 7a: A flask was charged with 1-(5-bromo-4-((5-methylpyridin-3-yl)oxy)pyridin-2yl)-3-methylurea 2c (4.0 g, $12.0 \mathrm{mmol})$ and azeotroped with toluene and purged with nitrogen. 
Then, THF $(130 \mathrm{~mL})$ was added via cannula to the reaction. The reaction mixture was cooled down to $-78^{\circ} \mathrm{C}$ in a dry ice-acetone bath under nitrogen. Methyllithium (1.6M in diethyl ether) $(15 \mathrm{~mL}, 24 \mathrm{mmol})$ was added and reaction was stirred for $10 \mathrm{~min}$, followed by addition of $\mathrm{n}$ butyllithium $(2.5 \mathrm{M}$ in hexanes) $(5.7 \mathrm{~mL}, 14 \mathrm{mmol})$. The reaction was stirred for another $30 \mathrm{~min}$. and then 3-(benzyloxy)cyclobutanone $(3.9 \mathrm{~mL}, 25 \mathrm{mmol})$ was added dropwise at $-78{ }^{\circ} \mathrm{C}$. The reaction was maintained at $-78{ }^{\circ} \mathrm{C}$ for $3 \mathrm{hr}$ and then stirred at room temperature for $5 \mathrm{~min}$. Saturated $\mathrm{NH}_{4} \mathrm{Cl}$ solution was added to quench the reaction. The crude material was extracted with EtOAc. The EtOAc layer was dried over magnesium sulfate, concentrated and purified by chromatography through a pre-packed silica gel column, eluting with a gradient of $0 \%$ to $70 \%$ EtOAc in hexanes, and then gradient $2-8 \% \mathrm{MeOH}$ in DCM to provide desired product. The product fractions were concentrated and a small amount of $\mathrm{MeOH}$ was added. The product 1-(5(3-(benzyloxy)-1-hydroxycyclobutyl)-4-((5-methylpyridin-3-yl)oxy)pyridin-2-yl)-3-methylurea

7a precipitated out of the $\mathrm{MeOH}$ as a white solid (1.3 g, $3.1 \mathrm{mmol}, 26 \%$ ). ESI (pos.) m/e: 435.3 $(\mathrm{M}+\mathrm{H}) .{ }^{1} \mathrm{H}$ NMR $\left(400 \mathrm{MHz}, \mathrm{CD}_{3} \mathrm{OD}\right) \delta \mathrm{ppm} 8.32(\mathrm{~d}, J=0.98 \mathrm{~Hz}, 1 \mathrm{H}) 8.27(\mathrm{~s}, 1 \mathrm{H}) 8.24(\mathrm{~d}$, $J=2.54 \mathrm{~Hz}, 1 \mathrm{H}) 7.52(\mathrm{t}, J=3.65 \mathrm{~Hz}, 1 \mathrm{H}) 7.25-7.36(\mathrm{~m}, 5 \mathrm{H}) 6.43(\mathrm{~s}, 1 \mathrm{H}) 4.46(\mathrm{~s}, 2 \mathrm{H}) 3.78$ (quin, $J=6.94 \mathrm{~Hz}, 1 \mathrm{H}) 3.16-3.24(\mathrm{~m}, 2 \mathrm{H}) 2.82(\mathrm{~s}, 3 \mathrm{H}) 2.38-2.45(\mathrm{~m}, 5 \mathrm{H})$

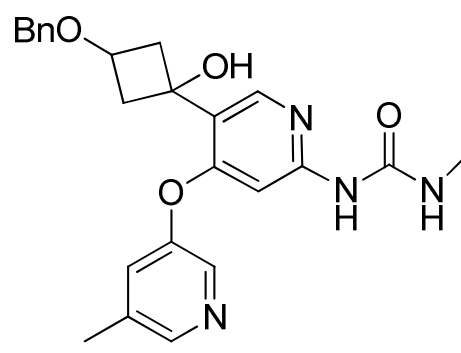

$7 \mathbf{a}$

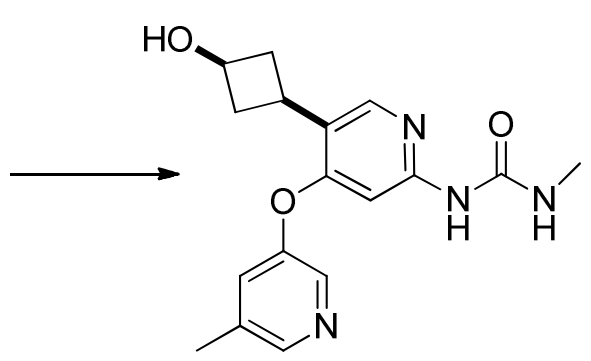

7

\section{1-(5-((1R,3R)-3-Hydroxycyclobutyl)-4-((5-methylpyridin-3-yl)oxy)pyridin-2-yl)-3-}

methylurea 7: A flask was charged with 1-(5-(3-(benzyloxy)-1-hydroxycyclobutyl)-4-((5methylpyridin-3-yl)oxy)pyridin-2-yl)-3-methylurea 7a (4.3 g, $9.9 \mathrm{mmol})$. EtOH (70 mL) and $\mathrm{MeOH}(65 \mathrm{~mL})$ were added followed by methanesulfonic acid $(14 \mathrm{~mL}, 220 \mathrm{mmol})$. The starting material was dissolved upon addition of methanesulfonic acid. 10\% palladium on carbon (2.1 g, $2.0 \mathrm{mmol}$ ) was added. Then the reaction was purged with hydrogen by bubbling in hydrogen gas for $6 \mathrm{~min}$. and then stirred under a double-layered balloon with hydrogen. After overnight stirring, an additional $0.8 \mathrm{~mL}$ of methanesulfonic acid and $200 \mathrm{mg} 10 \% \mathrm{Pd}$ on carbon were added 
and the reaction was hydrogenated again for $20 \mathrm{hr}$ with a fresh hydrogen balloon. After filtering through a pad of diatomaceous earth, the crude mixture was neutralized with aqueous $\mathrm{NaOH}$ to $\mathrm{pH} \sim 8$ and concentrated to remove most of the solvents. EtOAc was added followed by water. The aqueous layer was extracted with EtOAc and the EtOAc layer was dried with $\mathrm{MgSO}_{4}$ overnight. Some product crystallized out. The mixture was filtered and the crystal/ $\mathrm{MgSO}_{4}$ mixture was rinsed with water. The crystals were dried on high vacuum pump to give $0.93 \mathrm{~g}$ of pure product as a white solid. The remaining EtOAc layer was concentrated and purified on a pre-packed silica gel column ( $80 \mathrm{~g})$ with gradient $0-70 \%$ EtOAc in heptanes and then gradient 1$8 \% \mathrm{MeOH}$ in DCM to give $1.58 \mathrm{~g}$ of pure product $1-(5-((1 R, 3 R)-3$-hydroxycyclobutyl)-4-((5methylpyridin-3-yl)oxy)pyridin-2-yl)-3-methylurea 7 . The total amount of product obtained was (2.50 g, 7.6 mmol, 77\%). ESI (pos.) m/e: 329.1 (M+H). HPLC purity: 99\%. ${ }^{1} \mathrm{H}$ NMR (400 MHz, $\left.\mathrm{CD}_{3} \mathrm{OD}\right) \delta \mathrm{ppm} 8.31(\mathrm{~d}, J=0.98 \mathrm{~Hz}, 1 \mathrm{H}) 8.18(\mathrm{~d}, J=2.35 \mathrm{~Hz}, 1 \mathrm{H}) 8.06(\mathrm{~s}, 1 \mathrm{H}) 7.44-7.47$ (m, 1 H) $6.40(\mathrm{~s}, 1 \mathrm{H}) 4.22(\mathrm{tt}, J=8.17,6.70 \mathrm{~Hz}, 1 \mathrm{H}) 3.08-3.18(\mathrm{~m}, 1 \mathrm{H}) 2.82(\mathrm{~s}, 3 \mathrm{H}) 2.68-2.78(\mathrm{~m}$, $2 \mathrm{H}) 2.40(\mathrm{~s}, 3 \mathrm{H}) 1.98-2.13(\mathrm{~m}, 2 \mathrm{H})$. The cis relationship was confirmed by NMR (HSQC, NOESY). See the end of supporting information for detailed NMR data.

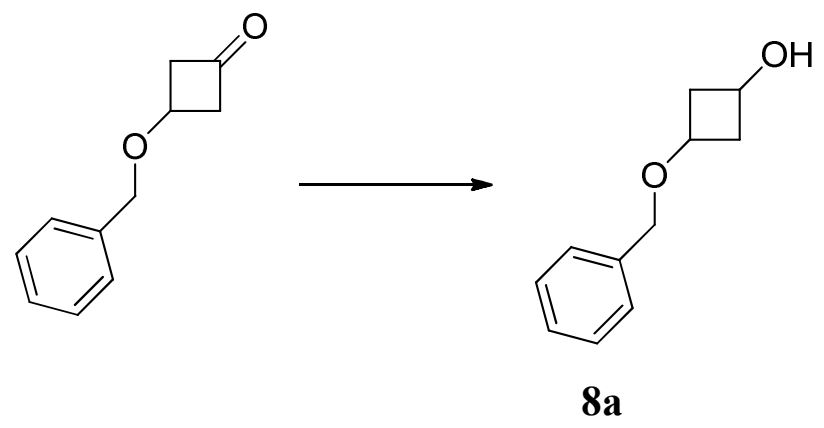

3-(Benzyloxy)cyclobutanol 8.1: A flask was charged with 3-(benzyloxy)cyclobutanone $(1.0 \mathrm{~g}$, $5.7 \mathrm{mmol})$ and $\mathrm{MeOH}(24 \mathrm{~mL})$. Then sodium borohydride $(0.86 \mathrm{~g}, 23 \mathrm{mmol})$ was added. The reaction was stirred for $1.5 \mathrm{hr}$. and saturated $\mathrm{NH}_{4} \mathrm{Cl}$ solution was added. The crude mixture was concentrated in vacuo to remove most of the $\mathrm{MeOH}$ and then water was added, and the reaction was extracted with EtOAc. The EtOAc layer was dried over magnesium sulfate, concentrated and purified on a pre-packed silica gel column to provide the desired product ( $880 \mathrm{mg}, 5.1$ mmol, $90 \%$ yield) $8 \mathrm{a}$ as a clear oil. ${ }^{1} \mathrm{H}$ NMR $\left(400 \mathrm{MHz}, \mathrm{CD}_{3} \mathrm{OD}\right) \delta \mathrm{ppm} 7.23-7.36(\mathrm{~m}, 5 \mathrm{H})$ 4.41 (s, 2 H) 3.82 (quin, $J=7.34 \mathrm{~Hz}, 1 \mathrm{H}) 3.64$ (quin, $J=7.04 \mathrm{~Hz}, 1 \mathrm{H}) 2.56-2.71$ (m, $2 \mathrm{H}) 1.81$ $1.91(\mathrm{~m}, 2 \mathrm{H})$ 


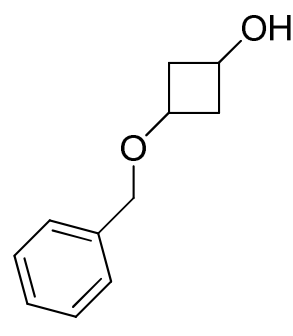

8a

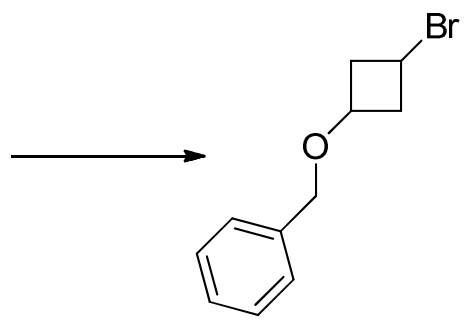

$8 \mathbf{b}$

((3-Bromocyclobutoxy)methyl)benzene 8b: A flask with 3-(benzyloxy)cyclobutanol 8a (720 $\mathrm{mg}, 4.1 \mathrm{mmol})$ was azeotroped with toluene. Carbon tetrabromide (3.4 g, $10 \mathrm{mmol})$ was added followed by $16.0 \mathrm{~mL}$ of DCM, and triethylamine $(1.3 \mathrm{ml}, 9.3 \mathrm{mmol})$. Then, a $9.0 \mathrm{~mL} \mathrm{DCM}$ solution of triphenylphosphine $(2.6 \mathrm{~g}, 9.7 \mathrm{mmol})$ was added dropwise at room temperature. The reaction was heated to reflux for $4.5 \mathrm{hr}$ then stirred at room temperature overnight. The reaction was diluted with pentane and ice-cold half-saturated $\mathrm{NaHCO}_{3}$ solution was added. A small amount of ether was also added. The organic layer was separated, dried over magnesium sulfate, concentrated and purified on a pre-packed silica gel column with gradient $0-30 \%$ EtOAc in hexanes to provide (910 $\mathrm{mg}, 3.8 \mathrm{mmol}, 93 \%$ yield) of ((3-bromocyclobutoxy)methyl)benzene 8b. ${ }^{1} \mathrm{H}$ NMR (400 MHz, $\left.\mathrm{CDCl}_{3}\right) \delta$ ppm 7.27 - 7.39 (m, 5 H) 4.48 - 4.57 (m, 2 H) 4.43 (s, 2 H) $2.62-2.77(\mathrm{~m}, 4 \mathrm{H})$

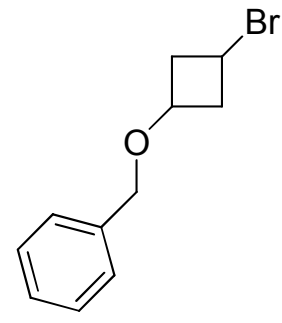

8b

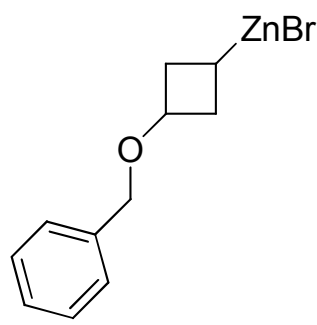

8c

(3-(Benzyloxy)cyclobutyl)zinc (II) bromide 8c: A flask was charged with lithium chloride (140 mg, $3.3 \mathrm{mmol}$ ) and dried under high vacuum at $155^{\circ} \mathrm{C}$ for $30 \mathrm{~min}$. . Then, zinc dust (240 $\mathrm{mg}, 3.6 \mathrm{mmol}$ ) was added and the flask was dried again under high vacuum for $20 \mathrm{~min}$ at 155 ${ }^{\circ} \mathrm{C}$. Anhydrous THF was then added $(6.0 \mathrm{~mL})$ under nitrogen followed by 1,2-dibromoethane $(14.0 \mu \mathrm{L}, 0.16 \mathrm{mmol})$. The flask was heated to $65^{\circ} \mathrm{C}$ with a heat gun briefly and cooled down and then added chlorotrimethylsilane $(4.2 \mu 1,0.033 \mathrm{mmol})$, stirred briefly and 5 drops of $1 \mathrm{M}$ solution of iodine in THF was added. Again, stirred briefly and ((3- 
bromocyclobutoxy)methyl)benzene $\mathbf{8 b}$ (790 $\mathrm{mg}, 3.3 \mathrm{mmol}$ ) in $1 \mathrm{~mL}$ THF was added at room temperature. The mixture was heated to $50{ }^{\circ} \mathrm{C}$ and stirred overnight. The residual zinc dust was allowed to settle to the bottom of the flask. The crude THF solution containing (3(benzyloxy)cyclobutyl)zinc(II) bromide 8c was then used directly in next step.

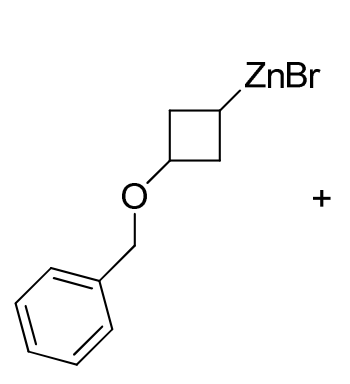

$8 \mathbf{c}$<smiles>CNC(=O)Nc1cc(Oc2cncc(C)c2)c(Br)cn1</smiles>

2c

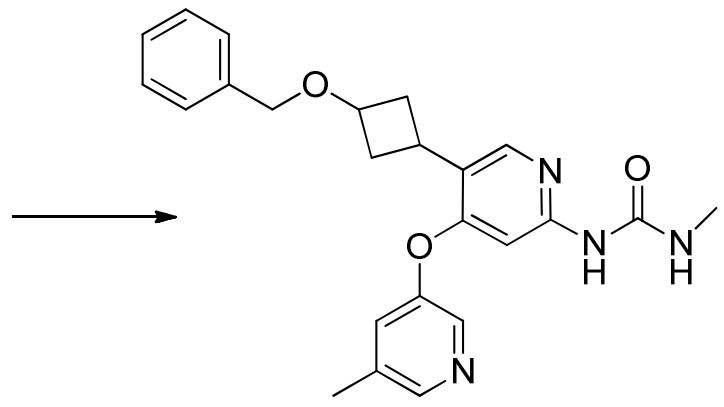

8d

1-(5-(3-(Benzyloxy)cyclobutyl)-4-((5-methylpyridin-3-yl)oxy)pyridin-2-yl)-3-methylurea 8d:

A dried flask containing 1-(5-bromo-4-((5-methylpyridin-3-yl)oxy)pyridin-2-yl)-3-methylurea 2c (250 mg, $0.74 \mathrm{mmol})$, 1,2,3,4,5-pentaphenyl-1-(di-tert-butylphosphino)ferrocene, CTCQPhos (58.0 mg, $0.08 \mathrm{mmol})$, and bis(dibenzylideneacetone)palladium(0) (41 mg, $0.071 \mathrm{mmol})$ was evacuated and backfilled with nitrogen. Argon-degassed THF $(4.0 \mathrm{~mL})$ was added by syringe. After about 2 minutes, the crude THF solution of (3-(benzyloxy)cyclobutyl)zinc(II) bromide $8 \mathrm{c}$ (generated from the above reaction, $5.4 \mathrm{~mL}, 3.0 \mathrm{mmol}$ ) was added dropwise. Upon complete addition of zinc solution, the mixture was heated to reflux. After 19 hours, the reaction was cooled to room temperature, saturated $\mathrm{NH}_{4} \mathrm{Cl}$ solution was added and the mixture was extracted with EtOAc. The EtOAc layer was dried over magnesium sulfate, concentrated and was purified by chromatography through a pre-packed silica gel column, eluting with a gradient of $0 \%$ to $70 \%$ EtOAc in hexanes for $8 \mathrm{~min}$, and then gradient $2-8 \% \mathrm{MeOH}$ in DCM. The resulting impure mixture was purified again on reverse phase $\mathrm{HPLC}\left(0.1 \% \mathrm{TFA}\right.$ in $\mathrm{CH}_{3} \mathrm{CN} /$ water, $10-70 \%$ gradient) to provide (40 $\mathrm{mg}, 0.096 \mathrm{mmol}, 13 \%$ yield) of 1-(5-(3-(benzyloxy)cyclobutyl)4-((5-methylpyridin-3-yl)oxy)pyridin-2-yl)-3-methylurea 8d as a mixture of trans/cis isomer ( $\sim 5: 1$ ratio). ESI (pos.) m/e: $419.1(\mathrm{M}+\mathrm{H})$. 


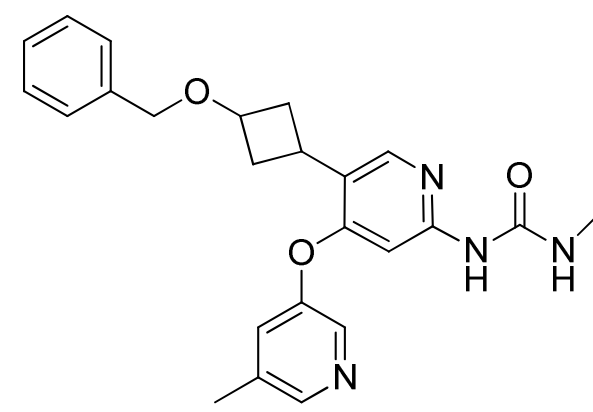

8d

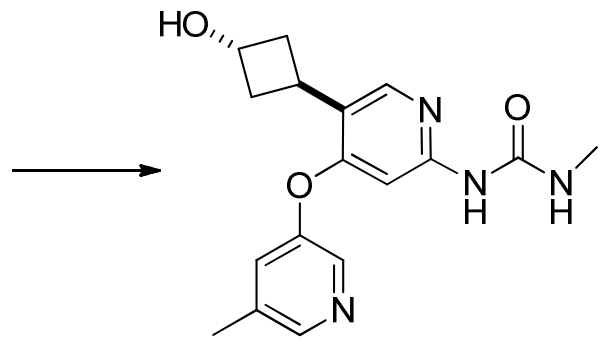

8

\section{1-(5-((1S,3S)-3-Hydroxycyclobutyl)-4-((5-methylpyridin-3-yl)oxy)pyridin-2-yl)-3-}

methylurea 8: A flask was charged with 1-(5-(3-(benzyloxy)cyclobutyl)-4-((5-methylpyridin-3yl)oxy)pyridin-2-yl)-3-methylurea 8d (37 mg, $0.090 \mathrm{mmol})$ and $\mathrm{MeOH}(3.0 \mathrm{~mL})$ was added. Then, $10 \%$ palladium on carbon $(19 \mathrm{mg}, 0.023 \mathrm{mmol})$ was added. The flask was purged with hydrogen and then stirred under a double-layer hydrogen balloon. LCMS indicated no reaction after $7 \mathrm{hr}$. $0.15 \mathrm{~mL}$ of concentrated $\mathrm{H}_{2} \mathrm{SO}_{4}$ was added and hydrogenation was continued overnight. Reaction was completed by LCMS. The crude material was filtered through a pad of diatomaceous earth and neutralized with aqueous $\mathrm{NaOH}$. Then, it was extracted with EtOAc. The organic layer was dried over magnesium sulfate and concentrated to give $22 \mathrm{mg}$ of the crude mixture. The crude product was purified on reverse phase HPLC $\left(0.1 \% \mathrm{TFA}\right.$ in $\mathrm{CH}_{3} \mathrm{CN} /$ water, $10-35 \%$ gradient elution) to give $(9.3 \mathrm{mg}, 0.028 \mathrm{mmol}, 32 \%$ yield) of the trans isomer 1-(5((1s,3s)-3-hydroxycyclobutyl)-4-((5-methylpyridin-3-yl)oxy)pyridin-2-yl)-3-methylurea 8. ESI (pos.) m/e: $329.1(\mathrm{M}+\mathrm{H})$. HPLC purity: 99.6\%. ${ }^{1} \mathrm{H}$ NMR (400 MHz, $\left.\mathrm{CD}_{3} \mathrm{OD}\right) \delta$ ppm 8.31 (d, $J=0.98 \mathrm{~Hz}, 1 \mathrm{H}) 8.19$ (d, J=2.54 Hz, 1 H) 8.14 (s, $1 \mathrm{H}) 7.47$ (t, J=1.76 Hz, 1 H) 6.41 (s, 1 H) 4.39 - $4.48(\mathrm{~m}, 1 \mathrm{H}) 3.75$ - $3.85(\mathrm{~m}, 1 \mathrm{H}) 2.83(\mathrm{~s}, 3 \mathrm{H}) 2.51$ - $2.60(\mathrm{~m}, 2 \mathrm{H}) 2.36-2.43(\mathrm{~m}, 5 \mathrm{H})$.

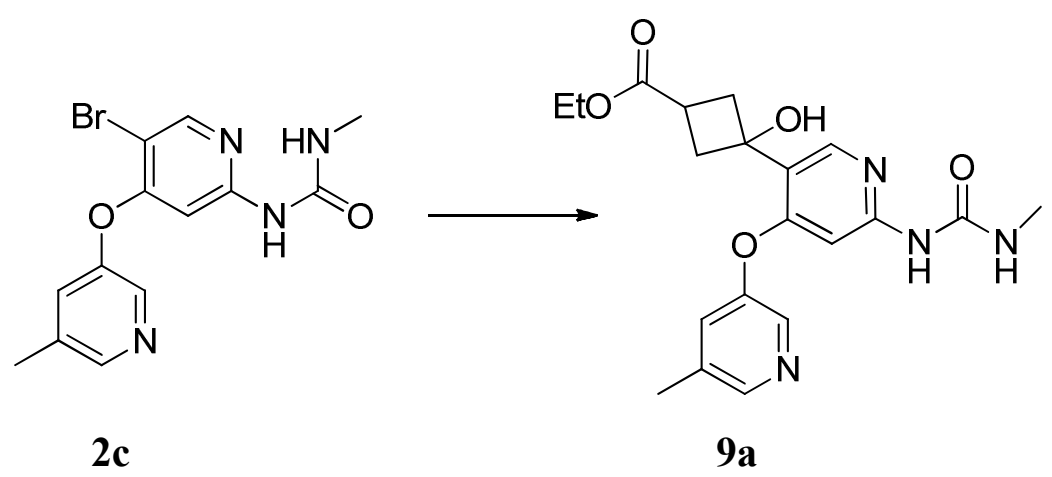


Ethyl 3-Hydroxy-3-(4-((5-methylpyridin-3-yl)oxy)-6-(3-methylureido)pyridin-3-

yl)cyclobutanecarboxylate 9a: follow the same procedure to synthesize 7a, using ethyl 3oxocyclobutanecarboxylate as the electrophile. Only one isomer was isolated after silica gel chromatography. ESI (pos.) m/e: $401.1(\mathrm{M}+\mathrm{H}) .{ }^{1} \mathrm{H}$ NMR (400 MHz, $\left.\mathrm{CD}_{3} \mathrm{OD}\right) \delta$ ppm $8.25-8.35$ $(\mathrm{m}, 3 \mathrm{H}) 7.53-7.56(\mathrm{~m}, 1 \mathrm{H}) 6.45(\mathrm{~s}, 1 \mathrm{H}) 4.16(\mathrm{q}, J=7.04 \mathrm{~Hz}, 2 \mathrm{H}) 3.06-3.13(\mathrm{~m}, 2 \mathrm{H}) 2.77$ $2.88(\mathrm{~m}, 4 \mathrm{H}) 2.61-2.69(\mathrm{~m}, 2 \mathrm{H}) 2.42(\mathrm{~s}, 3 \mathrm{H}) 1.26(\mathrm{t}, J=7.14 \mathrm{~Hz}, 3 \mathrm{H})$.

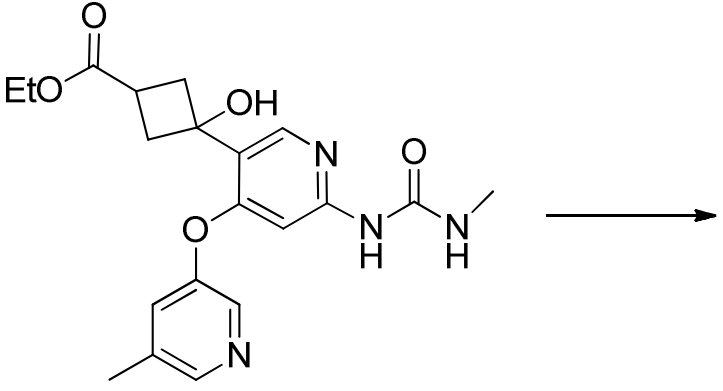

9a<smiles>CCOC(=O)C1CC(c2cnc(NC(=O)NC)cc2Oc2cncc(C)c2)C1</smiles>

9b

(1R,3R)-Ethyl 3-(4-((5-Methylpyridin-3-yl)oxy)-6-(3-methylureido)pyridin-3-

yl)cyclobutanecarboxylate 9b: Follow the same procedure to make $\mathbf{7}$ from $\mathbf{7 a}$. Just one isomer was isolated and based on the NMR assignment of compound 7, this was assigned as the cisisomer as well. ESI (pos.) m/e: $385.1(\mathrm{M}+\mathrm{H}) .{ }^{1} \mathrm{H} \mathrm{NMR}\left(400 \mathrm{MHz}, \mathrm{CD}_{3} \mathrm{OD}\right) \delta \mathrm{ppm} 8.31(\mathrm{~s}, 1 \mathrm{H})$ $8.20(\mathrm{~d}, J=2.35 \mathrm{~Hz}, 1 \mathrm{H}) 8.06(\mathrm{~s}, 1 \mathrm{H}) 7.46-7.49(\mathrm{~m}, 1 \mathrm{H}) 6.41(\mathrm{~s}, 1 \mathrm{H}) 4.11$ (q, J=7.04 Hz, $2 \mathrm{H})$ $3.61-3.72(\mathrm{~m}, 1 \mathrm{H}) 3.15-3.26(\mathrm{~m}, 1 \mathrm{H}) 2.82(\mathrm{~s}, 3 \mathrm{H}) 2.58-2.68(\mathrm{~m}, 2 \mathrm{H}) 2.39$ - $2.51(\mathrm{~m}, 5 \mathrm{H})$ $1.18-1.29(\mathrm{~m}, 3 \mathrm{H})$.<smiles>CCOC(=O)C1CC(c2cnc(NC(=O)NC)cc2Oc2cncc(C)c2)C1</smiles>

9b<smiles>CNC(=O)Nc1cc(Oc2cncc(C)c2)c(C2CC(CO)C2)cn1</smiles>

9

1-(5-((1R,3R)-3-(Hydroxymethyl)cyclobutyl)-4-((5-methylpyridin-3-yl)oxy)pyridin-2-yl)-3methylurea 9: A flask with (1R,3R)-ethyl 3-(4-((5-methylpyridin-3-yl)oxy)-6-(3methylureido)pyridin-3-yl)cyclobutanecarboxylate $9 \mathbf{b}$ (13 mg, $0.03 \mathrm{mmol}$ ) was azeotroped with 
toluene. THF $(1.0 \mathrm{~mL})$ was added under nitrogen. The reaction was cooled down in an ice-bath. Diisobutylaluminum hydride, 25 wt. \% (1.5 M) in toluene (140 $\mu \mathrm{L}, 0.20 \mathrm{mmol})$ was added and stirring was continued at $0{ }^{\circ} \mathrm{C}$ for $1 \mathrm{hr}$.. The reaction was quenched with satd. Rochelle's salt soln. and extracted with EtOAc. The EtOAc layer was concentrated and purified on a pre-packed silica gel column with gradient $0-70 \%$ EtOAc in heptanes and then gradient $0-8 \% \mathrm{MeOH}$ in DCM to provide $(9.8 \mathrm{mg}, 0.026 \mathrm{mmol}, 85 \%$ yield $)$ of 1-(5-((1R,3R)-3(hydroxymethyl)cyclobutyl)-4-((5-methylpyridin-3-yl)oxy)pyridin-2-yl)-3-methylurea 9 as a clear oil. ESI (pos.) m/e: $343.1(\mathrm{M}+\mathrm{H}) .{ }^{1} \mathrm{H}$ NMR (400 MHz, $\left.\mathrm{CD}_{3} \mathrm{OD}\right) \delta$ ppm 8.30 (s, $\left.1 \mathrm{H}\right) 8.18$ $(\mathrm{d}, J=2.54 \mathrm{~Hz}, 1 \mathrm{H}) 8.05(\mathrm{~s}, 1 \mathrm{H}) 7.44-7.46(\mathrm{~m}, 1 \mathrm{H}) 6.40(\mathrm{~s}, 1 \mathrm{H}) 3.46-3.61(\mathrm{~m}, 3 \mathrm{H}) 2.82$ (s, 3 H) $2.41-2.55(\mathrm{~m}, 3 \mathrm{H}) 2.40(\mathrm{~s}, 3 \mathrm{H}) 1.95$ - 2.04 (m, 2 H).

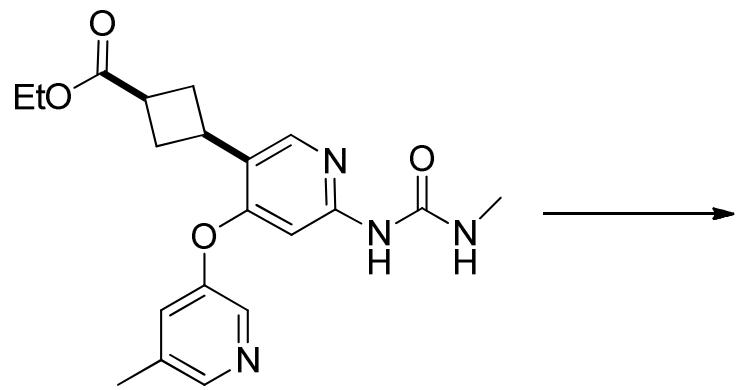

9b

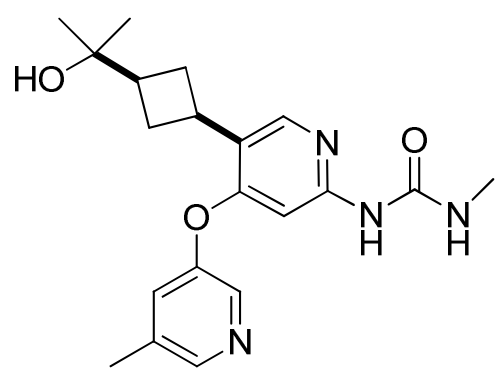

10

1-(5-((1R,3R)-3-(2-hydroxypropan-2-yl)cyclobutyl)-4-((5-methylpyridin-3-yl)oxy)pyridin-2yl)-3-methylurea 10: A flask with (1R,3R)-ethyl 3-(4-((5-methylpyridin-3-yl)oxy)-6-(3methylureido)pyridin-3-yl)cyclobutanecarboxylate 9b (24 mg, $0.064 \mathrm{mmol})$ was azeotroped with toluene and then purged with nitrogen. The reaction was first dissolved in THF (1.5 mL) and cooled down in an ice-bath. To the solution was added methyllithium (1.6M in diethyl ether) $(0.33 \mathrm{~mL}, 0.47 \mathrm{mmol})$ dropwise. After $5 \mathrm{~min}$., the reaction was allowed to warm up to room temperature and stirred for one hour. Then the reaction was quenched with saturated $\mathrm{NH}_{4} \mathrm{Cl}$ and extracted with EtOAc. The EtOAc layer was concentrated and purified on a prepacked silica gel column with gradient $0-70 \%$ EtOAc in heptanes and then gradient $0-8 \% \mathrm{MeOH}$ in DCM to provide (13.4 mg, $0.037 \mathrm{mmol}, 58 \%$ yield) of 1-(5-((1R,3R)-3-(2-hydroxypropan-2yl)cyclobutyl)-4-((5-methylpyridin-3-yl)oxy)pyridin-2-yl)-3-methylurea 10. ESI (pos.) m/e: $371.1(\mathrm{M}+\mathrm{H}) .{ }^{1} \mathrm{H}$ NMR $\left(400 \mathrm{MHz}, \mathrm{CD}_{3} \mathrm{OD}\right) \delta \mathrm{ppm} 8.30(\mathrm{~s}, 1 \mathrm{H}) 8.18(\mathrm{~d}, J=2.54 \mathrm{~Hz}, 1 \mathrm{H}) 8.08$ 
$(\mathrm{s}, 1 \mathrm{H}) 7.45(\mathrm{~s}, 1 \mathrm{H}) 6.40(\mathrm{~s}, 1 \mathrm{H}) 3.39-3.51(\mathrm{~m}, 1 \mathrm{H}) 2.82(\mathrm{~s}, 3 \mathrm{H}) 2.40(\mathrm{~s}, 3 \mathrm{H}) 2.25$ - $2.38(\mathrm{~m}$, 3 H) $2.09-2.20(\mathrm{~m}, 2 \mathrm{H}) 1.12(\mathrm{~s}, 6 \mathrm{H})$.

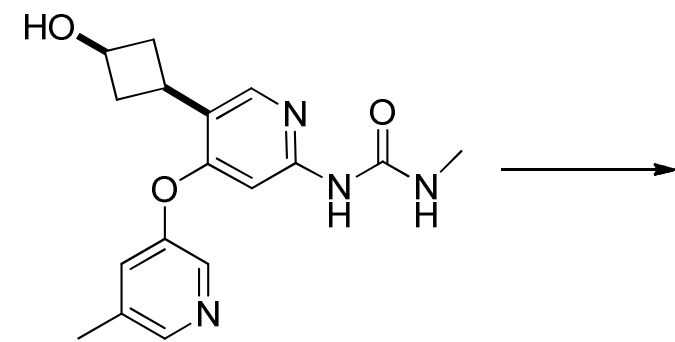

7<smiles>CNC(=O)Nc1cc(Oc2cncc(C)c2)c(C2CC(=O)C2)cn1</smiles>

$11 \mathrm{a}$

\section{1-Methyl-3-(4-((5-methylpyridin-3-yl)oxy)-5-(3-oxocyclobutyl)pyridin-2-yl)urea 11a: A}

flask was charged with 1-(5-((1R,3R)-3-hydroxycyclobutyl)-4-((5-methylpyridin-3-

yl)oxy)pyridin-2-yl)-3-methylurea 7 (35 mg, $0.11 \mathrm{mmol}$ ) and Dess-Martin reagent (59 mg, 0.14 mmol). Then DCM $(3.0 \mathrm{~mL})$ was added. The reaction was stirred at room temperature for one hour and quenched with saturated $\mathrm{NaHCO}_{3}$. The mixture was extracted with EtOAc. The EtOAc layer was dried over magnesium sulfate, concentrated and purified on a pre-packed silica gel column with gradient 0-8\% MeOH/DCM to provide (35 mg, $0.14 \mathrm{mmol}$, 99\% yield) 1-methyl-3(4-((5-methylpyridin-3-yl)oxy)-5-(3-oxocyclobutyl)pyridin-2-yl)urea 11a as a white solid. ESI (pos.) m/e: $327.1(\mathrm{M}+\mathrm{H}) .{ }^{1} \mathrm{H}$ NMR (400 MHz, CD $\left.3 \mathrm{OD}\right) \delta$ ppm 8.34 (d, $\left.J=11.46 \mathrm{~Hz}, 1 \mathrm{H}\right) 8.24$ $(\mathrm{d}, J=2.54 \mathrm{~Hz}, 1 \mathrm{H}) 8.18(\mathrm{~s}, 1 \mathrm{H}) 7.52$ - $7.55(\mathrm{~m}, 1 \mathrm{H}) 6.47(\mathrm{~s}, 1 \mathrm{H}) 3.77$ - $3.86(\mathrm{~m}, 1 \mathrm{H}) 3.46$ $3.54(\mathrm{~m}, 2 \mathrm{H}) 3.34-3.44(\mathrm{~m}, 2 \mathrm{H}) 2.82(\mathrm{~s}, 3 \mathrm{H}) 2.42(\mathrm{~s}, 3 \mathrm{H})$.

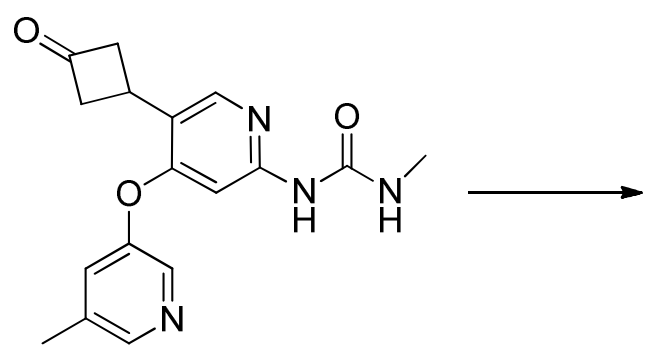

$11 \mathrm{a}$

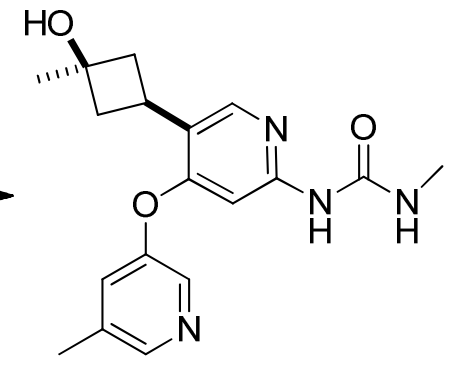

11

\section{1-(5-((1R,3R)-3-Hydroxy-3-methylcyclobutyl)-4-((5-methylpyridin-3-yl)oxy)pyridin-2-yl)-3-} methylurea 11: A flask with 1-methyl-3-(4-((5-methylpyridin-3-yl)oxy)-5-(3oxocyclobutyl)pyridin-2-yl)urea 11a (20 mg, $0.061 \mathrm{mmol})$ was azeotroped with toluene and then purged with nitrogen. THF $(2.0 \mathrm{~mL})$ was added and the solution was cooled down in an icebath. To the solution was added methyllithium solution, $1.6 \mathrm{M}$ in diethyl ether $(0.29 \mathrm{~mL}, 0.46$ 
mmol) dropwise. After five min. of stirring in the ice bath, the reaction was allowed to warm to room temperature and stirred for one hour. Then the reaction was quenched with saturated $\mathrm{NH}_{4} \mathrm{Cl}$ and extracted with EtOAc. The EtOAc layer was dried over magnesium sulfate, concentrated and purified on reverse phase HPLC $\left(0.1 \% \mathrm{TFA}\right.$ in $\mathrm{CH}_{3} \mathrm{CN} /$ water, $10-70 \%$ gradient $)$ to provide (4.5 $\mathrm{mg}, 0.013 \mathrm{mmol}, 22 \%$ yield) of 1-(5-((1R,3R)-3-hydroxy-3-methylcyclobutyl)-4((5-methylpyridin-3-yl)oxy)pyridin-2-yl)-3-methylurea 11 as a colorless oil. ESI (pos.) m/e: $343.2(\mathrm{M}+\mathrm{H}) .{ }^{1} \mathrm{H}$ NMR $\left(400 \mathrm{MHz}, \mathrm{CD}_{3} \mathrm{OD}\right) \delta \mathrm{ppm} 8.31$ (d, $\left.J=0.98 \mathrm{~Hz}, 1 \mathrm{H}\right) 8.19(\mathrm{~d}, J=2.54 \mathrm{~Hz}$, $1 \mathrm{H}) 8.08(\mathrm{~s}, 1 \mathrm{H}) 7.44-7.47(\mathrm{~m}, 1 \mathrm{H}) 6.40(\mathrm{~s}, 1 \mathrm{H}) 3.18$ - $3.28(\mathrm{~m}, 1 \mathrm{H}) 2.82(\mathrm{~s}, 3 \mathrm{H}) 2.43$ - 2.51 (m, 2 H) 2.41 (s, 3 H) $2.21-2.33(\mathrm{~m}, 2 \mathrm{H}) 1.44(\mathrm{~s}, 3 \mathrm{H})$.

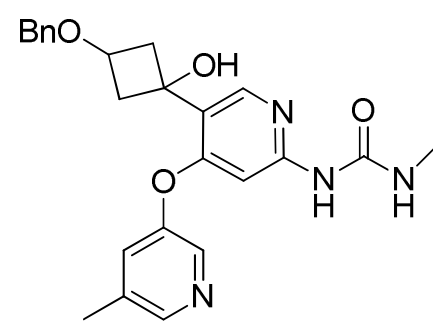

$7 \mathbf{a}$

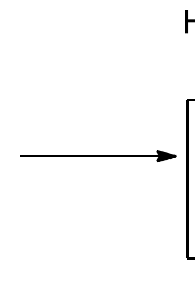<smiles>CNC(=O)Nc1cc(Oc2cncc(C)c2)c(C2(O)CC(O)C2)cn1</smiles>

12a

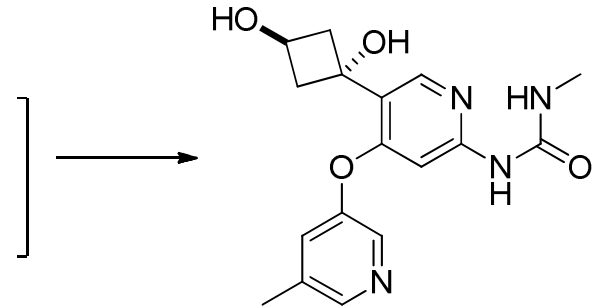

12

\section{1-(5-((1R,3R)-1,3-Dihydroxycyclobutyl)-4-((5-methylpyridin-3-yl)oxy)pyridin-2-yl)-3-}

methylurea 12: Compound 12 was a minor product isolated from a large scale reaction to prepare compound 7 under a slightly different procedure: To a $250 \mathrm{~mL}$ round bottom flask containing $45 \mathrm{~mL}$ of ethanol was added 1-(5-(3-(benzyloxy)-1-hydroxycyclobutyl)-4-((5methylpyridin-3-yl)oxy)pyridin-2-yl)-3-methylurea $7 \mathrm{a}(5.1 \mathrm{~g}, 12 \mathrm{mmol})$. The milky solution was cooled in an ice bath. After 10 minutes, methanesulfonic acid $(15 \mathrm{ml}, 230 \mathrm{mmol})$ was added dropwise. The solution becomes clear yellow.

To a glass flask was added palladium 10 wt. \% (dry basis) on activated carbon, wet Degussa Type e101 NE/W ( $4.01 \mathrm{~g}, 3.77 \mathrm{mmol})$ then $20 \mathrm{~mL}$ of ethanol. The above contents in the $250 \mathrm{~mL}$ flask were carefully transferred into the glass flask containing catalyst and ethanol. Nitrogen was bubbled through the solution for 10 minutes. The reaction mixture was evacuated and backfilled with hydrogen. This sequence was repeated three times. The reaction was hydrogenated at $100 \mathrm{psi}$ using a Parr hydrogenation apparatus. 
After 40 hours, the reaction was carefully filtered through a pad of diatomaceous earth. The mixture was rinsed with ethanol and then methanol. The mixture was concentrated to afford a light yellow liquid that was carefully neutralized with dropwise addition of $\sim 2 \mathrm{M}$ aqueous sodium hydroxide solution. After adjusting the $\mathrm{pH}$ to $\sim 8$, the mixture was extracted three times with $30 \%$ isopropanol in chloroform. The organics were pooled then dried over anhydrous magnesium sulfate. After filtration and concentration, the residue was dry loaded onto a silica gel column then chromatographed using 10-65 \% of premixed 3:1 ethyl acetate: ethanol solution in heptane to afford compound 7 as a white solid ( $2.1 \mathrm{~g}, 6.5 \mathrm{mmol}, 55 \%$ yield). The column was further flushed with $10 \% \mathrm{MeOH}$ in DCM to afford a light yellow film as impure 1-(5-(1,3dihydroxycyclobutyl)-4-((5-methylpyridin-3-yl)oxy)pyridin-2-yl)-3-methylurea 12a (280 mg, $0.82 \mathrm{mmol}, 6.9 \%$ yield) that was submitted for further chiral separation. ESI (pos.) m/e: 345.4 $(\mathrm{M}+\mathrm{H})^{+}$. Chiral separation condition for 12a: $250 \times 30 \mathrm{~mm} \times$ IC column with $60 \mathrm{~g} / \mathrm{min} \mathrm{MeOH}+$ $\left(20 \mathrm{mM} \mathrm{NH}_{3}\right)+60 \mathrm{~g} / \mathrm{min} \mathrm{CO}_{2}$ on Thar $200 \mathrm{SFC}$. Outlet pressure $=100$ bar; Temp. $=20 \mathrm{C}$; Wavelength $=240 \mathrm{~nm}$. Used $1.5 \mathrm{ml}$ injections of $260 \mathrm{mg} / 20 \mathrm{~mL}(13 \mathrm{mg} / \mathrm{mL})$ sample solution in $\mathrm{MeOH}$, i.e. $20 \mathrm{mg} /$ injection. Run time $=15 \mathrm{~min}$, cycle time $=9 \mathrm{~min}$.

Compound 12 was the first peak off chiral column. ESI (pos.) m/e: $345.5(\mathrm{M}+\mathrm{H}) .{ }^{1} \mathrm{H}$ NMR $\left(500 \mathrm{MHz}, \mathrm{DMSO}-\mathrm{d}_{6}\right) \delta \mathrm{ppm} 9.04(\mathrm{~s}, 1 \mathrm{H}), 8.30-8.35$ (m, $\left.1 \mathrm{H}\right), 8.22(\mathrm{~d}, J=2.7 \mathrm{~Hz}, 1 \mathrm{H}), 8.02(\mathrm{~s}$, $1 \mathrm{H}), 7.78$ (br. s, $1 \mathrm{H}), 7.43$ (s, $1 \mathrm{H}), 6.74$ (s, $1 \mathrm{H}), 5.18$ (s, $1 \mathrm{H}), 4.96$ (d, J=6.6 Hz, 1H) 4.42 (sxt, $J=7.1 \mathrm{~Hz}, 1 \mathrm{H}), 2.65(\mathrm{~d}, J=4.6 \mathrm{~Hz}, 3 \mathrm{H}), 2.56-2.63(\mathrm{~m}, 2 \mathrm{H}), 2.33$ - 2.37 (m, $3 \mathrm{H}), 2.28$ - $2.33(\mathrm{~m}$, $2 \mathrm{H}$ ). Its stereochemistry was confirmed by NMR (HSQC, NOESY).

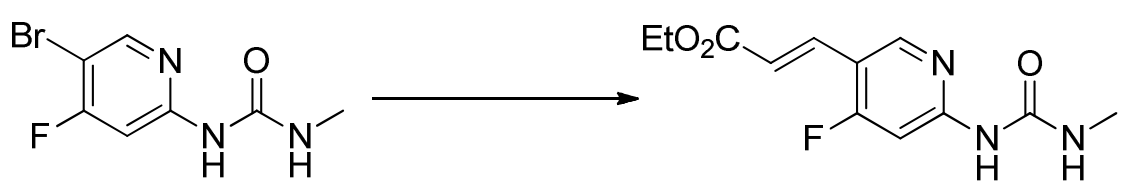

2a

$13 a$

(E)-Ethyl 3-(4-fluoro-6-(3-methylureido)pyridin-3-yl)acrylate (13a). To a $250 \mathrm{~mL}$ round bottom flask was added compound $\mathbf{2 . 2}(2.0 \mathrm{~g}, 8.1 \mathrm{mmol})$, 2-ethoxycarbonylvinylboronic acid pinacol ester (2.5 mL, $11 \mathrm{mmol}$ ), dichlorobis(triphenylphosphine)palladium (II) (0.57 g, 0.81 mmol) and sodium carbonate $(4.3 \mathrm{~g}, 40 \mathrm{mmol})$ and a $4: 1$ mixture of dioxane:water $(75 \mathrm{~mL})$. The reaction was purged with argon then heated under argon for $18 \mathrm{~h}$ at $80^{\circ} \mathrm{C}$. The reaction mixture 
was diluted with water and extracted with $10 \% \mathrm{MeOH}$ in $\mathrm{CH}_{2} \mathrm{Cl}_{2}$. The organic extract was dried over $\mathrm{MgSO}_{4}$. The solution was filtered and concentrated in vacuo. The crude product was triturated with ether to give white solid. The filtrate was concentrated in vacuo. The crude product was absorbed onto a plug of silica gel and purified by chromatography through a prepacked silica gel column (80 g), eluting with a gradient of $0 \%$ to $100 \%$ EtOAc in hexane which was combined with the triturated solid to give the title compound (13a) (1.5 g, $5.6 \mathrm{mmol}, 70 \%$ yield). MS ESI (pos.) m/e: $268.0(\mathrm{M}+\mathrm{H}) .{ }^{1} \mathrm{H}$ NMR $\left(400 \mathrm{MHz}, D M S O-d_{6}\right) \delta \mathrm{ppm} 9.65(\mathrm{~s}, 1 \mathrm{H})$, 8.65 (d, $J=10.8 \mathrm{~Hz}, 1 \mathrm{H}), 7.58$ (d, $J=16.2 \mathrm{~Hz}, 1 \mathrm{H}), 7.48$ (d, J=13.7 Hz, $1 \mathrm{H}), 7.33$ (d, J=4.5 Hz, 1 $\mathrm{H}), 6.60(\mathrm{~d}, J=16.2 \mathrm{~Hz}, 1 \mathrm{H}), 4.21(\mathrm{~d}, J=7.2 \mathrm{~Hz}, 2 \mathrm{H}), 2.72(\mathrm{~d}, J=4.7 \mathrm{~Hz}, 3 \mathrm{H}), 1.27$ (t, $J=7.1 \mathrm{~Hz}$, $3 \mathrm{H})$.

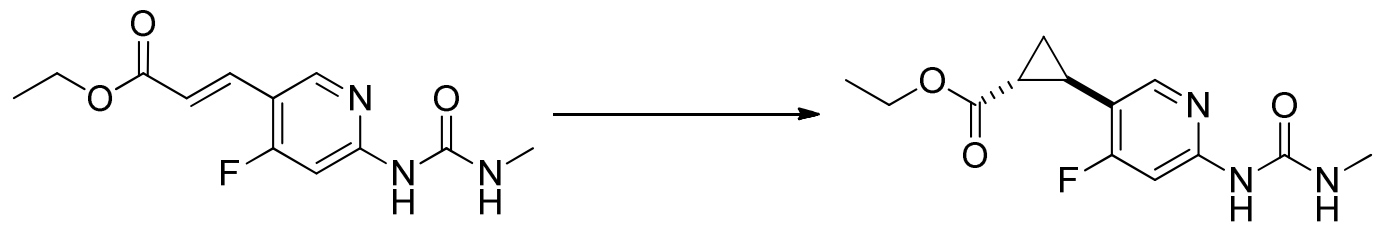

13a

13b

trans-Ethyl 2-(4-Fluoro-6-(3-methylureido)pyridin-3-yl)cyclopropanecarboxylate (13b).

To a solution of $60 \% \mathrm{NaH}$ in mineral oil $(0.07 \mathrm{~g}, 1.8 \mathrm{mmol})$ in DMSO $(4.0 \mathrm{~mL})$ was added trimethylsulfoxonium iodide $(0.39 \mathrm{~g}, 1.8 \mathrm{mmol})$. The reaction mixture was stirred at room temperature for one hour. Compound 13a (0.32 g, $1.2 \mathrm{mmol})$ in DMSO (3.0 mL) was added. The reaction mixture was stirred at room temperature for $24 \mathrm{~h}$. The reaction mixture was diluted with water, then extracted with EtOAc. The organic extract was dried over $\mathrm{MgSO}_{4}$. The solution was filtered and concentrated in vacuo. The crude material was adsorbed onto a plug of silica gel and purified by chromatography through a pre-packed silica gel column (12 g), eluting with a gradient of $0 \%$ to $100 \%$ EtOAc in hexane, to provide the title compound (13b) (93 mg, 0.33 mmol, 28\% yield) as a white solid. MS ESI (pos.) m/e: $282.1(\mathrm{M}+\mathrm{H}) .{ }^{1} \mathrm{H} \mathrm{NMR}(500 \mathrm{MHz}$, $\left.\mathrm{CDCl}_{3}\right) \delta$ ppm $7.92(\mathrm{~s}, 1 \mathrm{H}), 7.78$ (d, $\left.J=7.6 \mathrm{~Hz}, 1 \mathrm{H}\right), 4.22$ (q, $\left.J=7.3 \mathrm{~Hz}, 2 \mathrm{H}\right), 2.90$ (d, $J=4.6 \mathrm{~Hz}$, $3 \mathrm{H}), 2.42$ - 2.59 (m, $1 \mathrm{H}), 1.95$ (ddd, $J=8.7,5.3,4.5 \mathrm{~Hz}, 1 \mathrm{H}), 1.69$ (dt, J=9.2, 5.3 Hz, $1 \mathrm{H}), 1.22$ $-1.40(\mathrm{~m}, 4 \mathrm{H})$. 


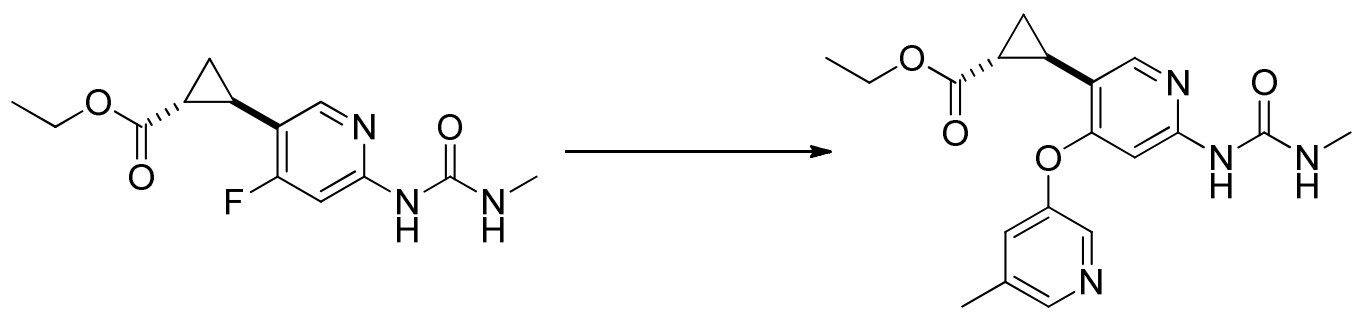

13b

$13 \mathrm{c}$

trans-Ethyl 2-(4-((5-Methylpyridin-3-yl)oxy)-6-(3-methylureido)pyridin-3-

yl)cyclopropanecarboxylate (13c). To a screwed cap vial was added compound 13.2 (0.21 g, $0.73 \mathrm{mmol}), 3$-hydroxy-5-methylpyridine $(0.11 \mathrm{~g}, 1.0 \mathrm{mmol})$ and cesium fluoride $(0.17 \mathrm{~g}, 1.1$ mmol) in $\mathrm{CH}_{3} \mathrm{CN}(4.0 \mathrm{~mL})$. The reaction mixture was stirred at $80{ }^{\circ} \mathrm{C}$ for two days. The crude product was purified by chromatography through a pre-packed silica gel column (12 g), eluting with a gradient of $0 \%$ to $4 \% \mathrm{MeOH}$ in $\mathrm{CH}_{2} \mathrm{Cl}_{2}$ to afford the title compound (13c) (57 mg, 0.15 mmol, 21\% yield) as a white solid. MS ESI (pos.) m/e: $371.2(\mathrm{M}+\mathrm{H}) .{ }^{1} \mathrm{H}$ NMR (500 MHz, $\left.\mathrm{CD}_{3} \mathrm{OD}\right) \delta \mathrm{ppm} 8.48(\mathrm{~s}, 1 \mathrm{H}), 8.40(\mathrm{~d}, J=2.4 \mathrm{~Hz}, 1 \mathrm{H}), 7.97(\mathrm{~s}, 1 \mathrm{H}), 7.73(\mathrm{~s}, 1 \mathrm{H}), 6.42(\mathrm{~s}, 1 \mathrm{H}), 4.15$ (q, $J=7.1 \mathrm{~Hz}, 2 \mathrm{H}), 2.80(\mathrm{~s}, 3 \mathrm{H}), 2.54-2.65(\mathrm{~m}, 1 \mathrm{H}), 2.47$ (s, 3H), $1.94-2.07$ (m, 1H), $1.56-$ $1.63(\mathrm{~m}, 1 \mathrm{H}), 1.53(\mathrm{dd}, J=8.6,6.6 \mathrm{~Hz}, 1 \mathrm{H}), 1.23(\mathrm{t}, J=7.1 \mathrm{~Hz}, 3 \mathrm{H})$.

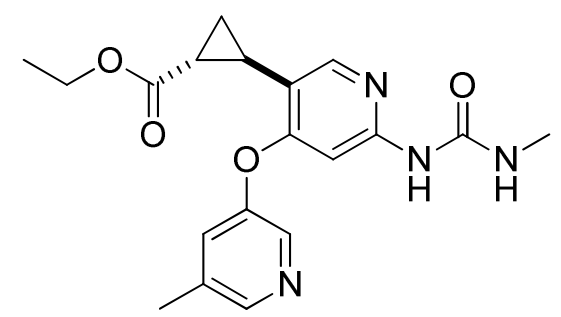

$13 \mathbf{c}$

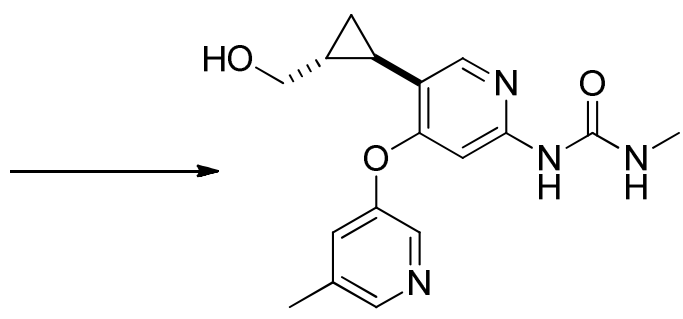

13

\section{1-(5-(trans-2-(Hydroxymethyl)cyclopropyl)-4-((5-methylpyridin-3-yl)oxy)pyridin-2-yl)-3-}

methylurea (13). To a $50 \mathrm{~mL}$ round bottom flask was added compound $13 \mathrm{c}(25 \mathrm{mg}, 0.07 \mathrm{mmol})$ in THF $(1.0 \mathrm{~mL})$. Diisobutylaluminum hydride, $1.5 \mathrm{M}$ in toluene $(0.10 \mathrm{~mL}, 0.15 \mathrm{mmol})$ was added at $0{ }^{\circ} \mathrm{C}$ and the reaction mixture was stirred at $0{ }^{\circ} \mathrm{C}$. After one hour, more diisobutylaluminum hydride, $1.5 \mathrm{M}$ in toluene $(0.10 \mathrm{~mL}, 0.15 \mathrm{mmol})$ was added. The reaction 
was stirred for an additional one hour. The reaction was quenched with aqueous Rochelle's salt solution and extracted with EtOAc. The organic extract was collected and dried over $\mathrm{MgSO}_{4}$. The solution was filtered and concentrated in vacuo. The crude material was adsorbed onto a plug of silica gel and purified by medium pressure chromatography through a pre-packed silica gel column (4 g), eluting with a gradient of $0 \%$ to $10 \% \mathrm{MeOH}$ in $\mathrm{CH}_{2} \mathrm{Cl}_{2}$, to give the title compound (13) (20 mg, 0.06 mmol, 90\% yield) as white solid. MS ESI (pos.) m/e: 329.2 $(\mathrm{M}+\mathrm{H}) .{ }^{1} \mathrm{H}$ NMR $\left(500 \mathrm{MHz}, \mathrm{CD}_{3} \mathrm{OD}\right) \delta \mathrm{ppm} 8.30(\mathrm{~s}, 1 \mathrm{H}), 8.22(\mathrm{~d}, J=2.45 \mathrm{~Hz}, 1 \mathrm{H}), 7.91(\mathrm{~s}$, 1H), $7.48(\mathrm{~s}, 1 \mathrm{H}), 6.44(\mathrm{~s}, 1 \mathrm{H}), 3.53(\mathrm{dd}, J=2.93,6.36 \mathrm{~Hz}, 2 \mathrm{H}), 2.77$ - $2.86(\mathrm{~m}, 3 \mathrm{H}), 2.41(\mathrm{~s}$, $3 \mathrm{H}), 1.82-1.97(\mathrm{~m}, 1 \mathrm{H}), 1.42(\mathrm{~d}, J=7.83 \mathrm{~Hz}, 1 \mathrm{H}), 1.01(\mathrm{td}, J=5.07,8.44 \mathrm{~Hz}, 1 \mathrm{H}), 0.91(\mathrm{td}, J$ $=5.20,8.93 \mathrm{~Hz}, 1 \mathrm{H})$.

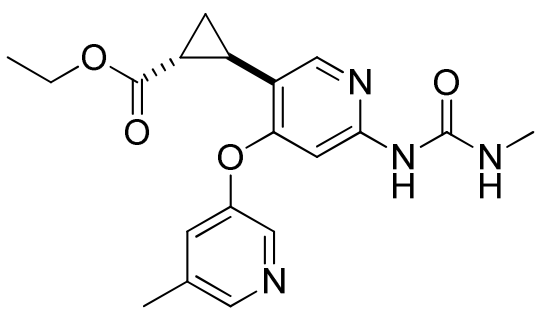

$13 \mathrm{c}$

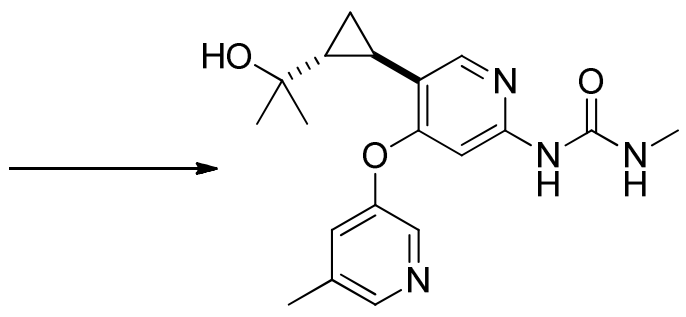

14

\section{1-(5-(trans-2-(2-Hydroxypropan-2-yl)cyclopropyl)-4-((5-methylpyridin-3-yl)oxy)pyridin-2-}

yl)-3-methylurea (14). A round bottom flask charged with compound 13c (25 mg, $0.070 \mathrm{mmol})$ was azeotroped with toluene and then purged with argon. The compound was dissolved in THF $(1 \mathrm{~mL})$ and cooled to $0{ }^{\circ} \mathrm{C}$. To the solution was added methyllithium, $1.6 \mathrm{M}$ solution in diethyl ether $(0.32 \mathrm{~mL}, 0.51 \mathrm{mmol})$ dropwise. After $5 \mathrm{~min}$, the reaction was warmed to room temperature and stirred for one hour. The mixture turned yellow. The reaction was quenched with saturated $\mathrm{NH}_{4} \mathrm{Cl}$ solution and extracted with EtOAc. The organic layers were collected, dried over $\mathrm{MgSO}_{4}$ and concentrated in vacuo. The crude material was adsorbed onto a plug of silica gel and purified by medium pressure chromatography through a pre-packed silica gel column (4 g), eluting with a gradient of $0 \%$ to $10 \% \mathrm{MeOH}$ in $\mathrm{CH}_{2} \mathrm{Cl}_{2}$, to provide 1-(5-(trans-2(2-hydroxypropan-2-yl)cyclopropyl)-4-((5-methylpyridin-3-yl)oxy)pyridin-2-yl)-3-methylurea (22.0 $\mathrm{mg}, 0.061 \mathrm{mmol}, 91 \%$ yield) as a white solid. The racemic mixture was separated by supercritical fluid chromatography $(250$ x $30 \mathrm{~mm} \mathrm{OJ-H}$ column on Thar 200 with $24 \mathrm{~g} / \mathrm{min}$ 
$\mathrm{MeOH}+\left(20 \mathrm{mM} \mathrm{NH}_{3}\right)+96 \mathrm{~g} / \mathrm{min} \mathrm{CO}_{2}$. Outlet pressure $=100 \mathrm{bar}$; temperature $=22^{0} \mathrm{C}$ wavelength $=214 \mathrm{~nm}$; injection volume $=0.3 \mathrm{~mL}, 5 \mathrm{mg} / \mathrm{mL} \mathrm{MeOH}: \mathrm{DCM} 3: 1$ ). Two enantiomers were obtained. The title compound (14) was the second isomer to elute under these conditions, and the structure was assigned arbitrarily. MS ESI (pos.) m/e: $357.3(\mathrm{M}+\mathrm{H}) .{ }^{1} \mathrm{H}$ NMR $\left(500 \mathrm{MHz}, \mathrm{CD}_{3} \mathrm{OD}\right) \delta$ ppm $8.31(\mathrm{~s}, 1 \mathrm{H}), 8.22(\mathrm{~d}, J=2.4 \mathrm{~Hz}, 1 \mathrm{H}), 7.91(\mathrm{~s}, 1 \mathrm{H}), 7.49$ (s, 1 H), $6.41(\mathrm{~s}, 1 \mathrm{H}), 2.81(\mathrm{~s}, 3 \mathrm{H}), 2.41(\mathrm{~s}, 3 \mathrm{H}), 1.99$ - $2.08(\mathrm{~m}, 1 \mathrm{H}), 1.27(\mathrm{~s}, 6 \mathrm{H}), 1.19$ - $1.24(\mathrm{~m}, 1$ H), 1.04 (dt, $J=8.9,5.3 \mathrm{~Hz}, 1 \mathrm{H}), 0.91$ (dt, $J=8.9,5.1 \mathrm{~Hz}, 1 \mathrm{H})$.

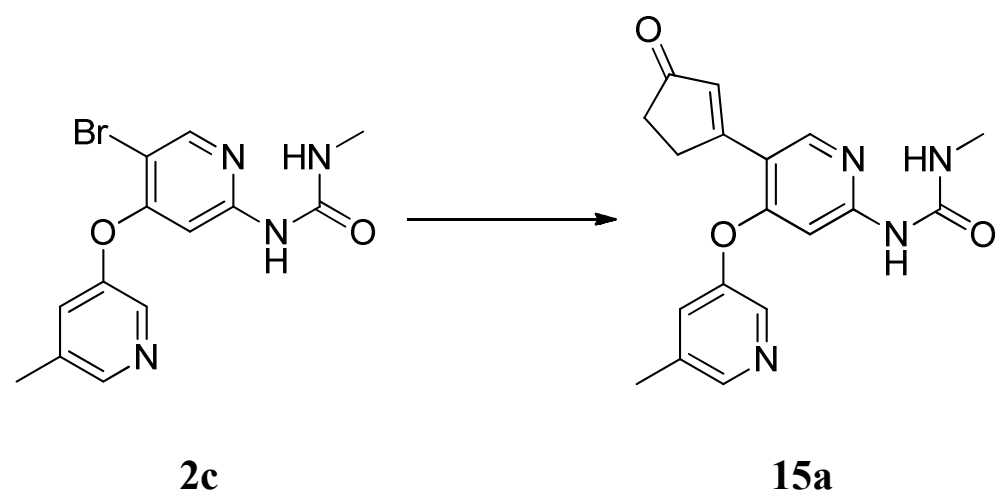

\section{1-Methyl-3-(4-((5-methylpyridin-3-yl)oxy)-5-(3-oxocyclopent-1-en-1-yl)pyridin-2-yl)urea}

(15a). A stream of nitrogen was bubbling through a mixture of compound 2.3 (2.0 g, $6.0 \mathrm{mmol})$, 2-cyclopenten-1-one $(1.5 \mathrm{~mL}, 18 \mathrm{mmol})$, sodium bicarbonate $(1.5 \mathrm{~g}, 18 \mathrm{mmol})$ and bis(triphenylphosphine)palladium (II) dichloride $(0.21 \mathrm{~g}, 0.30 \mathrm{mmol})$ in 1-methyl-2pyrrolidinone $(20 \mathrm{~mL})$ at room temperature for five minutes. The resulting mixture was sealed and then allowed to stir at $130{ }^{\circ} \mathrm{C}$ for 18 hours. The mixture was cooled to room temperature and filtered. The filtrate was concentrated, and the residue was adsorbed onto a plug of silica gel and purified by medium pressure chromatography through a pre-packed silica gel column ( $300 \mathrm{~g})$, eluting with a gradient of $0 \%$ to $10 \% \mathrm{MeOH}$ in $\mathrm{CH}_{2} \mathrm{Cl}_{2}$, to give the title compound (15a) (610 mg, 1.8 mmol, 30\% yield). MS ESI (pos.) m/e: $339.0(\mathrm{M}+\mathrm{H}) .{ }^{1} \mathrm{H}$ NMR (400 MHz, $\left.\mathrm{CDCl}_{3}\right) \delta$ ppm 9.46 (s, $1 \mathrm{H}), 9.06$ (d, J=3.91 Hz, $1 \mathrm{H}), 8.40$ (s, $1 \mathrm{H}), 8.38(\mathrm{~d}, J=0.98 \mathrm{~Hz}, 1 \mathrm{H}), 8.29$ (d, $J=2.54 \mathrm{~Hz}, 1 \mathrm{H}), 7.29$ (t, $J=1.76 \mathrm{~Hz}, 1 \mathrm{H}), 6.88$ (t, $J=1.57 \mathrm{~Hz}, 1 \mathrm{H}), 6.17$ (s, $1 \mathrm{H}), 3.13$ (td, $J=4.94,1.66 \mathrm{~Hz}, 2 \mathrm{H}), 2.78(\mathrm{~d}, J=4.69 \mathrm{~Hz}, 3 \mathrm{H}), 2.49-2.61(\mathrm{~m}, 2 \mathrm{H}), 2.41(\mathrm{~s}, 3 \mathrm{H})$. 


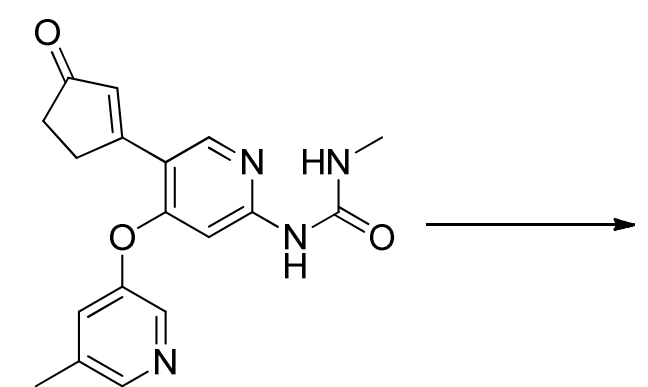

$15 \mathbf{a}$

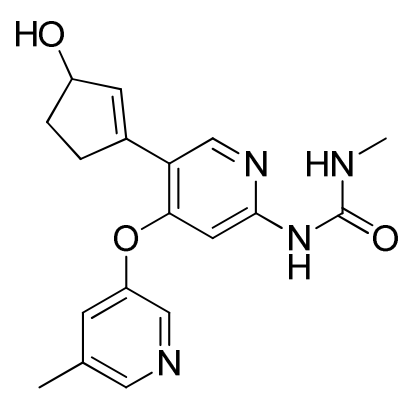

$15 b$

\section{1-(5-(3-Hydroxycyclopent-1-en-1-yl)-4-((5-methylpyridin-3-yl)oxy)pyridin-2-yl)-3-}

methylurea (15b) To a suspension of compound 15a (400 mg, $1.2 \mathrm{mmol})$ in tetrahydrofuran (15 $\mathrm{mL})$ was added dropwise lithium aluminum hydride, $1.0 \mathrm{M}$ solution in tetrahydrofuran $(1.30 \mathrm{~mL}$, $1.30 \mathrm{mmol}$ ) at $0{ }^{\circ} \mathrm{C}$. The resulting mixture was stirred at $0{ }^{\circ} \mathrm{C}$ for one hour, and then was quenched with saturated aqueous sodium bicarbonate solution. The mixture was directly adsorbed onto a plug of silica gel and purified by medium pressure chromatography through a pre-packed silica gel column (24 g), eluting with a gradient of $0 \%$ to $10 \% \mathrm{MeOH}$ in $\mathrm{CH}_{2} \mathrm{Cl}_{2}$, to provide the title compound (15b) (290 mg) with some impurity that was used directly in the next reaction. MS ESI (pos.) m/e: $341.1(\mathrm{M}+\mathrm{H})$.

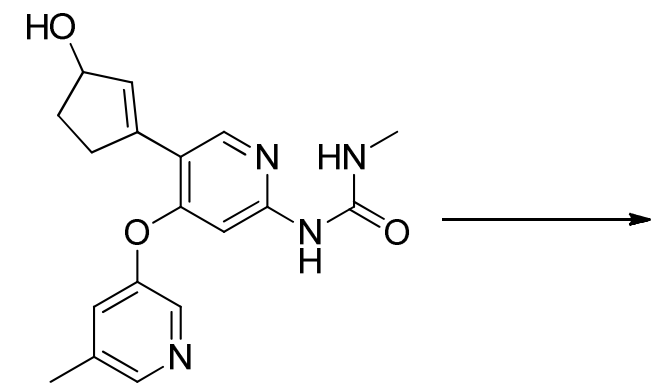

$15 b$<smiles>CNC(=O)Nc1cc(Oc2cncc(C)c2)c([C@H]2CCC(O)C2)cn1</smiles>

15

\section{1-(5-((1R,3R)-3-Hydroxycyclopentyl)-4-((5-methylpyridin-3-yl)oxy)pyridin-2-yl)-3-}

methylurea (15). A mixture of compound $15 \mathbf{b}(230 \mathrm{mg}, 0.69 \mathrm{mmol})$ and palladium hydroxide, $20 \mathrm{wt} \% \mathrm{Pd}$ (dry basis) on carbon, wet $(48 \mathrm{mg}, 0.074 \mathrm{mmol})$ in methanol $(22 \mathrm{~mL})$ under a balloon of hydrogen was allowed to stir at room temperature for 18 hours. The mixture was filtered, and the filtrate was concentrated. The crude material was adsorbed onto a plug of silica 
gel and purified by medium pressure chromatography through a pre-packed silica gel column (24 g), eluting with a gradient of $0 \%$ to $10 \% \mathrm{MeOH}$ in $\mathrm{CH}_{2} \mathrm{Cl}_{2}$, to give 1-(5-(3-hydroxycyclopentyl)4-((5-methylpyridin-3-yl)oxy)pyridin-2-yl)-3-methylurea ( $88 \mathrm{mg}, 0.26 \mathrm{mmol}, 38 \%$ yield). The mixture was separated by supercritical fluid chromatography ( 250 x $30 \mathrm{~mm}$ Lux-2 column on Thar 80 with $28 \mathrm{~g} / \mathrm{min} \mathrm{MeOH}+\left(20 \mathrm{mM} \mathrm{NH}_{3}\right)+52 \mathrm{~g} / \mathrm{min} \mathrm{CO} 2$. Outlet pressure $=100 \mathrm{bar}$; temperature $=24^{\circ} \mathrm{C}$ wavelength $=220 \mathrm{~nm}$; injection volume $=0.5 \mathrm{~mL}, 9.8 \mathrm{mg} / \mathrm{mL} \mathrm{MeOH}$ ). Four isomers were obtained. The title compound (15) was the third isomer to elute under these conditions, and the structure was assigned arbitrarily. MS ESI (pos.) m/e: $343.1(\mathrm{M}+\mathrm{H}) .{ }^{1} \mathrm{H}$ NMR (400 MHz, $\mathrm{CDCl}_{3}$ ) $\delta$ ppm 9.08 (br. s, 1H), 8.36 (br. s., 1H), 8.25 (br. s., 1H), 8.01 (s, $1 \mathrm{H}$ ), 7.32 (br. s., $1 \mathrm{H}$ ), 7.22 (s, 1H), 5.92 (s, 1H), 4.55 (br. s., 1H), 3.67-3.52 (m, 1H), 2.88 (d, $J=4.7$ $\mathrm{Hz}, 3 \mathrm{H}), 2.40$ (s, 3H), 2.34-2.24 (m, 1H), 2.24-2.14 (m, 1H), 2.13-2.05 (m, 1H), 2.01-1.91 (m, $1 \mathrm{H}), 1.78-1.66(\mathrm{~m}, 2 \mathrm{H})$.

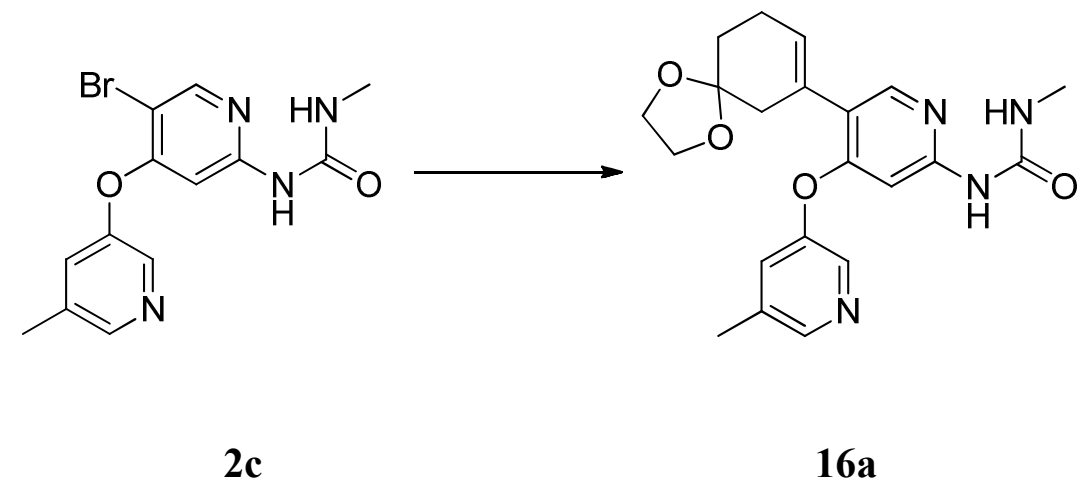

\section{1-Methyl-3-(4-((5-methylpyridin-3-yl)oxy)-5-(1,4-dioxaspiro[4.5]dec-7-en-7-yl)pyridin-2-}

yl)urea (16a). To a flask charged with dioxane $(9.0 \mathrm{ml})$ was added compound $\mathbf{2 c}(520 \mathrm{mg}, 1.5$ $\mathrm{mmol}$ ), 4,4,5,5-tetramethyl-2-(1,4-dioxaspiro[4.5]dec-7-en-7-yl)-1,3,2-dioxaborolane (450 mg, $1.7 \mathrm{mmol})$, tricyclohexylphosphine ( $86 \mathrm{mg}, 0.31 \mathrm{mmol})$, and $\mathrm{Pd}_{2}(\mathrm{dba})_{3}(140 \mathrm{mg}, 0.15 \mathrm{mmol})$. The reaction mixture was sparged with argon, then aqueous $\mathrm{K}_{3} \mathrm{PO}_{4}(1.3 \mathrm{M})(3.2 \mathrm{~mL}, 4.2 \mathrm{mmol})$ was added by syringe. The resulting reaction was heated to $95^{\circ} \mathrm{C}$ for one hour. The reaction was cooled and then diluted with ethyl acetate $(100 \mathrm{~mL})$ and water $(40 \mathrm{~mL})$. The layers were separated. The aqueous layer was extracted with ethyl acetate $(2 \times 100 \mathrm{~mL})$. The combined 
organic layers were then washed with brine $(1 \times 50 \mathrm{~mL})$ and dried over magnesium sulfate. The crude product was purified by medium pressure chromatography through a pre-packed silica gel column, eluting with a gradient of $0 \%$ to $7.5 \% \mathrm{MeOH}$ in $\mathrm{CH}_{2} \mathrm{Cl}_{2}$ to give the title compound (16a) (410 mg, $1.0 \mathrm{mmol}, 67 \%$ yield). MS ESI (pos.) m/e: $397.1(\mathrm{M}+\mathrm{H}) .{ }^{1} \mathrm{H}$ NMR (400 MHz, $\left.\mathrm{CDCl}_{3}\right) \delta$ ppm $9.20(\mathrm{~s}, 1 \mathrm{H}), 9.09(\mathrm{~d}, J=3.9 \mathrm{~Hz}, 1 \mathrm{H}), 8.28$ (d, $\left.J=1.0 \mathrm{~Hz}, 1 \mathrm{H}\right), 8.22$ (d, $J=2.7 \mathrm{~Hz}$, 1H), $7.97(\mathrm{~s}, 1 \mathrm{H}), 7.20(\mathrm{t}, J=1.8 \mathrm{~Hz}, 1 \mathrm{H}), 6.13(\mathrm{~s}, 1 \mathrm{H}), 5.88(\mathrm{dt}, J=3.7,2.0 \mathrm{~Hz}, 1 \mathrm{H}), 3.95-4.00$ (m, 4H), 2.77 (d, J=4.7 Hz, 3H), 2.63 (d, J=1.4 Hz, 2H), 2.38-2.45 (m, 2H), 2.35 (s, 3H), 1.79 (t, $J=6.6 \mathrm{~Hz}, 2 \mathrm{H})$.

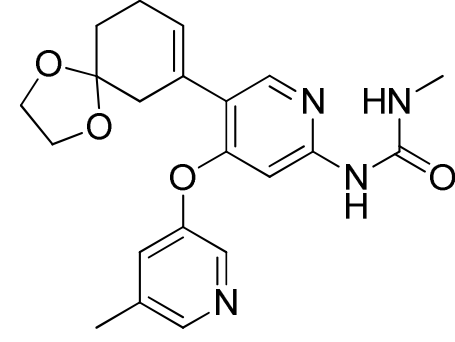

$16 \mathbf{a}$

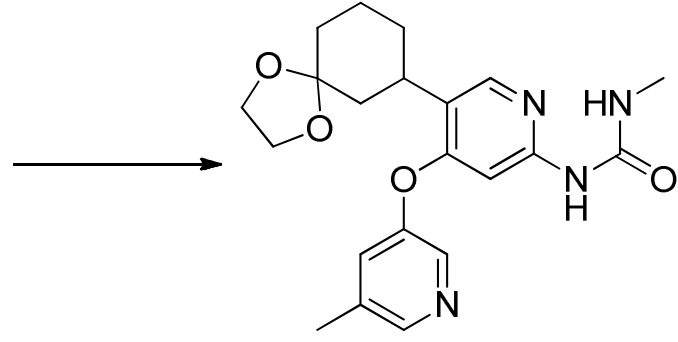

$16 \mathrm{~b}$

\section{1-Methyl-3-(4-((5-methylpyridin-3-yl)oxy)-5-(1,4-dioxaspiro[4.5]decan-7-yl)pyridin-2-}

yl)urea (16b). To a solution of compound 16a (410 mg, $1.00 \mathrm{mmol})$ in a 5:1 mixture of $\mathrm{MeOH}$ $(15 \mathrm{ml})$ and EtOAc $(3 \mathrm{ml})$ was added $10 \%$ palladium on carbon $(1.5 \mathrm{~g}, 14 \mathrm{mmol})$ and the slurry was stirred vigorously under hydrogen (balloon pressure) overnight. The slurry was then diluted with EtOAc, DCM and THF and filtered over a pad of diatomaceous earth. The filtrate was concentrated, and the crude material was adsorbed onto a plug of silica gel and purified by chromatography, eluting with $6 \%$ to $10 \% \mathrm{MeOH}$ in DCM, to give the title compound (16b) (140 $\mathrm{mg}, 0.35 \mathrm{mmol}, 34 \%$ yield). MS ESI (pos.) m/e: $399.1(\mathrm{M}+\mathrm{H}) .{ }^{1} \mathrm{H}$ NMR $\left(400 \mathrm{MHz}, \mathrm{CDCl}_{3}\right) \delta$ ppm 9.42 (s, $1 \mathrm{H}), 9.09$ (d, $J=3.91 \mathrm{~Hz}, 1 \mathrm{H}), 8.27$ (d, $J=0.98 \mathrm{~Hz}, 1 \mathrm{H}), 8.22(\mathrm{~d}, J=2.54 \mathrm{~Hz}, 1 \mathrm{H})$, $7.96(\mathrm{~s}, 1 \mathrm{H}), 7.16$ - $7.21(\mathrm{~m}, 1 \mathrm{H}), 6.15(\mathrm{~s}, 1 \mathrm{H}), 5.83$ - $5.91(\mathrm{~m}, 1 \mathrm{H}), 3.97(\mathrm{~s}, 4 \mathrm{H}), 2.76(\mathrm{~d}$, $J=4.70 \mathrm{~Hz}, 3 \mathrm{H}), 2.59-2.65$ (m, $2 \mathrm{H}), 2.36-2.44$ (m, $2 \mathrm{H}), 2.34$ (s, $3 \mathrm{H}), 1.78$ (t, J=6.55 Hz, 2 $\mathrm{H})$. 


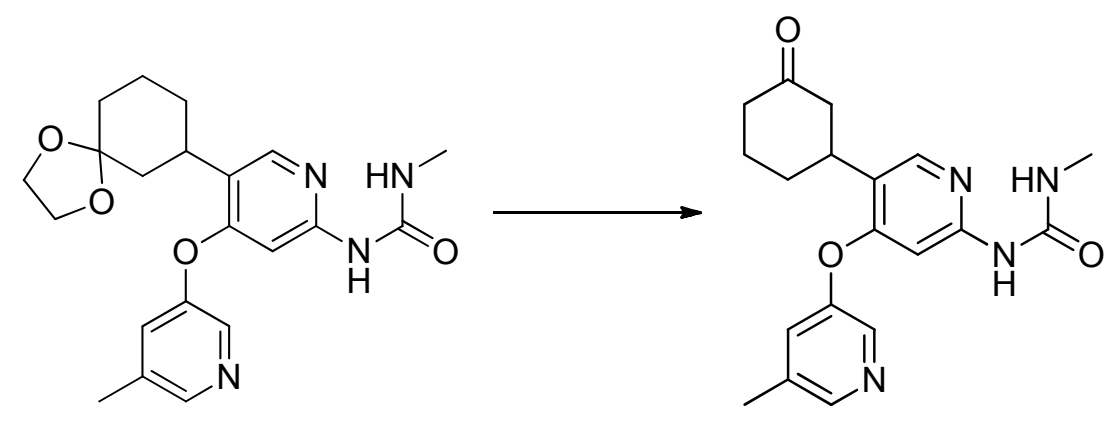

$16 b$

$16 \mathrm{c}$

\section{1-Methyl-3-(4-((5-methylpyridin-3-yl)oxy)-5-(3-oxocyclohexyl)pyridin-2-yl)urea (16c)}

Compound 16b (47 mg, $0.12 \mathrm{mmol})$ was dissolved in $\mathrm{EtOH}(1.2 \mathrm{ml})$ and $1.0 \mathrm{M} \mathrm{HCl}(0.35 \mathrm{ml}$, $0.35 \mathrm{mmol}$ ) was added. The resulting solution was stirred for 3.5 days. The reaction was concentrated, basified with saturated $\mathrm{NaHCO}_{3}$ then extracted with EtOAc $(3 \times 25 \mathrm{ml})$. The combined organic layers were washed with brine $(1 \times 20 \mathrm{ml})$ and dried over $\mathrm{MgSO}_{4}$. The crude material was adsorbed onto a plug of silica gel and purified by medium pressure chromatography, eluting with $6 \%$ to $10 \% \mathrm{MeOH}$ in DCM, to give the title compound (16c) (41 mg, 0.12 mmol, 98\% yield). MS ESI (pos.) m/e: $355.1(\mathrm{M}+\mathrm{H}) .{ }^{1} \mathrm{H}$ NMR (400 MHz, $\left.\mathrm{CDCl}_{3}\right) \delta$ ppm 9.07 (m, $J=3.9 \mathrm{~Hz}, 1 \mathrm{H}), 8.89$ (s, $1 \mathrm{H}), 8.34$ (d, $J=0.8 \mathrm{~Hz}, 1 \mathrm{H}), 8.25$ (d, $J=2.5 \mathrm{~Hz}, 1 \mathrm{H})$, 7.96 (s, 1 H), 7.16 - 7.26 (m, 1 H), 6.07 (s, 1 H), 3.25 - 3.43 (m, 1 H), 2.78 (d, J=4.9 Hz, 3 H), 2.57 - 2.70 (m, 2 H), 2.45 - 2.54 (m, 1 H), 2.39 - 2.44 (m, 1 H), 2.38 (s, 3 H), 2.07 - 2.22 (m, 2 H), 1.92 - 2.06 (m, $1 \mathrm{H}), 1.73-1.89(\mathrm{~m}, 1 \mathrm{H})$.

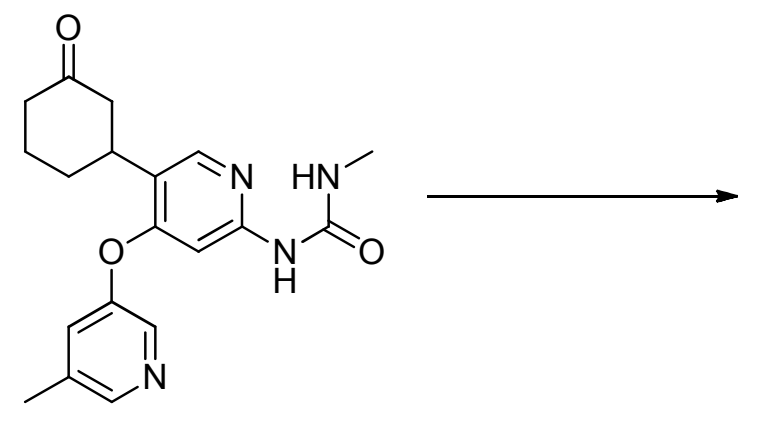

$16 \mathrm{c}$<smiles>CNC(=O)Nc1cc(Oc2cncc(C)c2)c(C2CCC[C@@H](O)C2)cn1</smiles> 


\section{1-(5-((1S,3S)-3-Hydroxycyclohexyl)-4-((5-methylpyridin-3-yl)oxy)pyridin-2-yl)-3-}

methylurea (16). Compound 16c (110 mg, $0.31 \mathrm{mmol})$ was dissolved in THF (2.5 ml) and cooled to $-78^{\circ} \mathrm{C}$. Lithium tri-sec-butyl(hydrido)borate (1.0 M in THF) (1.6 ml, $\left.1.6 \mathrm{mmol}\right)$ was then added dropwise and warmed to $-20^{\circ} \mathrm{C}$ over a period of $2.5 \mathrm{~h}$. The reaction was quenched with saturated aqueous $\mathrm{NH}_{4} \mathrm{Cl}$ solution and extracted with EtOAc $(3 \times 30 \mathrm{ml})$. The combined organic layers were washed with brine $(1 \times 20 \mathrm{ml})$, dried over $\mathrm{MgSO}_{4}$ and concentrated in vacuo. The crude material was adsorbed onto a plug of silica gel and purified by medium pressure chromatography, eluting with 5\% to $10 \% \mathrm{MeOH}$ in DCM, to give 1-(5-(trans-3hydroxycyclohexyl)-4-((5-methylpyridin-3-yl)oxy)pyridin-2-yl)-3-methylurea (75 mg, 0.21 mmol, 68\%). The racemic mixture was separated by supercritical fluid chromatography ( 2 x 25 cm OD-H column with $60 \mathrm{~mL} / \mathrm{min} 20 \% \mathrm{MeOH}\left(0.1 \% \mathrm{NH}_{4} \mathrm{OH}\right) / \mathrm{CO}_{2}$. Outlet pressure = 100 bar; wavelength $=220 \mathrm{~nm}$; injection volume $=0.4 \mathrm{~mL}, 7.5 \mathrm{mg} / \mathrm{mL} \mathrm{MeOH}$ ). Two enantiomers were obtained. The title compound (16) was the first isomer to elute under these conditions, and the structure was assigned arbitrarily. Mass spectrum $(\mathrm{ESI}) \mathrm{m} / \mathrm{z}=357.1(\mathrm{M}+\mathrm{H}) .{ }^{1} \mathrm{H} \mathrm{NMR}(400$

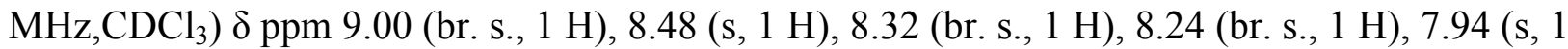
H), 7.21 (br. t, $J=1.0,1.0 \mathrm{~Hz}, 1 \mathrm{H}), 6.05$ (s, $1 \mathrm{H}$ ), 4.27 (br. t, $J=1.0,1.0 \mathrm{~Hz}, 1 \mathrm{H}$ ), 3.36 (tt, $J=12.3$, $3.1 \mathrm{~Hz}, 1 \mathrm{H}), 2.81(\mathrm{~d}, J=4.7 \mathrm{~Hz}, 3 \mathrm{H}), 2.37$ (s, $3 \mathrm{H}), 2.01$ (d, J=13.5 Hz, $1 \mathrm{H}), 1.90$ - 1.97 (m, 2 H), 1.73 - 1.89 (m, 4 H), 1.46 - $1.72(\mathrm{~m}, 2 \mathrm{H})$.

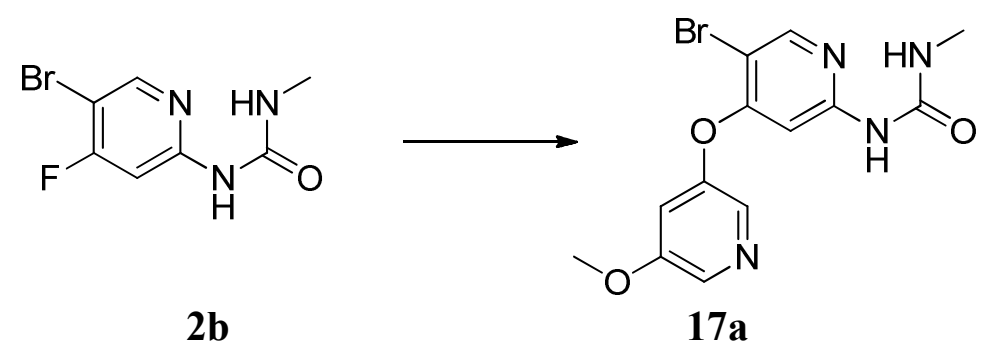

1-(5-Bromo-4-((5-methoxypyridin-3-yl)oxy)pyridin-2-yl)-3-methylurea (17a): A mixture of 5-methoxypyridin-3-ol (0.50 g, 4.00 mmol), 1-(5-bromo-4-fluoropyridin-2-yl)-3-methylurea (2b) $(0.99 \mathrm{~g}, 4.00 \mathrm{mmol})$ and cesium carbonate $(0.32 \mathrm{ml}, 4.00 \mathrm{mmol})$ in dimethylformamide $(13.0 \mathrm{ml})$ was allowed to stir under nitrogen at $85{ }^{\circ} \mathrm{C}$ over 60 hours. The mixture was cooled to ambient temperature then in an ice water bath. To this mixture was added $20 \mathrm{~mL}$ of saturated aqueous $\mathrm{NH}_{4} \mathrm{Cl}$ solution and $10 \mathrm{~mL}$ of water. The precipitate was collected and washed with water three times, dried under vacuum to give $(1.2 \mathrm{~g}, 3.3 \mathrm{mmol}, 83 \%)$ of the title compound (17a). ESI 
(pos.) m/e: $353.0(\mathrm{M}+\mathrm{H}) .{ }^{1} \mathrm{H}$ NMR $\left(500 \mathrm{MHz}, \mathrm{DMSO}-d_{6}\right) \delta \mathrm{ppm} 9.21(\mathrm{~s}, 1 \mathrm{H}), 8.34(\mathrm{~s}, 1 \mathrm{H})$, 8.30 (d, $J=2.4 \mathrm{~Hz}, 1 \mathrm{H}), 8.11$ (d, $J=2.2 \mathrm{~Hz}, 1 \mathrm{H}), 7.42$ (t, $J=2.4 \mathrm{~Hz}, 1 \mathrm{H}), 7.28$ - 7.40 (m, $1 \mathrm{H})$, 7.07 (s, $1 \mathrm{H}), 3.84-3.89$ (m, $3 \mathrm{H}), 2.64$ (d, $J=4.6 \mathrm{~Hz}, 3 \mathrm{H})$.

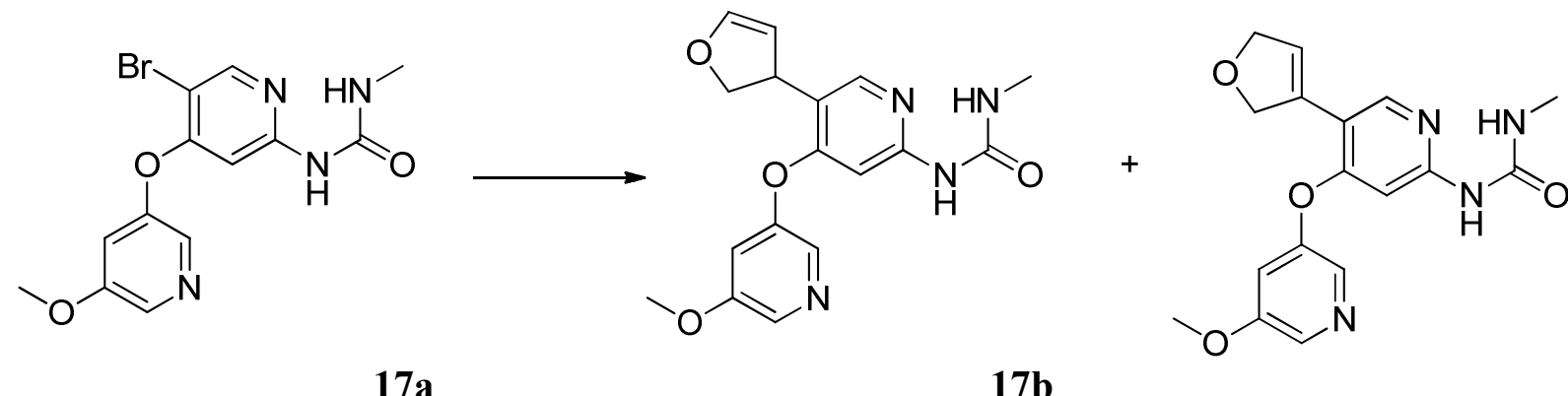

1-(5-(2,3-Dihydrofuran-3-yl)-4-((5-methoxypyridin-3-yl)oxy)pyridin-2-yl)-3-methylurea and 1-(5-(2,5-Dihydrofuran-2-yl)-4-((5-methoxypyridin-3-yl)oxy)pyridin-2-yl)-3methylurea (17b): A degassed mixture of 1-(5-bromo-4-((5-methoxypyridin-3-yl)oxy)pyridin2-yl)-3-methylurea 17a (260 mg, $0.74 \mathrm{mmol}$ ), bis(triphenylphosphine)palladium (II) dichloride (52 mg, $0.073 \mathrm{mmol}), \mathrm{NaHCO}_{3}(0.25 \mathrm{~g}, 2.90 \mathrm{mmol}), 2,5$-dihydrofuran $(0.52 \mathrm{~g}, 7.4 \mathrm{mmol})$ in 3.7 $\mathrm{mL}$ NMP was allowed to stir in a sealed tube at $130{ }^{\circ} \mathrm{C}$ overnight. The mixture was cooled to ambient temperature and was purified by medium pressure chromatography on a pre-packed silica gel column $(40 \mathrm{~g})$ using gradient $0-10 \%$ methanol in DCM to give the title compound (17b) ( $0.25 \mathrm{~g}, 0.74 \mathrm{mmol}, 100 \%$ yield) as a mixture of two isomers. The mixture was carried to next step without further purification and NMR characterization. ESI (pos.) m/e: $343.1(\mathrm{M}+\mathrm{H})^{+}$.<smiles>CNC(=O)Nc1cc(Oc2cncc(OC)c2)c(C2C=COC2)cn1</smiles>

$17 \mathbf{b}$

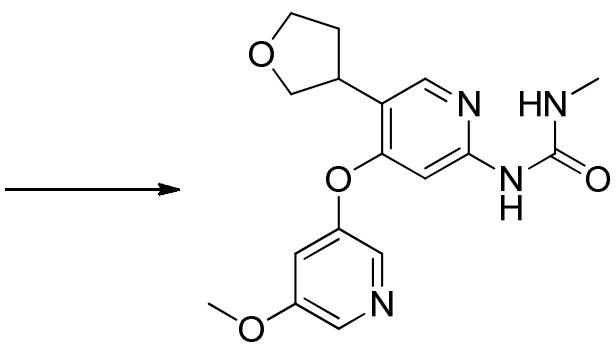

$17 \mathrm{c}$

1-(4-((5-Methoxypyridin-3-yl)oxy)-5-(tetrahydrofuran-3-yl)pyridin-2-yl)-3-methylurea

(17c): A mixture of 1-(5-(2,3-dihydrofuran-3-yl)-4-((5-methoxypyridin-3-yl)oxy)pyridin-2-yl)- 
3-methylurea and 1-(5-(2,5-dihydrofuran-2-yl)-4-((5-methoxypyridin-3-yl)oxy)pyridin-2-yl)-3methylurea (17b) (250 mg, $0.74 \mathrm{mmol}$ ), and palladium hydroxide, $20 \mathrm{wt} \% \mathrm{Pd}$ (dry basis) on carbon, wet $(52 \mathrm{mg}, 0.072 \mathrm{mmol})$ in methanol $(3.7 \mathrm{ml}, 0.74 \mathrm{mmol})$ was allowed to stir under a balloon of hydrogen at ambient temperature for 2.5 days. The mixture was concentrated and the residue was purified by medium pressure chromatography on a pre-packed silica gel column (24 g) using gradient $0-10 \%$ methanol/DCM to give a mixture which was purified again by reversephase preparative HPLC using a Phenomenex Luna column, 10 micron, C8(2), $100 \AA, 150$ x 30 $\mathrm{mm}, 0.1 \% \mathrm{TFA}$ in $\mathrm{CH}_{3} \mathrm{CN} / \mathrm{H}_{2} \mathrm{O}$, gradient $5 \%$ to $95 \%$ over $25 \mathrm{~min}$ to give $(28 \mathrm{mg}, 0.083 \mathrm{mmol}$, $11 \%$ yield) of the title compound $(\mathbf{1 7 c})$ as a TFA salt. ESI (pos.) m/e: $345.1(\mathrm{M}+\mathrm{H})^{+} .{ }^{1} \mathrm{H}$ NMR $\left(400 \mathrm{MHz}, \mathrm{CDCl}_{3}\right) \delta$ ppm 12.63 (br. s., $\left.1 \mathrm{H}\right), 8.38$ (d, $\left.J=2.54 \mathrm{~Hz}, 1 \mathrm{H}\right), 8.22(\mathrm{~d}, J=2.15 \mathrm{~Hz}, 1 \mathrm{H}$ ), 7.92 (s, 1 H), 7.27 (br. s, 1 H), 7.25 (t, J=2.45 Hz, 1 H), 6.81 (s, 1 H), 4.08 - 4.13 (m, 1 H), 4.02 4.07 (m, $1 \mathrm{H}), 3.93$ - 4.00 (m, $4 \mathrm{H}), 3.88$ (dd, $J=8.90,4.60 \mathrm{~Hz}, 1 \mathrm{H}), 3.72$ - 3.84 (m, $1 \mathrm{H}), 2.80$ (d, $J=4.50 \mathrm{~Hz}, 3 \mathrm{H}), 2.48(\mathrm{dt}, 1 \mathrm{H}), 1.98-2.08(\mathrm{~m}, 1 \mathrm{H})$.

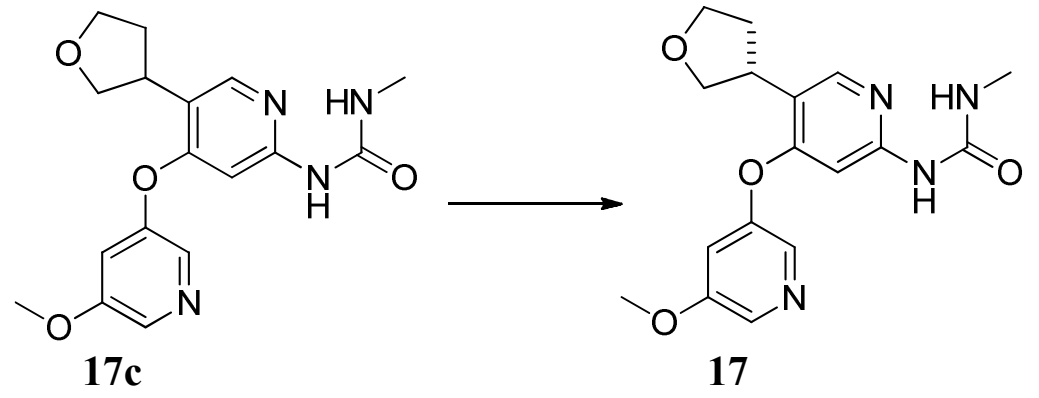

(R)-1-(4-((5-Methoxypyridin-3-yl)oxy)-5-(tetrahydrofuran-3-yl)pyridin-2-yl)-3-methylurea

(17): The racemic mixture of $\mathbf{1 7} \mathbf{c}$ was separated by supercritical fluid chromatography with the following conditions: $250 \times 30 \mathrm{~mm}$ OJ-H column with $24 \mathrm{~g} / \mathrm{min} \mathrm{MeOH}+(20 \mathrm{mM} \mathrm{NH} 3)+96$ $\mathrm{g} / \mathrm{min} \mathrm{CO}_{2}$ on Thar $350 \mathrm{SFC}$. Outlet pressure $=100$ bar; Temp. $=19 \mathrm{C}$; Wavelength $=220 \mathrm{~nm}$. Used $1.0 \mathrm{~mL}$ injections of $26 \mathrm{mg} / 5 \mathrm{~mL}(5.2 \mathrm{mg} / \mathrm{mL})$ sample solution in $\mathrm{MeOH}$, i.e. 5.2 $\mathrm{mg} /$ injection. Run time $=7 \mathrm{~min}$, Cycle time $=4 \mathrm{~min}$. The title compound (17) was the first peak to elute off chiral column. Stereochemistry was arbitrarily assigned. ESI (pos.) m/e: 345.2 $(\mathrm{M}+\mathrm{H})^{+} .{ }^{1} \mathrm{H}$ NMR $\left(400 \mathrm{MHz}, \mathrm{CDCl}_{3}\right) \delta$ ppm 9.08 (br. s., $\left.1 \mathrm{H}\right), 8.62(\mathrm{~s}, 1 \mathrm{H}), 8.23(\mathrm{~d}, J=2.35 \mathrm{~Hz}$, $1 \mathrm{H}), 8.04-8.06(\mathrm{~m}, 2 \mathrm{H}), 6.94(\mathrm{t}, J=2.35 \mathrm{~Hz}, 1 \mathrm{H}), 6.14(\mathrm{~s}, 1 \mathrm{H}), 4.16$ (dd, $J=8.31,7.34 \mathrm{~Hz}, 1$ H), 4.05 (td, $J=8.22,5.28 \mathrm{~Hz}, 1 \mathrm{H}), 3.91-3.98(\mathrm{~m}, 1 \mathrm{H}), 3.88(\mathrm{~s}, 3 \mathrm{H}), 3.78-3.84(\mathrm{~m}, 1 \mathrm{H}), 3.66$ 
(quin, $J=7.43 \mathrm{~Hz}, 1 \mathrm{H}), 2.82(\mathrm{~d}, J=4.70 \mathrm{~Hz}, 3 \mathrm{H}), 2.36(\mathrm{dt}, 1 \mathrm{H}), 2.10(\mathrm{dq}, J=12.30,7.51 \mathrm{~Hz}, 1$ $\mathrm{H})$.

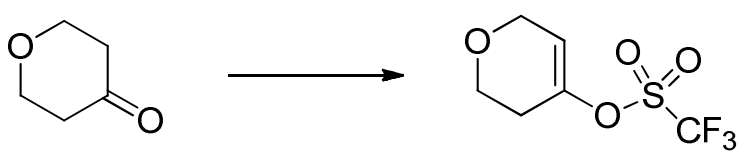

$18 \mathbf{a}$

3,6-Dihydro-2H-pyran-4-yl trifluoromethanesulfonate (18a): To a $-78{ }^{\circ} \mathrm{C}$ solution of tetrahydropyran-4-one $(2.0 \mathrm{~mL}, 22 \mathrm{mmol})$ in dry THF $(47 \mathrm{~mL})$ was added LDA, $2.0 \mathrm{M}$ in Heptane/ THF/ Ethylbenzene $(13 \mathrm{~mL}, 25 \mathrm{mmol})$ dropwise under nitrogen. Stirring was continued for $\sim 45$ minutes at the same temperature to afford a cloudy yellow mixture, to which a solution of N-phenyl-bis(trifluoromethanesulfonimide) (8.5 g, $24 \mathrm{mmol})$ in dry THF (24 mL) was added dropwise via syringe. The cooling bath was removed, and the mixture was stirred at room temperature. After three hours, the mixture was concentrated then diluted with water. After extracting three times with hexanes, the organics were combined and washed with brine. After drying over anhydrous magnesium sulfate and subsequent filtration, the solvent was removed under reduced pressure. The residue was then purified by medium pressure chromatography (silica gel, eluted with gradient $0 \%-5 \%$ ethyl acetate/hexanes) to provide the title compound (18a) $\left(1.9 \mathrm{~g}, 8.3 \mathrm{mmol}, 38 \%\right.$ yield) as an oil. ${ }^{1} \mathrm{H} \mathrm{NMR}\left(400 \mathrm{MHz}, \mathrm{CDCl}_{3}\right) \delta \mathrm{ppm}$ 5.82 (tt, $J=2.9,1.4 \mathrm{~Hz}, 1 \mathrm{H}), 4.26$ (q, $J=2.7 \mathrm{~Hz}, 2 \mathrm{H}), 3.91$ (m, $2 \mathrm{H}), 2.49$ (m, $2 \mathrm{H})$.

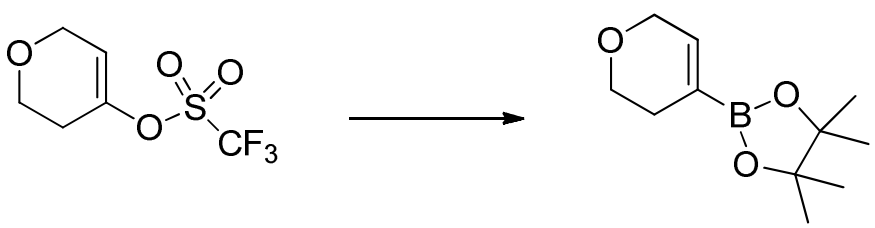

$18 \mathbf{a}$

$18 \mathrm{~b}$

2-(3,6-Dihydro-2H-pyran-4-yl)-4,4,5,5-tetramethyl-1,3,2-dioxaborolane (18b): A mixture of 3,6-dihydro-2H-pyran-4-yl trifluoromethanesulfonate (18a) $\quad\left(\begin{array}{lllll}0.54 & \mathrm{~g}, & 2.30 & \mathrm{mmol}\end{array}\right)$, bis(pinacolato)diboron $(0.74 \mathrm{~g}, 2.90 \mathrm{mmol}), 1,1^{\prime}$-bis(diphenylphosphino)ferrocene-palladium (II) dichloride adduct $(0.19 \mathrm{~g}, 0.23 \mathrm{mmol})$, and potassium acetate $(0.92 \mathrm{~g}, 9.4 \mathrm{mmol})$ in dry 1,4dioxane $(10 \mathrm{~mL})$ was degassed by nitrogen. The mixture was heated to $90{ }^{\circ} \mathrm{C}$. After 19 hours, the reaction was cooled to room temperature then filtered. After concentration, the residue was 
purified by medium pressure chromatography (silica, $0-5 \%$ ethyl acetate in hexanes) to yield the title compound (18b) as a white solid $\left(0.19 \mathrm{~g}, 0.90 \mathrm{mmol}, 38 \%\right.$ yield). ${ }^{1} \mathrm{H}$ NMR (400 MHz, $\left.\mathrm{CDCl}_{3}\right) \delta$ ppm 6.49 (t, $\left.J=2.0 \mathrm{~Hz}, 1 \mathrm{H}\right), 4.15$ (q, $\left.J=2.7 \mathrm{~Hz}, 2 \mathrm{H}\right), 3.72$ (t, $\left.J=5.4 \mathrm{~Hz}, 2 \mathrm{H}\right), 2.19$ (tq, $J=5.1,2.7 \mathrm{~Hz}, 2 \mathrm{H}), 1.23(\mathrm{~s}, 12 \mathrm{H})$.

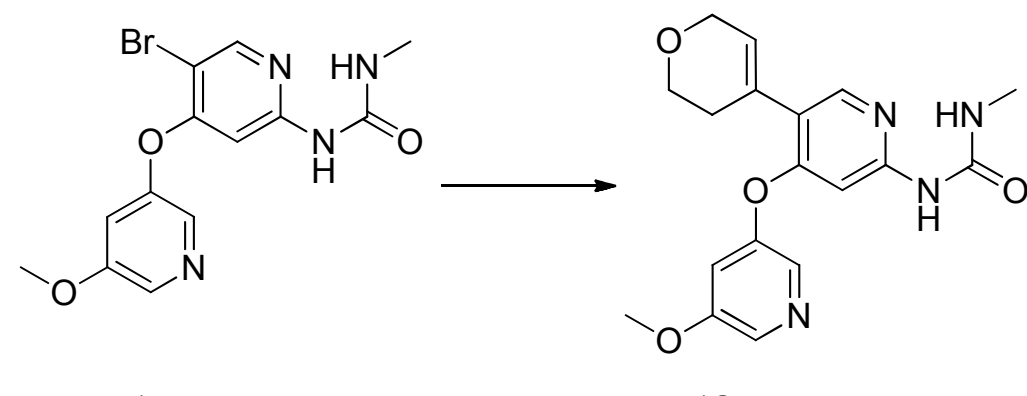

$17 \mathbf{a}$

18

\section{1-(5-(3,6-Dihydro-2H-pyran-4-yl)-4-((5-methoxypyridin-3-yl)oxy)pyridin-2-yl)-3-}

methylurea (18): 2-(3,6-dihydro-2H-pyran-4-yl)-4,4,5,5-tetramethyl-1,3,2-dioxaborolane (18b) (600 mg, $2.8 \mathrm{mmol})$, tricyclohexylphosphine $(79 \mathrm{mg}, 0.28 \mathrm{mmol})$, 1-(5-bromo-4-((5methoxypyridin-3-yl)oxy)pyridin-2-yl)-3-methylurea (17a) (500 $\mathrm{mg}, 1.40 \mathrm{mmol}$ ) and $\operatorname{Pd}_{2}(\mathrm{dba})_{3}$ $(130 \mathrm{mg}, 0.14 \mathrm{mmol})$ were slurried in dioxane $(9.5 \mathrm{ml})$ and then sparged with argon. Potassium carbonate (1.3 M soln.) ( $2.9 \mathrm{ml}, 3.8 \mathrm{mmol})$ was added and the reaction mixture was heated to 90 ${ }^{\circ} \mathrm{C}$ for 1.5 hours. The reaction was cooled and concentrated to a reduced volume. This residue was then taken up in water $(30 \mathrm{~mL})$ and extracted with dichloromethane $(2 \times 60 \mathrm{~mL})$. The combined organic layers were dried over magnesium sulfate and concentrated. The crude product was purified by medium pressure chromatography (silica, 2.5 to $10 \% \mathrm{MeOH}$ in $\mathrm{DCM}$ ) to provide $270 \mathrm{mg}$ of the title compound (18) which was contaminated with $\sim 10-15 \%$ debrominated starting material, but was used in next step without further purification.

To obtain pure material for characterization and assay purposes, a small scale reaction was run following the same procedure. The crude material was purified by reverse-phase preparative HPLC using a Phenomenex Luna column, 10 micron, C8(2), $100 \AA, 150$ x 30 mm, 0.1\% TFA in $\mathrm{CH}_{3} \mathrm{CN} / \mathrm{H}_{2} \mathrm{O}$, gradient $5 \%$ to $95 \%$ over 25 min to provide impure material which was then free based and purified again by medium pressure chromatography (silica, 0 to $10 \% \mathrm{MeOH} / \mathrm{DCM}$ ) to provide the title compound (18) (12 mg). ESI (pos.) m/e: $357.2(\mathrm{M}+\mathrm{H})^{+} .{ }^{1} \mathrm{H}$ NMR (400 MHz, $\left.\mathrm{CDCl}_{3}\right) \delta$ ppm 9.06 (br. s., $\left.1 \mathrm{H}\right), 8.75$ (s, $\left.1 \mathrm{H}\right), 8.21$ (d, $\left.J=2.15 \mathrm{~Hz}, 1 \mathrm{H}\right), 8.04$ (d, $J=2.35 \mathrm{~Hz}, 1$ 
H), $8.00(\mathrm{~s}, 1 \mathrm{H}), 6.92$ (t, $J=2.35 \mathrm{~Hz}, 1 \mathrm{H}), 6.18(\mathrm{~s}, 1 \mathrm{H}), 5.94-5.98$ (m, $1 \mathrm{H}), 4.30$ (q, $J=2.74 \mathrm{~Hz}$, $2 \mathrm{H}), 3.86$ - 3.90 (m, $5 \mathrm{H}), 2.83$ (d, $J=4.69 \mathrm{~Hz}, 3 \mathrm{H}), 2.49-2.55$ (m, $2 \mathrm{H})$.

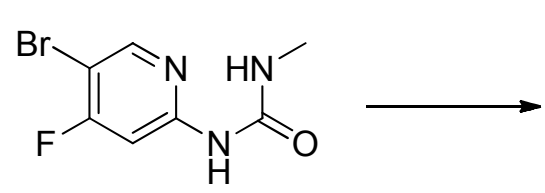

2b

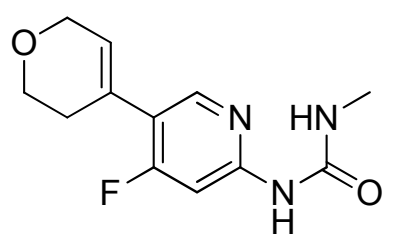

$19 \mathbf{a}$

1-(5-(3,6-Dihydro-2H-pyran-4-yl)-4-fluoropyridin-2-yl)-3-methylurea (19a): 1-(5-bromo-4fluoropyridin-2-yl)-3-methylurea (2a) (1.00 g, $4.00 \mathrm{mmol}$ ), 2-(3,6-dihydro-2H-pyran-4-yl)4,4,5,5-tetramethyl-1,3,2-dioxaborolane (18b) (1.3 g, $6.1 \mathrm{mmol})$, tricyclohexylphosphine $(0.23 \mathrm{~g}$, $0.81 \mathrm{mmol})$, and tris(dibenzylideneacetone)dipalladium (0) $(0.37 \mathrm{~g}, 0.40 \mathrm{mmol})$ were added to a flask with 1,4-dioxane $(40 \mathrm{ml})$ and sparged with argon. Aqueous $1.3 \mathrm{M} \mathrm{K}_{3} \mathrm{PO}_{4}(8.4 \mathrm{ml}, 11$ mmol) was added by syringe. The resulting reaction was heated to $80^{\circ} \mathrm{C}$. After 17 hours, the reaction was cooled to room temperature then concentrated under reduced pressure. The residue was diluted with water $(60 \mathrm{~mL})$ then extracted three times with dichloromethane $(3 \times 75 \mathrm{~mL})$. The organics were pooled then dried over anhydrous magnesium sulfate. After filtration and concentration, the residue was purified by medium pressure chromatography (silica, 25-100\% of ethyl acetate in dichloromethane) to give the title compound (19a) (850 mg, $3.4 \mathrm{mmol}, 83 \%$ yield). ESI (pos.) m/e: $252.1(\mathrm{M}+\mathrm{H})^{+} .{ }^{1} \mathrm{H}$ NMR $\left(400 \mathrm{MHz}, \mathrm{CDCl}_{3}\right) \delta$ ppm 9.70 (br. s., $\left.1 \mathrm{H}\right), 9.07$ (br. s., $1 \mathrm{H}), 8.07$ (d, $J=10.37 \mathrm{~Hz}, 1 \mathrm{H}), 6.69$ (d, $J=12.13 \mathrm{~Hz}, 1 \mathrm{H}), 6.04$ (tt, $J=2.81,1.49 \mathrm{~Hz}, 1$ H), 4.32 (q, $J=2.74 \mathrm{~Hz}, 2 \mathrm{H}), 3.92$ (t, $J=5.48 \mathrm{~Hz}, 2 \mathrm{H}), 2.98$ (d, $J=4.70 \mathrm{~Hz}, 3 \mathrm{H}), 2.45-2.51$ (m, 2 $\mathrm{H})$.

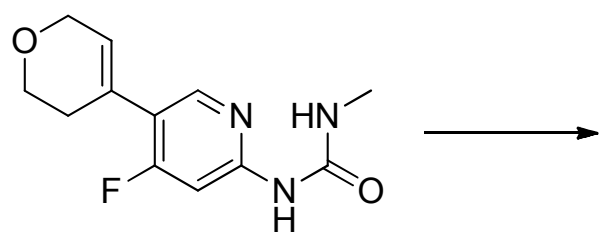

19a

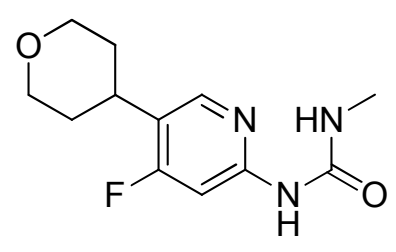

19b

1-(4-Fluoro-5-(tetrahydro-2H-pyran-4-yl)pyridin-2-yl)-3-methylurea $\quad$ (19b): $\quad$ 1-(5-(3,6dihydro-2H-pyran-4-yl)-4-fluoropyridin-2-yl)-3-methylurea (19a) (850 mg, $3.4 \mathrm{mmol}$ ) was slurried in $67 \mathrm{~mL}$ of a 5:1 MeOH : EtOAc mixture. $10 \% \mathrm{Pd} / \mathrm{C}(1.7 \mathrm{~g}, 16 \mathrm{mmol})$ was added and 
the reaction flask was flushed with hydrogen and kept under balloon pressure for 18 hours. The reaction vessel was then flushed with nitrogen for 1.5 hours to deactivate the catalyst. The black slurry was filtered over a pad of diatomaceous earth and washed with EtOAc, DCM and MeOH mixtures. The filtrate was then concentrated to give the title compound (19b) $(770 \mathrm{mg}, 3.00$ mmol, 90\% yield) with excellent purity and was used without further purification. ESI (pos.) m/e: $254.1(\mathrm{M}+\mathrm{H})^{+} .{ }^{1} \mathrm{H}$ NMR $\left(400 \mathrm{MHz}, \mathrm{DMSO}-d_{6}\right) \delta$ ppm 9.30 (s, $\left.1 \mathrm{H}\right), 8.12$ (d, $J=10.76 \mathrm{~Hz}, 1$ H), 7.54 (br. s., $1 \mathrm{H}), 7.25$ (d, $J=13.11 \mathrm{~Hz}, 1 \mathrm{H}), 3.93$ (dd, $J=10.86,3.62 \mathrm{~Hz}, 2 \mathrm{H}), 3.43$ (td, $J=11.64,2.15 \mathrm{~Hz}, 2 \mathrm{H}), 2.93$ (tt, $J=11.91,3.84 \mathrm{~Hz}, 1 \mathrm{H}), 2.70$ (d, $J=4.50 \mathrm{~Hz}, 3 \mathrm{H}), 1.59-1.81$ (m, $4 \mathrm{H})$.

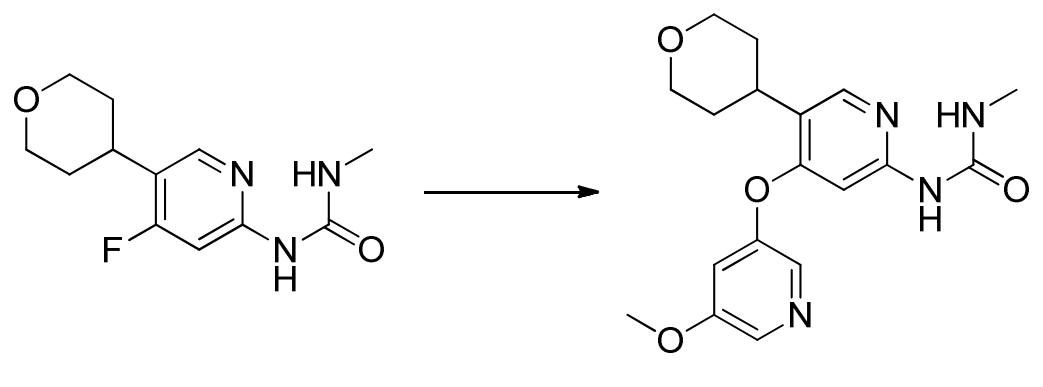

19b

19

\section{1-(4-((5-methoxypyridin-3-yl)oxy)-5-(tetrahydro-2H-pyran-4-yl)pyridin-2-yl)-3-}

methylurea (19): 1-(4-fluoro-5-(tetrahydro-2H-pyran-4-yl)pyridin-2-yl)-3-methylurea (19b) (77 $\mathrm{mg}, 0.30 \mathrm{mmol})$, 5-methoxypyridin-3-ol $(76 \mathrm{mg}, 0.61 \mathrm{mmol})$, and cesium carbonate (200 $\mathrm{mg}$, $0.61 \mathrm{mmol})$ were combined in DMSO $(2.2 \mathrm{ml})$ and heated to $100{ }^{\circ} \mathrm{C}$ for one hour. The reaction slurry was filtered. The crude material was purified by reverse-phase preparative HPLC using a Phenomenex Gemini column, 10 micron, $\mathrm{C} 18,100 \AA$, $150 \times 30 \mathrm{~mm}, 0.1 \% \mathrm{TFA}$ in $\mathrm{CH}_{3} \mathrm{CN} / \mathrm{H}_{2} \mathrm{O}$, gradient $5 \%$ to $90 \%$ over 20 min to provide the TFA salt of the desired product that contained some impurities. The salt was then repurified by medium pressure chromatography (silica, 2.5 to 10\% $2 \mathrm{M}$ ammonia in methanol/DCM) to give the title compound (19) (7.0 $\mathrm{mg}, 0.022 \mathrm{mmol}$, $6.4 \%$ yield) as an off-white solid. ESI (pos.) m/e: $359.0(\mathrm{M}+\mathrm{H})^{+} \cdot{ }^{1} \mathrm{H}$ NMR $\left(400 \mathrm{MHz}, \mathrm{CDCl}_{3}\right) \delta$ ppm 9.10 (br. q, $J=1.0,1.0,1.0 \mathrm{~Hz}, 1 \mathrm{H}), 8.24$ (d, $J=2.3 \mathrm{~Hz}, 1 \mathrm{H}), 8.05$ (d, $J=2.3 \mathrm{~Hz}, 1 \mathrm{H}), 8.01$ $(\mathrm{s}, 1 \mathrm{H}), 7.91(\mathrm{~s}, 1 \mathrm{H}), 6.93(\mathrm{t}, J=2.3 \mathrm{~Hz}, 1 \mathrm{H}), 6.02(\mathrm{~s}, 1 \mathrm{H}), 4.10(\mathrm{dd}, J=11.3,4.1 \mathrm{~Hz}, 2 \mathrm{H}), 3.88$ $(\mathrm{s}, 3 \mathrm{H}), 3.56$ (td, $J=11.6,2.2 \mathrm{~Hz}, 2 \mathrm{H}), 3.13$ (tt, $J=11.6,3.9 \mathrm{~Hz}, 1 \mathrm{H}), 2.86$ (d, J=4.9 Hz, $3 \mathrm{H}$ ), $1.86-1.98$ (m, $2 \mathrm{H}), 1.77$ - $1.86(\mathrm{~m}, 2 \mathrm{H})$. 


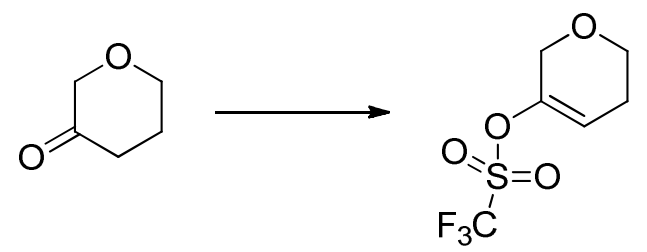

20a

5,6-Dihydro-2H-pyran-3-yl trifluoromethanesulfonate (20a): Diisopropylamine (12 ml, 86 mmol) was dissolved in THF $(120 \mathrm{~mL})$ and cooled to $-78{ }^{\circ} \mathrm{C}$. N-butyllithium (1.6 M in hexanes) (56 ml, $89 \mathrm{mmol}$ ) was added dropwise at $-78^{\circ} \mathrm{C}$ and stirred for 25 minutes to form the LDA solution. The mixture was raised out of the dry ice bath for 25 minutes then resubmerged. Dihydro-2H-pyran-3(4H)-one (7.5 g, $74 \mathrm{mmol})$ was then dissolved in THF $(80 \mathrm{~mL})$ and added slowly to the LDA solution at $-78{ }^{\circ} \mathrm{C}$ and stirred for 45 minutes. N-phenylbis(trifluoromethanesulfonimide) $(29 \mathrm{~g}, 82 \mathrm{mmol})$ dissolved in THF $(100 \mathrm{~mL})$ was added slowly and the reaction mixture was allowed to stir overnight while warming to room temperature. The reaction mixture was quenched with water and the mixture was extracted with hexanes $(3 \times 500$ $\mathrm{mL}$ ). The combined organic layers were washed with brine and dried over magnesium sulfate. The crude product was then purified by medium pressure chromatography (silica, 0 to $20 \%$ ethyl acetate/hexanes) to provide the title compound 20a (6.2 g, $27 \mathrm{mmol}, 36 \%$ yield) mixed about $10 \%$ of its geometric isomer 3,4-dihydro-2H-pyran-5-yl trifluoromethanesulfonate. This material was used in the next step without further purification or characterization.

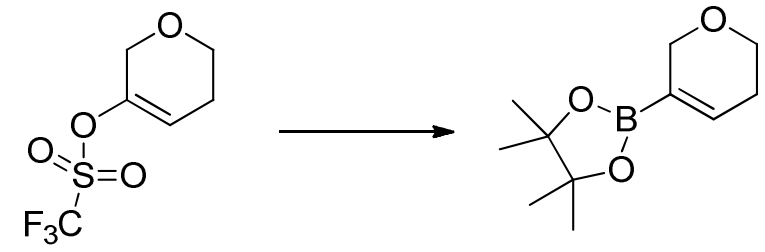

20a

20b

2-(5,6-dihydro-2H-pyran-3-yl)-4,4,5,5-tetramethyl-1,3,2-dioxaborolane (20b): 5,6-dihydro2H-pyran-3-yl trifluoromethanesulfonate (20a) (6.2 g, $27 \mathrm{mmol})$ (mixture of isomers), bis(pinacolato)diboron $(8.1 \mathrm{~g}, 32 \mathrm{mmol}), \mathrm{PdCl}_{2}(\mathrm{dppf})-\mathrm{CH}_{2} \mathrm{Cl}_{2}$ adduct $(2.2 \mathrm{~g}, 2.7 \mathrm{mmol})$, and potassium acetate $(11 \mathrm{~g}, 110 \mathrm{mmol})$ were added to a flask with dioxane $(89 \mathrm{ml})$. This mixture was heated at $80{ }^{\circ} \mathrm{C}$ overnight. The reaction mixture was cooled and then filtered over diatomaceous earth and washed with ethyl acetate. The filtrate was concentrated and then purified by medium pressure chromatography (silica, 0 to 20\% EtOAc : hexanes) to give 2-(5,6dihydro-2H-pyran-3-yl)-4,4,5,5-tetramethyl-1,3,2-dioxaborolane (20b) (4.7 g, $22 \mathrm{mmol}, 83 \%$ 
yield). ${ }^{1} \mathrm{H} \mathrm{NMR}\left(400 \mathrm{MHz}, \mathrm{CDCl}_{3}\right) \delta=6.68(\mathrm{tt}, J=2.0,3.8 \mathrm{~Hz}, 1 \mathrm{H}), 4.27(\mathrm{q}, J=2.8 \mathrm{~Hz}, 2 \mathrm{H})$, 3.80 (t, $J=5.6 \mathrm{~Hz}, 2 \mathrm{H}), 2.23$ (tdt, $J=2.9,3.8,5.6 \mathrm{~Hz}, 2 \mathrm{H}), 1.28$ (s, $12 \mathrm{H}$ ).

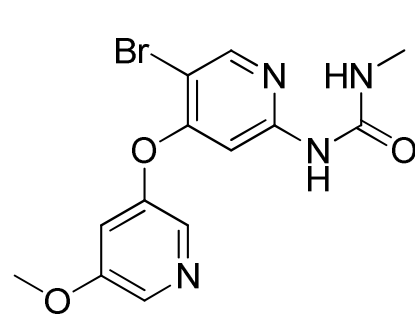

$17 \mathbf{a}$

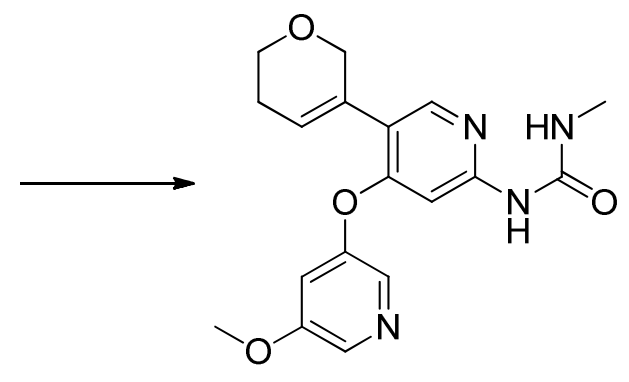

20

\section{1-(5-(5,6-Dihydro-2H-pyran-3-yl)-4-((5-methoxypyridin-3-yl)oxy)pyridin-2-yl)-3-}

methylurea (20): 2-(5,6-dihydro-2H-pyran-3-yl)-4,4,5,5-tetramethyl-1,3,2-dioxaborolane (20b) (420 mg, $2.00 \mathrm{mmol})$, tricyclohexylphosphine (56 mg, $0.20 \mathrm{mmol})$, 1-(5-bromo-4-((5methoxypyridin-3-yl)oxy)pyridin-2-yl)-3-methylurea (17a) (350 mg, $0.99 \mathrm{mmol})$ and $\operatorname{Pd}_{2}\left(\mathrm{dba}_{3}\right.$ (91 $\mathrm{mg}, 0.10 \mathrm{mmol})$ were slurried in 1,4-dioxane $(6.0 \mathrm{ml})$ and then sparged with argon. The $1.3 \mathrm{M} \mathrm{K}_{3} \mathrm{PO}_{4}(2.1 \mathrm{ml}, 2.7 \mathrm{mmol})$ was then added and the reaction mixture was heated to $90{ }^{\circ} \mathrm{C}$ for one hour. The reaction was cooled and then concentrated to a reduced volume. This residue was then taken up in water $(30 \mathrm{~mL})$ and extracted with dichloromethane $(2 \times 80 \mathrm{~mL})$. The combined organic layers were dried over magnesium sulfate and concentrated. The crude product was purified by medium pressure chromatography (silica, 2.5 to $10 \% \mathrm{MeOH} / \mathrm{DCM}$ ) to give desired product with only $\sim 85 \%$ purity. This mixture was purified further by reverse-phase preparative HPLC using a Phenomenex Luna column, 5 micron, C8(2), $100 \AA, 150 \times 21.2 \mathrm{~mm}, 0.1 \%$ TFA in $\mathrm{CH}_{3} \mathrm{CN} / \mathrm{H}_{2} \mathrm{O}$, gradient $5 \%$ to $95 \%$ over $25 \mathrm{~min}$ to provide the title compound (20) (180 mg, 0.51 mmol, 51\% yield). ESI (pos.) m/e: $357.1(\mathrm{M}+\mathrm{H})^{+} .{ }^{1} \mathrm{H}$ NMR (400 MHz, DMSO- $\left.d_{6}\right) \delta \mathrm{ppm} 9.11$ (s, $1 \mathrm{H}), 8.25(\mathrm{~d}, J=2.35 \mathrm{~Hz}, 1 \mathrm{H}), 8.02-8.07(\mathrm{~m}, 2 \mathrm{H}), 7.68(\mathrm{~d}, J=3.91 \mathrm{~Hz}, 1 \mathrm{H}), 7.32(\mathrm{~s}, 1 \mathrm{H})$, $6.84(\mathrm{~s}, 1 \mathrm{H}), 6.05(\mathrm{dt}, J=5.05 \mathrm{~Hz}, 1 \mathrm{H}), 4.27-4.38(\mathrm{~m}, 2 \mathrm{H}), 3.85(\mathrm{~s}, 3 \mathrm{H}), 3.72(\mathrm{t}, J=5.67 \mathrm{~Hz}, 2$ $\mathrm{H}), 2.65$ (d, $J=4.70 \mathrm{~Hz}, 3 \mathrm{H}), 2.19-2.27$ (m, $2 \mathrm{H})$. 


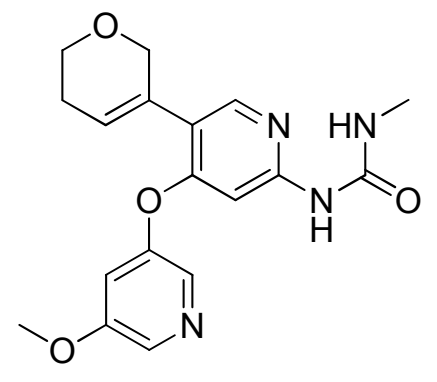

20

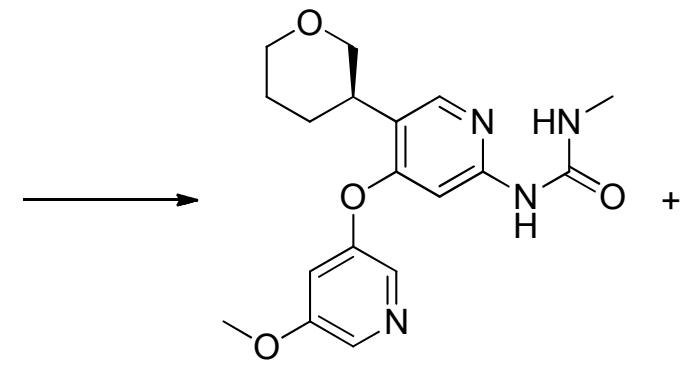

21

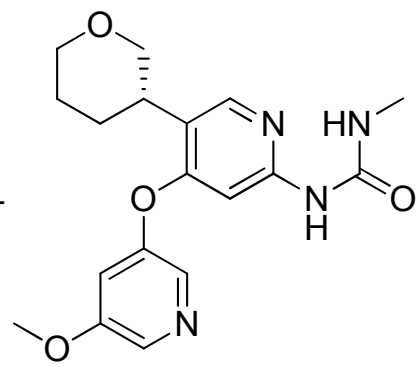

22

(R)-1-(4-((5-Methoxypyridin-3-yl)oxy)-5-(tetrahydro-2H-pyran-3-yl)pyridin-2-yl)-3-

methylurea (21): 1-(5-(5,6-dihydro-2H-pyran-3-yl)-4-((5-methoxypyridin-3-yl)oxy)pyridin-2yl)-3-methylurea (20) (390 mg, $1.10 \mathrm{mmol})$ was dissolved in a 5:1 ratio of $\mathrm{MeOH}(25 \mathrm{ml})$ and EtOAc $(5 \mathrm{ml}) .10 \% \mathrm{Pd} / \mathrm{C}(1.20 \mathrm{~g}, 11.0 \mathrm{mmol})$ was added and the reaction flask was flushed with hydrogen then kept under balloon pressure with vigorous stirring overnight. Another $600 \mathrm{mg}$ of $10 \% \mathrm{Pd} / \mathrm{C}$ was added and the slurry was stirred vigorously under hydrogen over 22 hours. The reaction was then flushed with nitrogen and diluted with EtOAc. The reaction was filtered over a pad of diatomaceous earth and washed with EtOAc/MeOH mixture, DCM and THF in an attempt to free product from catalyst. This resulted in a fair recovery of racemic 1-(4-((5methoxypyridin-3-yl)oxy)-5-(tetrahydro-2H-pyran-3-yl)pyridin-2-yl)-3-methylurea (290 mg, $0.81 \mathrm{mmol}, 74 \%$ yield). The racemic material was purified by supercritical fluid chromatography that resulted in isolation of two pure enantiomers. Separation condition: 250 x $30 \mathrm{~mm}$ Lux 2 column with $78 \mathrm{~g} / \mathrm{min} \mathrm{MeOH}+\left(20 \mathrm{mM} \mathrm{NH}_{3}\right)+42 \mathrm{~g} / \mathrm{min} \mathrm{CO}_{2}$ on Thar 350 SFC. Outlet pressure $=100$ bar; Temp. $=22^{\circ} \mathrm{C}$; Wavelength $=220 \mathrm{~nm}$. Used $1.5 \mathrm{~mL}$ injections of $290 \mathrm{mg} / 20 \mathrm{~mL}(14.5 \mathrm{mg} / \mathrm{mL})$ sample solution in $\mathrm{MeOH}$, i.e. $21.8 \mathrm{mg} /$ injection. Run time $=$ $14 \mathrm{~min}$, Cycle time= $12 \mathrm{~min}$. The title compound, (R)-1-(4-((5-methoxypyridin-3-yl)oxy)-5(tetrahydro-2H-pyran-3-yl)pyridin-2-yl)-3-methylurea (21) (73 mg, $0.20 \mathrm{mmol}, 19 \%$ yield), was the first peak off chiral column. Stereochemistry was assigned arbitrarily. ESI (pos.) m/e: 359.2 $(\mathrm{M}+\mathrm{H})^{+} .{ }^{1} \mathrm{H}$ NMR $\left(400 \mathrm{MHz}, \mathrm{DMSO}-d_{6}\right) \delta \mathrm{ppm} 9.02(\mathrm{~s}, 1 \mathrm{H}), 8.26(\mathrm{~d}, J=2.54 \mathrm{~Hz}, 1 \mathrm{H}), 8.09$ (s, $1 \mathrm{H}), 8.06$ (d, J=2.15 Hz, $1 \mathrm{H}$ ), 7.80 (br. s., $1 \mathrm{H}$ ), 7.34 (t, $J=2.45 \mathrm{~Hz}, 1 \mathrm{H}), 6.76$ (s, $1 \mathrm{H}), 3.83$ $3.96(\mathrm{~m}, 5 \mathrm{H}), 3.34-3.46$ (m, $2 \mathrm{H}), 3.04-3.13$ (m, $1 \mathrm{H}), 2.65$ (d, $J=4.70 \mathrm{~Hz}, 3 \mathrm{H}), 1.80$ - 2.02 (m, $2 \mathrm{H}), 1.56-1.76(\mathrm{~m}, 2 \mathrm{H})$.

\section{(S)-1-(4-((5-Methoxypyridin-3-yl)oxy)-5-(tetrahydro-2H-pyran-3-yl)pyridin-2-yl)-3-}

methylurea (22): The title compound (22) $(71.0 \mathrm{mg}, 0.20 \mathrm{mmol}, 18 \%$ yield) was the second 
peak off chiral column from the same chiral separation that isolated compound 21 . Stereochemistry was assigned arbitrarily. ESI (pos.) m/e: $359.1(\mathrm{M}+\mathrm{H})^{+} .{ }^{1} \mathrm{H} \mathrm{NMR}(400 \mathrm{MHz}$, DMSO- $\left.d_{6}\right) \delta$ ppm $9.02(\mathrm{~s}, 1 \mathrm{H}), 8.26(\mathrm{~d}, J=2.54 \mathrm{~Hz}, 1 \mathrm{H}), 8.09(\mathrm{~s}, 1 \mathrm{H}), 8.06(\mathrm{~d}, J=2.15 \mathrm{~Hz}, 1 \mathrm{H})$, 7.80 (br. s., $1 \mathrm{H}), 7.34$ (t, J=2.35 Hz, $1 \mathrm{H}), 6.76$ (s, $1 \mathrm{H}), 3.82$ - 3.96 (m, 5 H), 3.34 - 3.46 (m, 2 H), 3.03 - $3.14(\mathrm{~m}, 1 \mathrm{H}), 2.65(\mathrm{~d}, J=4.50 \mathrm{~Hz}, 3 \mathrm{H}), 1.76-2.00(\mathrm{~m}, 2 \mathrm{H}), 1.58-1.74(\mathrm{~m}, 2 \mathrm{H})$.<smiles>CNC(=O)Nc1cc(Oc2cncc(OC)c2)c(Br)cn1</smiles>

17a

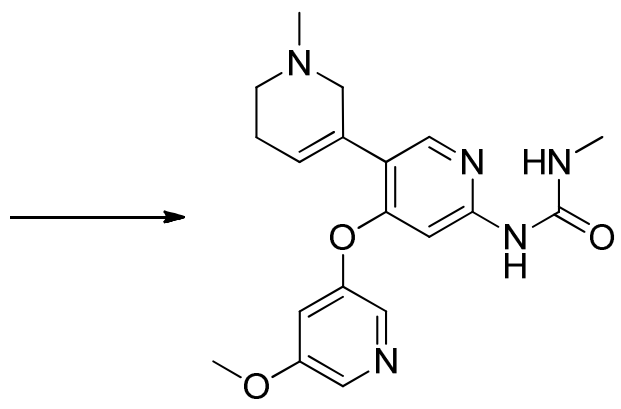

23a

\section{1-(4-((5-Methoxypyridin-3-yl)oxy)-1'-methyl-1',2',5',6'-tetrahydro-[3,3'-bipyridin]-6-yl)-3-}

methylurea (23a): The title compound (23a) was prepared from intermediate 17a and 1-methyl-5(4,4,5,5-tetramethyl-1,3,2-dioxaborolan-2-yl)-1,2,3,6-tetrahydropyridine following the same procedure of synthesizing compound 20 from 17a. ESI (pos.) m/e: $370.3(\mathrm{M}+\mathrm{H})^{+} .{ }^{1} \mathrm{H}$ NMR $(500 \mathrm{MHz}$, DMSO$\left.d_{6}\right) \delta$ ppm $9.11(\mathrm{~s}, 1 \mathrm{H}), 8.24(\mathrm{~d}, J=2.45 \mathrm{~Hz}, 1 \mathrm{H}), 8.02$ (d, J=2.20 Hz, $\left.1 \mathrm{H}\right), 8.01$ (s, $\left.1 \mathrm{H}\right), 7.72$ (br. s., $1 \mathrm{H}), 7.30$ (t, J=2.45 Hz, $1 \mathrm{H}), 6.84$ (s, $1 \mathrm{H}), 5.91$ (dt, J=3.73, $1.93 \mathrm{~Hz}, 1 \mathrm{H}), 3.85$ (s, $3 \mathrm{H}$ ), $3.12(\mathrm{~d}, J=1.96 \mathrm{~Hz}, 2 \mathrm{H}), 2.65(\mathrm{~d}, J=4.65 \mathrm{~Hz}, 3 \mathrm{H}), 2.43$ (t, J=5.75 Hz, $2 \mathrm{H}), 2.20-2.27$ (m, 5 H).<smiles>CNC(=O)Nc1cc(Oc2cncc(OC)c2)c(C2=CCCN(C)C2)cn1</smiles>

23a

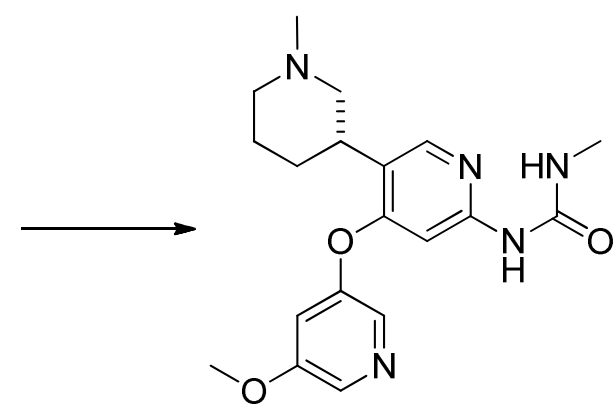

23

(S)-1-(4-((5-Methoxypyridin-3-yl)oxy)-5-(1-methylpiperidin-3-yl)pyridin-2-yl)-3-

methylurea (23): The title compound (23) was prepared following the same procedure as synthesizing compound 21. It was the second peak to elute from chiral column and also the more 
potent enantiomer of the two (the other one has a $2490 \mathrm{nM}$ GKA $\mathrm{EC}_{50}$ ). Stereochemistry was assigned arbitrarily. ESI (pos.) m/e: $372.5(\mathrm{M}+\mathrm{H})^{+} .{ }^{1} \mathrm{H}$ NMR $\left(500 \mathrm{MHz}, \mathrm{DMSO}-d_{6}\right) \delta \mathrm{ppm} 9.01$ $(1 \mathrm{H}, \mathrm{s}), 8.25(1 \mathrm{H}, \mathrm{d}, J=2.4 \mathrm{~Hz}), 8.10(1 \mathrm{H}, \mathrm{s}), 8.04(1 \mathrm{H}, \mathrm{d}, J=2.2 \mathrm{~Hz}), 7.84$ (1 H, br. s.), 7.32 (1 H, t, $J=2.4 \mathrm{~Hz}), 6.75(1 \mathrm{H}, \mathrm{s}), 3.85(3 \mathrm{H}, \mathrm{s}), 3.07(1 \mathrm{H}, \mathrm{tt}, J=10.7,3.4 \mathrm{~Hz}), 2.86(1 \mathrm{H}, \mathrm{d}, J=10.5$ Hz), $2.73(1 \mathrm{H}, \mathrm{d}, J=11.0 \mathrm{~Hz}), 2.65(3 \mathrm{H}, \mathrm{d}, J=4.6 \mathrm{~Hz}), 2.17(3 \mathrm{H}, \mathrm{s}), 1.99(1 \mathrm{H}, \mathrm{t}, J=10.6 \mathrm{~Hz})$, $1.92(1 \mathrm{H}, \mathrm{t}, J=10.1 \mathrm{~Hz}), 1.81(1 \mathrm{H}, \mathrm{d}, J=10.5 \mathrm{~Hz}), 1.67-1.74(1 \mathrm{H}, \mathrm{m}), 1.47-1.63(2 \mathrm{H}, \mathrm{m})$.

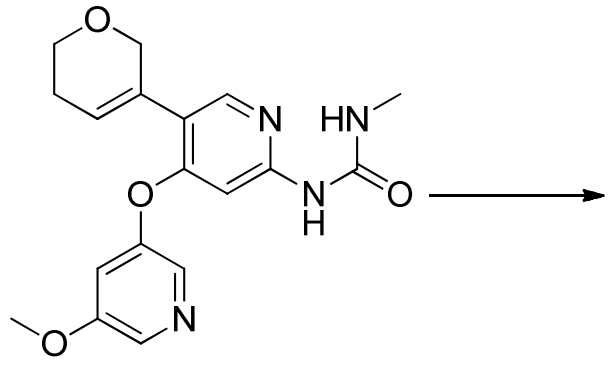

20

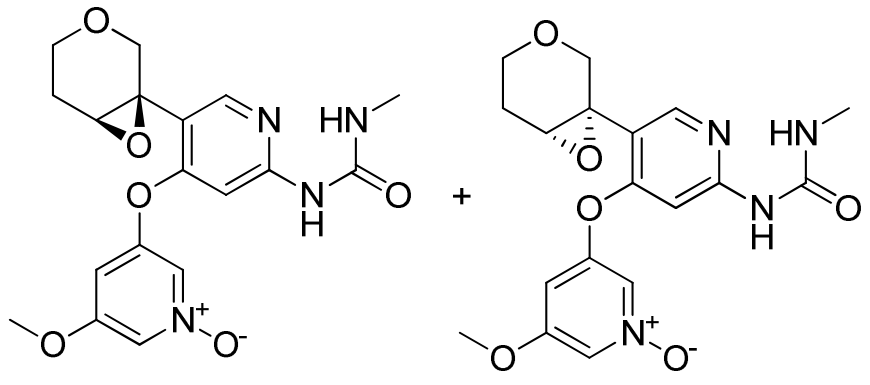

24a (racemic mixture of 2 compounds)

\section{3-((5-((1R,6S)-3,7-Dioxabicyclo[4.1.0]heptan-1-yl)-2-(3-methylureido)pyridin-4-yl)oxy)-5-} methoxypyridine 1-oxide and 3-((5-((1S,6R)-3,7-dioxabicyclo[4.1.0]heptan-1-yl)-2-(3methylureido)pyridin-4-yl)oxy)-5-methoxypyridine 1-oxide (24a): 1-(5-(5,6-dihydro-2Hpyran-3-yl)-4-((5-methoxypyridin-3-yl)oxy)pyridin-2-yl)-3-methylurea (20) (4.3 g, $12 \mathrm{mmol}$ ) was dissolved in DCM $(120 \mathrm{ml})$ and cooled to $0{ }^{\circ} \mathrm{C}$. 3-chlorobenzoperoxoic acid $(10 \mathrm{~g}, 60$ mmol) was then added and the reaction mixture was allowed to warm to ambient temperature over 1.5 hours. The reaction was then diluted with DCM $(250 \mathrm{~mL})$ and washed with $2 \mathrm{M}$ sodium carbonate solution $(2 \times 100 \mathrm{~mL})$. The combined aqueous layers were back extracted with $10 \%$ $\mathrm{MeOH} / \mathrm{DCM}(1 \times 100 \mathrm{~mL})$. The combined organic layers were dried over magnesium sulfate and the filtrate was concentrated to give the crude title compound (24a) $(4.0 \mathrm{~g}, 10 \mathrm{mmol}, 86 \%$ yield) that was used directly in the next reaction.

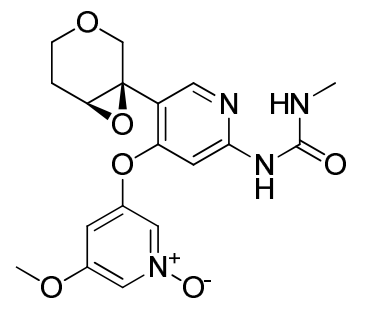

$24 a$
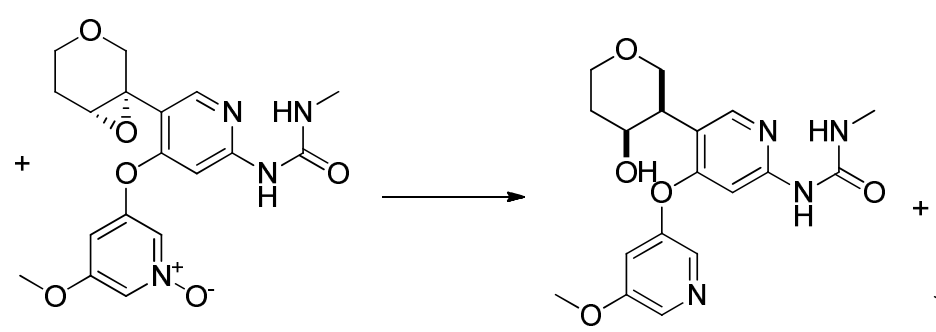

24 (mixture of 2 compounds) 
1-(5-((3R,4S)-4-hydroxytetrahydro-2H-pyran-3-yl)-4-((5-methoxypyridin-3-yl)oxy)pyridin2-yl)-3-methylurea and 1-(5-((3S,4R)-4-hydroxytetrahydro-2H-pyran-3-yl)-4-((5methoxypyridin-3-yl)oxy)pyridin-2-yl)-3-methylurea $\quad(24): \quad 3-((5-((1 \mathrm{R}, 6 \mathrm{~S})-3,7-$ dioxabicyclo[4.1.0]heptan-1-yl)-2-(3-methylureido)pyridin-4-yl)oxy)-5-methoxypyridine 1oxide and 3-((5-((1S,6R)-3,7-dioxabicyclo[4.1.0]heptan-1-yl)-2-(3-methylureido)pyridin-4yl)oxy)-5-methoxypyridine 1-oxide (24a) (3.0 g, $7.7 \mathrm{mmol})$ was dissolved in methanol (100 ml) and triethylamine $(11 \mathrm{ml}, 77 \mathrm{mmol})$. Palladium $(10 \% \mathrm{Pd} / \mathrm{C})$ dry $(14 \mathrm{~g}, 130 \mathrm{mmol})$ was added. The reaction mixture was then flushed with hydrogen and stirred at 500 psi for 36 hours. The reaction was then flushed with nitrogen and then diluted with dichloromethane and methanol and filtered over a pad of diatomaceous earth. The filtrate was washed with DCM and $\mathrm{MeOH}$ and concentrated. The residue was purified by medium pressure chromatography (silica, gradient 3 to $10 \% \mathrm{MeOH} / \mathrm{DCM})$ to give a racemic mixture of the title compound (24) $(780 \mathrm{mg}, 2.1 \mathrm{mmol}$, 27\% yield). ESI (pos.) m/e: $375.2(\mathrm{M}+\mathrm{H})^{+} .{ }^{1} \mathrm{H}$ NMR (400 MHz, $\left.\mathrm{CDCl}_{3}\right) \delta$ ppm 8.97 (br. s., $\left.1 \mathrm{H}\right)$, $8.76(\mathrm{~s}, 1 \mathrm{H}), 8.09(\mathrm{~d}, J=2.54 \mathrm{~Hz}, 1 \mathrm{H}), 8.07$ (s, $1 \mathrm{H}), 7.85-7.89(\mathrm{~m}, 1 \mathrm{H}), 6.93$ (t, J=2.45 Hz, 1 H), $6.16(\mathrm{~s}, 1 \mathrm{H}), 4.25-4.33(\mathrm{~m}, 1 \mathrm{H}), 4.19$ (t, J=10.66 Hz, $1 \mathrm{H}), 3.92$ - 4.00 (m, $1 \mathrm{H}), 3.83$ (s, 3 H), $3.78(\mathrm{~m}, J=11.15,3.91 \mathrm{~Hz}, 2 \mathrm{H}), 3.40$ - 3.55 (m, 1 H), 2.80 (d, J=4.70 Hz, $3 \mathrm{H}), 1.95$ - 2.09 (m, $1 \mathrm{H}), 1.71-1.90(\mathrm{~m}, 1 \mathrm{H})$.

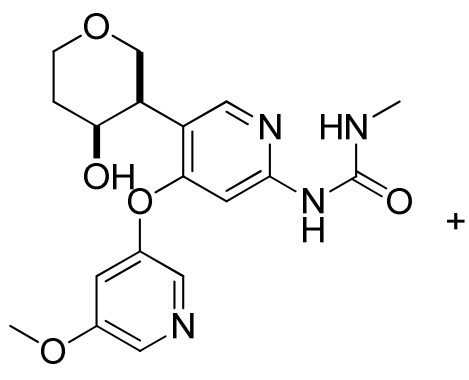

24

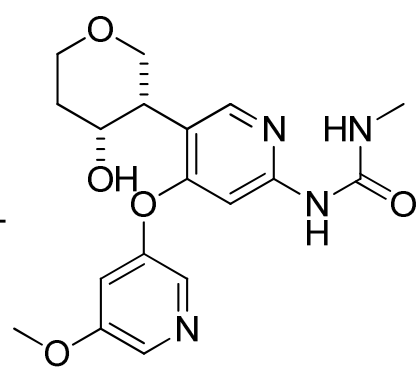

(2)
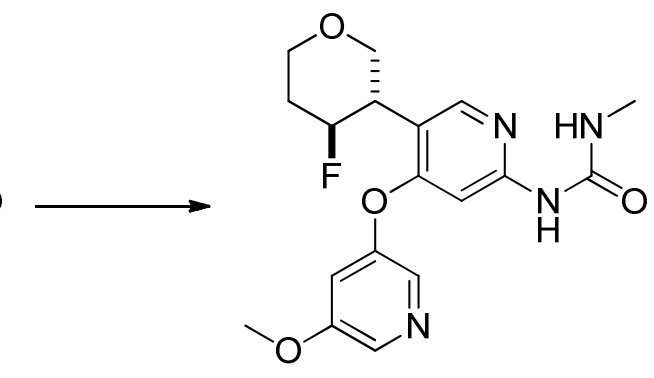

25

1-(5-((3S,4S)-4-Fluorotetrahydro-2H-pyran-3-yl)-4-((5-methoxypyridin-3-yl)oxy)pyridin-2yl)-3-methylurea $\quad$ (25): $\quad 1-(5-((3 R, 4 S)-4$-hydroxytetrahydro-2H-pyran-3-yl)-4-((5methoxypyridin-3-yl)oxy)pyridin-2-yl)-3-methylurea and 1-(5-((3S,4R)-4-hydroxytetrahydro2H-pyran-3-yl)-4-((5-methoxypyridin-3-yl)oxy)pyridin-2-yl)-3-methylurea (24) (500 mg, 1.30 mmol) was dissolved in DCM $(13.0 \mathrm{ml})$ and cooled to $-78{ }^{\circ} \mathrm{C}$. Deoxofluor ${ }^{\mathrm{TM}}(0.27 \mathrm{ml}, 1.50$ mmol) was added dropwise and the reaction mixture was allowed to warm to $-40{ }^{\circ} \mathrm{C}$ over a 
period of 1.5 hours. The reaction was not complete, so the mixture was recooled to $-78{ }^{\circ} \mathrm{C}$ and another aliquot of Deoxofluor ${ }^{\mathrm{TM}}(0.27 \mathrm{ml}, 1.50 \mathrm{mmol})$ was added. The reaction mixture was stirred at $-78{ }^{\circ} \mathrm{C}$ for an additional 30 minutes and the reaction was quenched with the addition of saturated sodium bicarbonate solution. The mixture was extracted with DCM $(2 \times 40 \mathrm{ml})$. The combined organic layers were then dried over magnesium sulfate and the residue was purified by medium pressure chromatography (silica, gradient 3 to $7.5 \% \mathrm{MeOH} / \mathrm{DCM}$ ) to give impure desired product which contained trans and cis isomers with trans isomers being major. The material was further purified by supercritical fluid chromatography to obtain pure enantiomers in three stages. Stage 1: 250x30mm AD column with $36 \mathrm{~mL} / \mathrm{min}$ EtOH +(20 mM Ammonia $)+84$ $\mathrm{g} / \mathrm{min} \mathrm{CO}_{2}$ on Thar $200 \mathrm{SFC}$. Outlet pressure $=100$ bar; Temp. $=20 \mathrm{C} ;$ Wavelength $=215 \mathrm{~nm}$. Using $1.0 \mathrm{~mL}$ injections of $290 \mathrm{mg} / 25 \mathrm{~mL}(11.6 \mathrm{mg} / \mathrm{mL})$ sample solution in EtOH, i.e. 11.6 $\mathrm{mg}$ /injection. Runtime $=13 \mathrm{~min}$, Cycle time $=9 \mathrm{~min}$; Stage 2: 250x30mm IC column with 54 $\mathrm{mL} / \mathrm{min} \mathrm{MeOH}+(20 \mathrm{mM}$ Ammonia $)+66 \mathrm{~g} / \mathrm{min} \mathrm{CO}_{2}$ on Thar $200 \mathrm{SFC}$. Outlet pressure $=100$ bar; Temp. $=26{ }^{\circ} \mathrm{C}$; Wavelength $=215 \mathrm{~nm}$. Using $4.0 \mathrm{~mL}$ injections of $100 \mathrm{mg} / 20 \mathrm{~mL}(5$ $\mathrm{mg} / \mathrm{mL}$ ) sample solution in $\mathrm{MeOH}$, i.e. $20 \mathrm{mg}$ /injection. Runtime = $15 \mathrm{~min}$, Cycle time = $9 \mathrm{~min}$; Stage 3: 250x30mm AD column with $36 \mathrm{~mL} / \mathrm{min} \mathrm{MeOH}+(20 \mathrm{mM} \mathrm{Ammonia})+84 \mathrm{~g} / \mathrm{min}^{\mathrm{CO}_{2}}$ on Thar 200 SFC. Outlet pressure $=100$ bar; Temp. $=26{ }^{\circ} \mathrm{C}$; Wavelength $=215 \mathrm{~nm}$. Using 3.0 $\mathrm{mL}$ injections of $\sim 60 \mathrm{mg} / 15 \mathrm{~mL}(4 \mathrm{mg} / \mathrm{mL})$ sample solution in $\mathrm{MeOH}$, i.e. $12 \mathrm{mg} /$ injection. Runtime $=16 \mathrm{~min}$, Cycle time $=8 \mathrm{~min}$. The title compound (25) was one of the trans isomers and was the first peak off column at Stage 2 separation ( $34 \mathrm{mg}, 0.088 \mathrm{mmol}, 6.8 \%$ yield). The relative stereochemistry was confirmed to be trans by NMR but absolute stereochemistry was arbitrarily assigned. ESI (pos.) m/e: $377.1(\mathrm{M}+\mathrm{H}){ }^{+} .{ }^{1} \mathrm{H} \mathrm{NMR}\left(400 \mathrm{MHz}, \mathrm{CDCl}_{3}\right) \delta$ ppm $9.23(\mathrm{~s}, 1$ H), 9.05 (br. s., $1 \mathrm{H}), 8.22$ (d, J=2.0 Hz, $1 \mathrm{H}), 8.11$ (s, $1 \mathrm{H}), 8.07$ (d, J=1.8 Hz, $1 \mathrm{H}), 6.95$ (t, $J=2.2 \mathrm{~Hz}, 1 \mathrm{H}), 6.20$ (s, $1 \mathrm{H}), 4.82$ - 5.18 (m, $1 \mathrm{H}), 3.98$ - 4.23 (m, $2 \mathrm{H}), 3.86$ (3 H, s), 3.52 - 3.65 (m, 2 H), 3.36 (qd, $J=9.3,4.5$ Hz, 1 H), 2.77 (d, $J=4.7$ Hz, 3 H), 2.08 - 2.32 (m, 1 H), 1.73 - 2.05 $(\mathrm{m}, 1 \mathrm{H})$. 


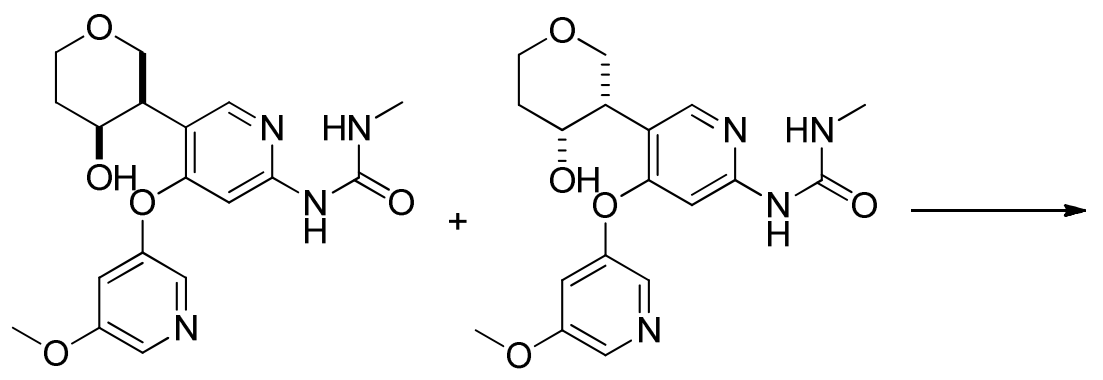

24

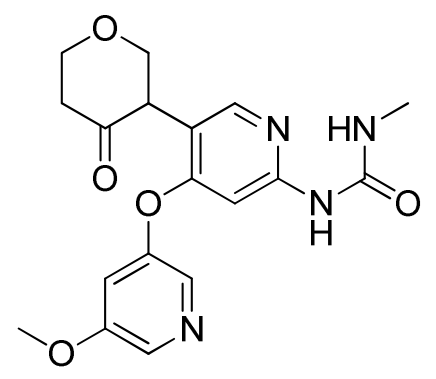

26a

\section{1-(4-((5-methoxypyridin-3-yl)oxy)-5-(4-oxotetrahydro-2H-pyran-3-yl)pyridin-2-yl)-3-}

methylurea (26a): 1-(5-((3R,4S)-4-hydroxytetrahydro-2H-pyran-3-yl)-4-((5-methoxypyridin-3yl)oxy)pyridin-2-yl)-3-methylurea and 1-(5-((3S,4R)-4-hydroxytetrahydro-2H-pyran-3-yl)-4-((5methoxypyridin-3-yl)oxy)pyridin-2-yl)-3-methylurea (24) (160 mg, $0.43 \mathrm{mmol}$ ) was dissolved in DCM $(5.0 \mathrm{ml})$ and cooled to $0{ }^{\circ} \mathrm{C}$. Dess-martin periodinane $(270 \mathrm{mg}, 0.64 \mathrm{mmol})$ was added and the reaction mixture was allowed to warm to room temperature over two hours. The reaction mixture was then diluted with DCM and washed with $1: 1$ saturated $\mathrm{Na}_{2} \mathrm{~S}_{2} \mathrm{O}_{3}$ : water solution, saturated sodium bicarbonate solution and then dried over magnesium sulfate. The filtrate was concentrated and the residue was purified by medium pressure chromatography (silica gel, gradient 0 to $7.5 \% \mathrm{MeOH} / \mathrm{DCM})$ to give the racemic title compound (26a) (112 $\mathrm{mg}, 70.0 \%$ yield) as a racemate. ESI (pos.) m/e: $373.1(\mathrm{M}+\mathrm{H})^{+} .{ }^{1} \mathrm{H}$ NMR $\left(400 \mathrm{MHz}, \mathrm{CDCl}_{3}\right) \delta \mathrm{ppm} 9.22(\mathrm{~s}$, $1 \mathrm{H}), 8.94$ (br. s., $1 \mathrm{H}), 8.21$ (d, $J=2.54 \mathrm{~Hz}, 1 \mathrm{H}), 8.06$ (d, $J=2.35 \mathrm{~Hz}, 1 \mathrm{H}), 7.87$ (s, $1 \mathrm{H}), 6.97$ (t, $J=2.45 \mathrm{~Hz}, 1 \mathrm{H}), 6.22(\mathrm{~s}, 1 \mathrm{H}), 4.27$ - $4.39(\mathrm{~m}, 2 \mathrm{H}), 3.94$ - 4.03 (m, $2 \mathrm{H}), 3.81$ - 3.88 (m, $4 \mathrm{H})$, $2.72-2.84(\mathrm{~m}, 4 \mathrm{H}), 2.50-2.57(\mathrm{~m}, 1 \mathrm{H})$.<smiles>CNC(=O)Nc1cc(Oc2cncc(OC)c2)c(C2COCCC2=O)cn1</smiles>

26a

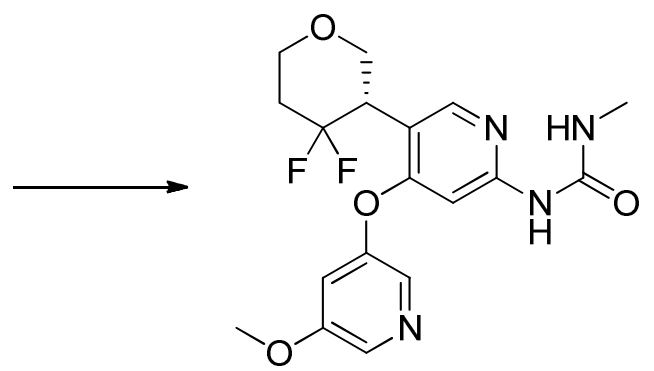

26

(S)-1-(5-(4,4-difluorotetrahydro-2H-pyran-3-yl)-4-((5-methoxypyridin-3-yl)oxy)pyridin-2-

yl)-3-methylurea (26): Racemic 1-(4-((5-methoxypyridin-3-yl)oxy)-5-(4-oxotetrahydro-2Hpyran-3-yl)pyridin-2-yl)-3-methylurea (26a) (160 mg, $0.42 \mathrm{mmol})$ was dissolved in DCM (7.00 
$\mathrm{ml})$ and cooled to $0{ }^{\circ} \mathrm{C}$. To the solution was added Deoxofluor ${ }^{\mathrm{TM}}(0.30 \mathrm{ml}, 1.60 \mathrm{mmol})$ and the solution was allowed to warm to ambient temperature over a period of 1.5 hours. Another aliquot of Deoxofluor $^{\mathrm{TM}}(0.28 \mathrm{ml}, 1.50 \mathrm{mmol})$ was added and the reaction mixture was stirred for an additional 1.5 hours. The reaction was quenched with saturated sodium bicarbonate and extracted with dichloromethane $(2 \times 30 \mathrm{~mL})$. The combined organic layers were then dried over magnesium sulfate. The residue was purified by medium pressure chromatography (silica, gradient 0 to $10 \% \mathrm{MeOH} / \mathrm{DCM}$ ) to give the racemic difluoro compound with impurity. This mixture was then purified by reverse-phase preparative HPLC using a Phenomenex Luna column, 10 micron, $\mathrm{C} 8(2), 100 \AA, 150 \times 30 \mathrm{~mm}, 0.1 \%$ TFA in $\mathrm{CH}_{3} \mathrm{CN} / \mathrm{H}_{2} \mathrm{O}$, gradient $10-25 \%$ to 95\% over 25 min to provide the TFA salt of the desired racemic compound. The TFA salt was then free based by eluting through an SCX column using 0 to $2 \mathrm{M}$ ammonia in $\mathrm{MeOH}$ as eluent to provide $9.0 \mathrm{mg}(0.02 \mathrm{mmol}, 6.0 \%$ yield $)$ of the racemate. $6 \mathrm{mg}$ of the racemate was further purified by supercritical fluid chromatography Separation condition: 150mm x $21 \mathrm{~mm} \mathrm{OZ}$ column with $25 \mathrm{~mL} / \mathrm{min} \mathrm{MeOH}+\left(20 \mathrm{mM} \mathrm{NH}_{3}\right)+46 \mathrm{~g} / \mathrm{min} \mathrm{CO}_{2}$ on Thar $80 \mathrm{SFC}$. Outlet pressure $=100$ bar; Temp. $=25 \mathrm{C}$; Wavelength $=215 \mathrm{~nm}$. Used $0.5 \mathrm{~mL}$ injections of $6 \mathrm{mg} / 3 \mathrm{~mL}$ $(2.0 \mathrm{mg} / \mathrm{mL})$ sample solution in $\mathrm{MeOH}$, i.e. $1.0 \mathrm{mg} /$ injection. Run time $=6.0 \mathrm{~min}$, cycle time 3.0 min. The title compound (26) (3.0 mg, $0.079 \mathrm{mmol}, 4.9 \%$ yield) was the second peak off chiral column. ESI (pos.) m/e: $395.1(\mathrm{M}+\mathrm{H})^{+} .{ }^{1} \mathrm{HNMR}\left(400 \mathrm{MHz}, \mathrm{CDCl}_{3}\right) \delta$ ppm 9.08 (br. s., $\left.1 \mathrm{H}\right)$, $8.55(\mathrm{~s}, 1 \mathrm{H}), 8.23(\mathrm{~d}, J=2.3 \mathrm{~Hz}, 1 \mathrm{H}), 8.21$ (d, $J=1.0 \mathrm{~Hz}, 1 \mathrm{H}), 8.07$ (d, J=2.2, Hz, $1 \mathrm{H}), 6.94$ (t, $J=2.3 \mathrm{~Hz}, 1 \mathrm{H}), 6.12(\mathrm{~s}, 1 \mathrm{H}), 3.99-4.14(\mathrm{~m}, 2 \mathrm{H}), 3.87$ (s, $3 \mathrm{H}), 3.81$ (m, $3 \mathrm{H}), 2.82(\mathrm{~d}, J=4.7 \mathrm{~Hz}$, $3 \mathrm{H}), 2.06-2.25(\mathrm{~m}, 2 \mathrm{H})$. 
NMR data for compound 7:

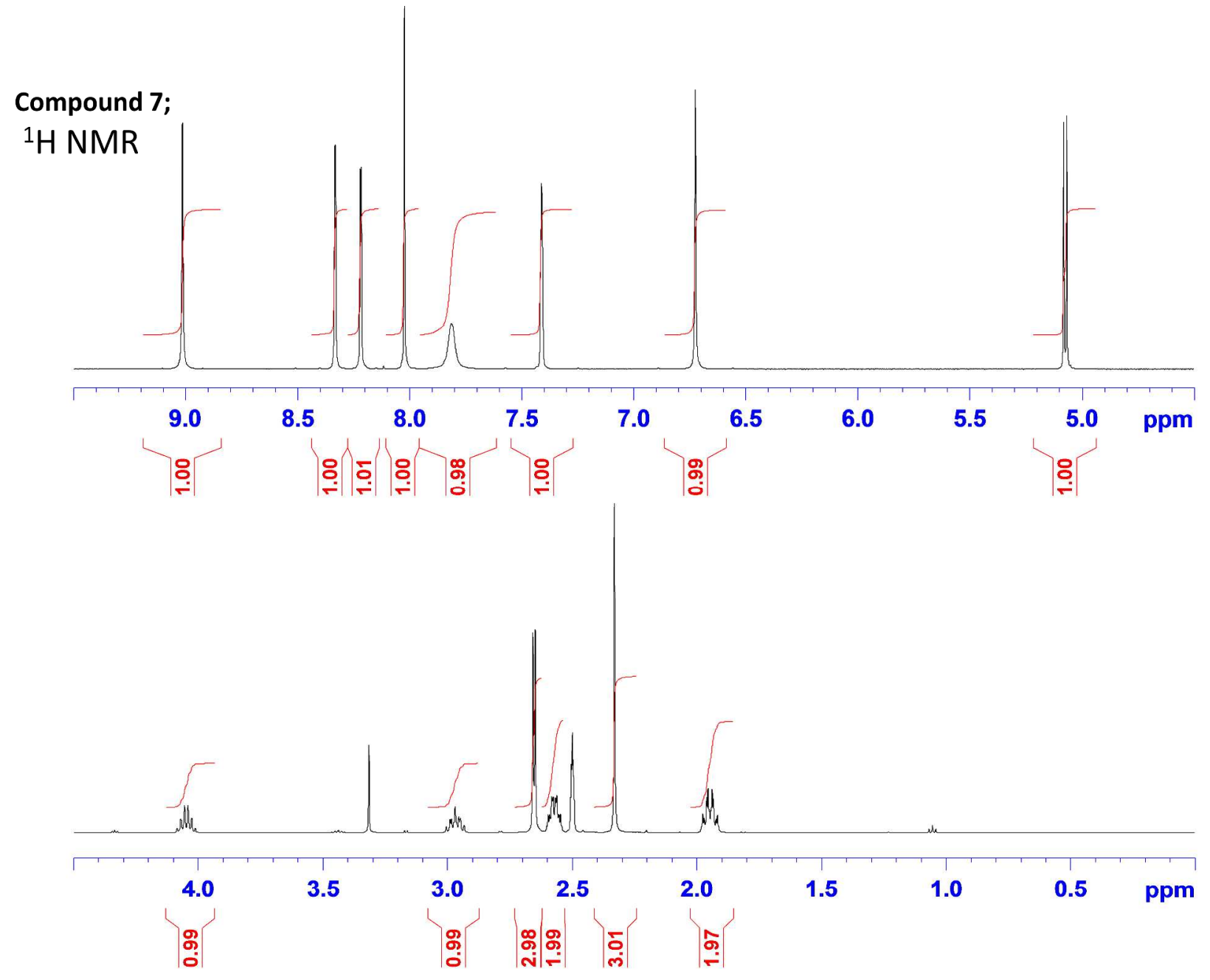




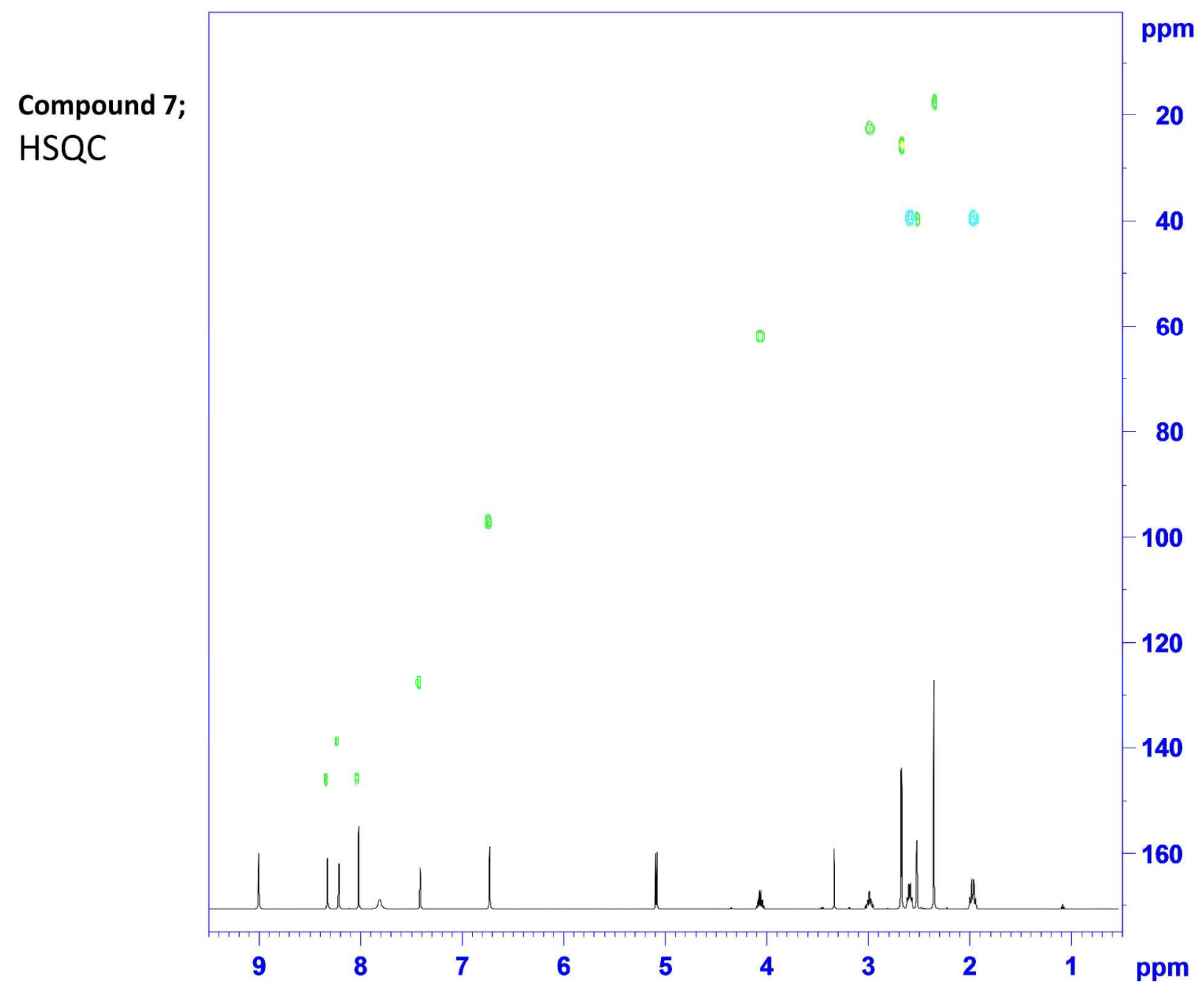




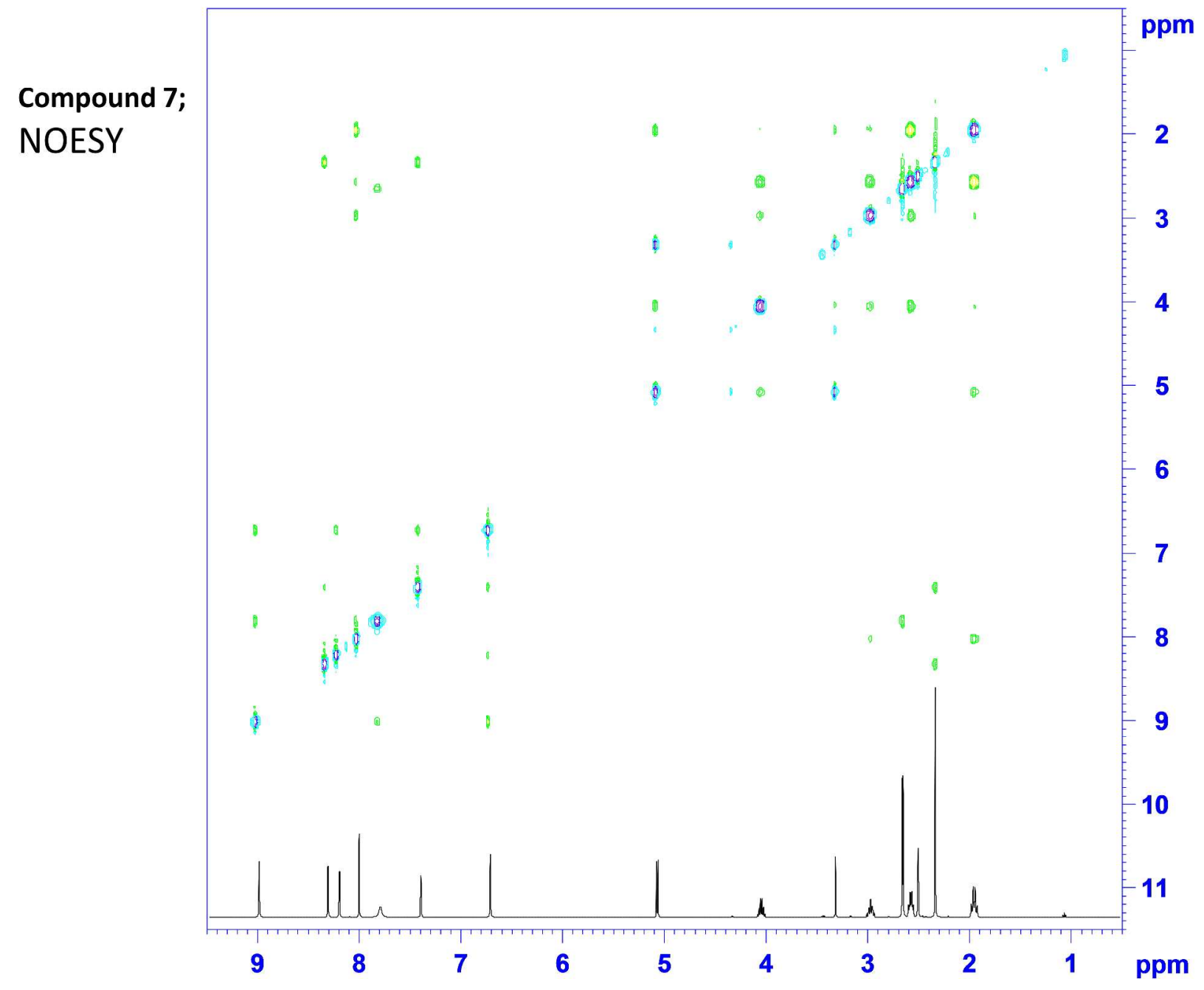




\section{Metabolic ID studies for compound 21}

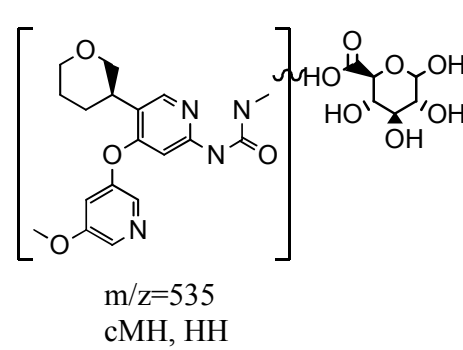

$\mathrm{HO}$

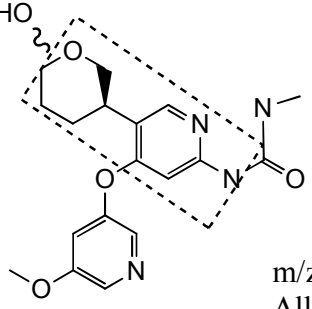

$\mathrm{m} / \mathrm{z}=375$ All species

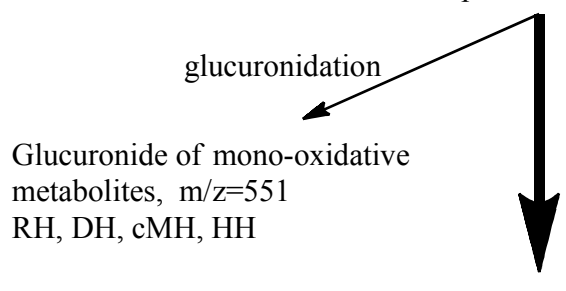

oxidation

\section{oxidation}<smiles></smiles>

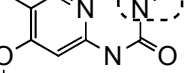

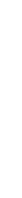

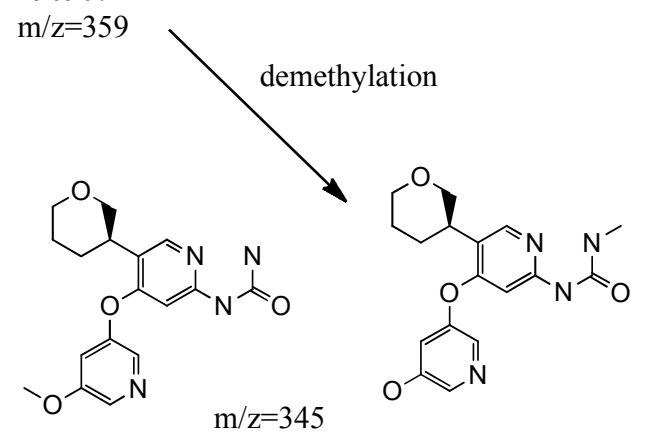

$\mathrm{MH}, \mathrm{RH}, \mathrm{DH}, \mathrm{HH}$

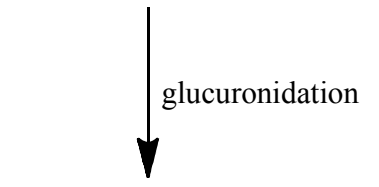

Glucuronide of demethylation metabolites, $\mathrm{m} / \mathrm{z}=521$ All species<smiles>CNC(=O)Nc1cc(Oc2cncc(OC)c2)c([C@H](CO)CCC(=O)O)cn1</smiles><smiles>CNC(=O)Nc1cc(Oc2cncc(OC)c2)c([C@H](CCCO)C(=O)O)cn1</smiles>

$\mathrm{m} / \mathrm{z}=391$

Major metabolite in all species

${ }^{i}$ Nicolaou, K. C., Li, Y., Uesaka, N., Koftis, T. V., Vyskocil, S., Ling, T., Govindasamy, M., Qian, W., Bernal, F. and Chen, D. Y.-K. (2003), Total Synthesis of the Proposed Azaspiracid-1 Structure, Part 1: Construction of the Enantiomerically Pure C1-C20, C21-C27, and C28-C40 Fragments. Angew. Chem. Int. Ed., 42: 3643-3648. 